Division of Geological \& Geophysical Surveys

PRELIMINARY INTERPRETIVE REPORT 2013-6

\title{
YUKON RIVER BRIDGE LANDSLIDE: \\ PRELIMINARY GEOLOGIC AND GEOTECHNICAL EVALUATION
}

by

Rich D. Koehler, Richard D. Reger, Karri R. Sicard, and Eleanor R. Spangler

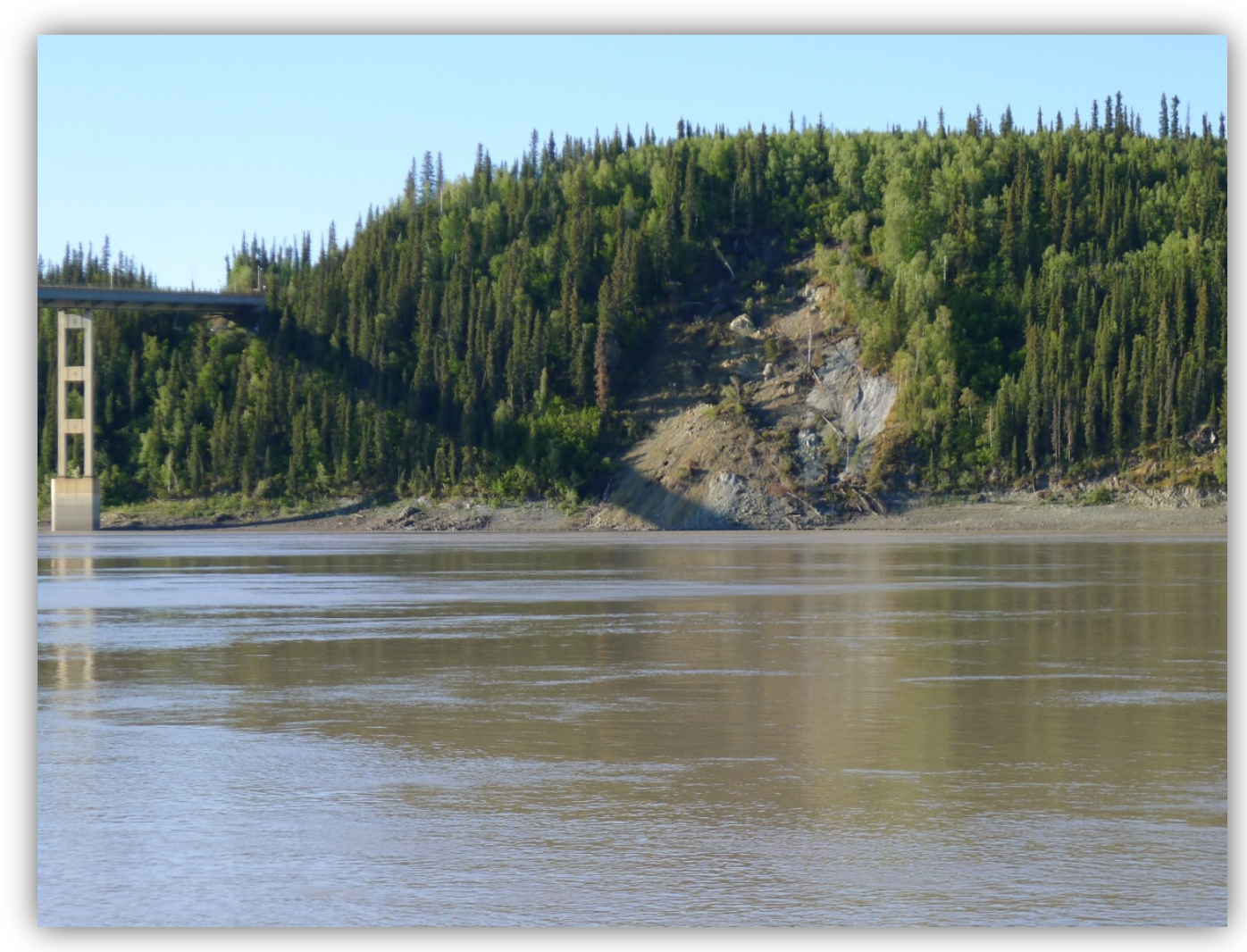

Yukon River bridge landslide viewed from the north bank of the Yukon River. Photo by Rich D. Koehler

October 2013

Released by

STATE OF ALASKA

DEPARTMENT OF NATURAL RESOURCES

Division of Geological \& Geophysical Surveys

3354 College Rd.

Fairbanks, Alaska 99709-3707

$\$ 7.00$ 



\section{CONTENTS}

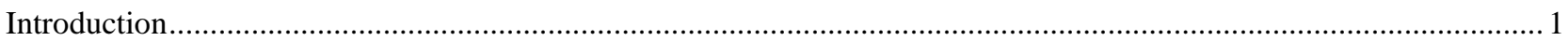

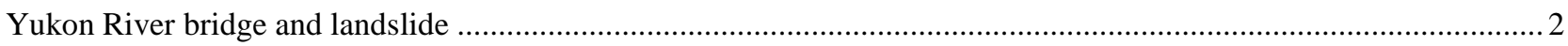

Regional geology and geomorphology of the Yukon River bridge vicinity ......................................................... 3

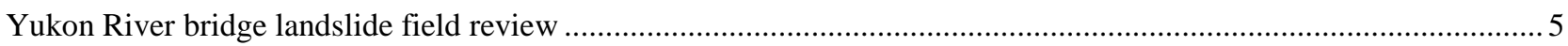

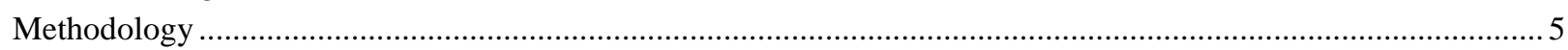

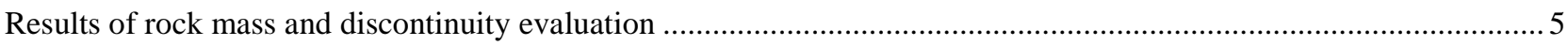

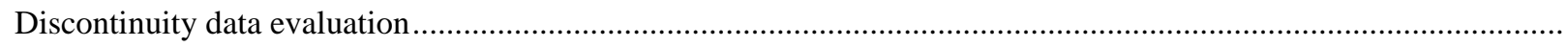

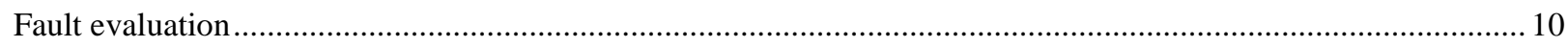

Results of slope and landslide geomorphology evaluation .............................................................................. 13

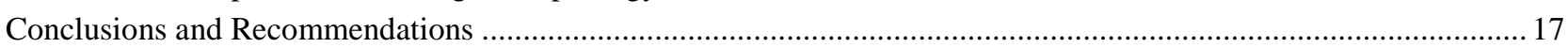

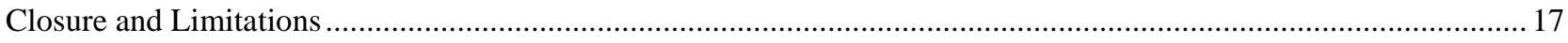

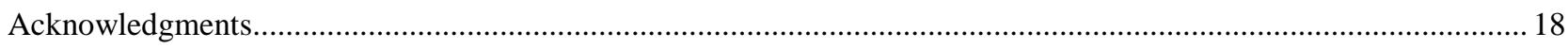

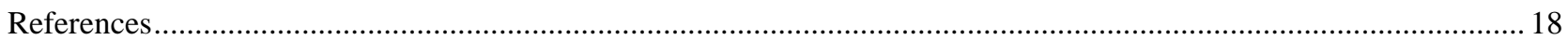

\section{TABLES}

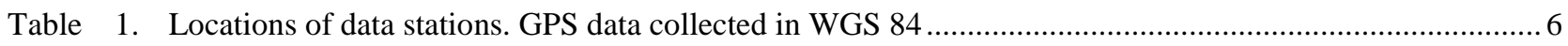

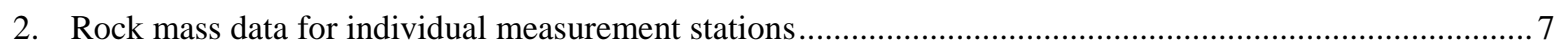

3. Characteristics of LiDAR-derived slope profiles evaluated for evidence of slope instability..................... 13

\section{FIGURES}

Figure 1. Topographic map of the Yukon River bridge vicinity.......................................................................... 1

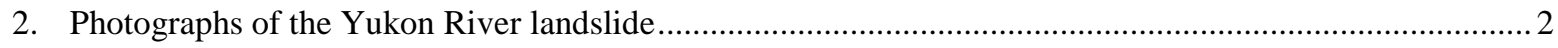

3. Geologic map of the site vicinity (from Weber and others, 1992) ........................................................... 4

4. Location of field stations and inferred bedrock contacts along the Yukon River bluff transect..................... 6

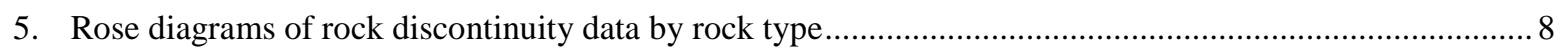

6. Rose diagrams of rock discontinuity data from each measurement station, and composite

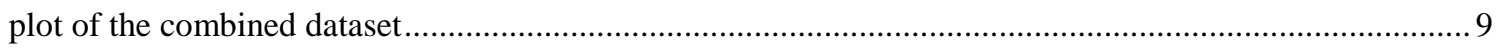

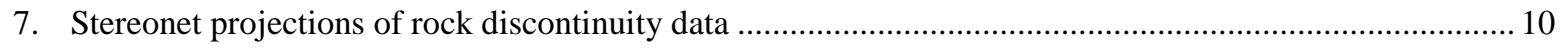

8. Site vicinity map, showing locations of topographic profiles ................................................................. 11

9. Topographic profiles A-H and $\mathrm{K}-\mathrm{V}$ across the southern bluff of the Yukon River in the

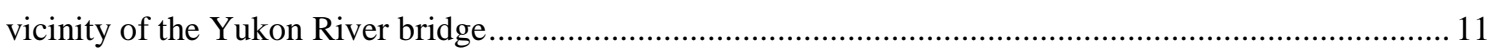

10. Geomorphic interpretation of the Yukon River bridge area, showing the 2012 landslide

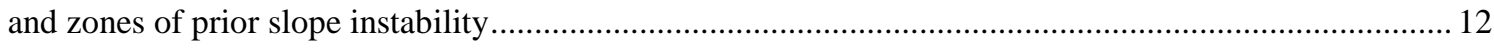

11. Pre- and post-landslide hillshade images derived from 2010 and 2013 LiDAR data................................. 14

12. Topographic profiles I and $\mathrm{J}$ across the Yukon River bridge landslide showing the

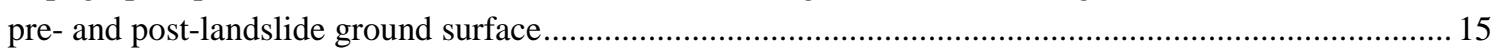

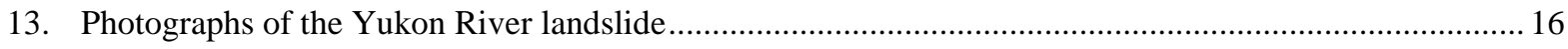

\section{APPENDICES}

Appendix $\quad$ A. Photographs of bedrock at rock discontinuity measurement stations ..............................................19

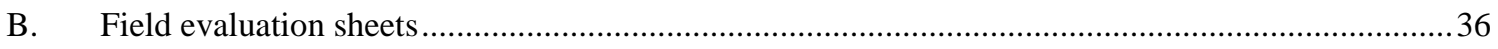





\title{
YUKON RIVER BRIDGE LANDSLIDE: PRELIMINARY GEOLOGIC AND GEOTECHNICAL EVALUATION
}

\author{
by Rich D. Koehler ${ }^{1}$, Richard D. Reger ${ }^{2}$, Karri R. Sicard ${ }^{3}$, and Eleanor R. Spangler ${ }^{3}$
}

\section{Introduction}

This report presents the findings of a geologic and geotechnical evaluation of a landslide at the Yukon River bridge, conducted by the State of Alaska, Division of Geological \& Geophysical Surveys (DGGS) through a reimbursable services agreement with the State of Alaska Department of Transportation \& Public Facilities (ADOT\&PF). The E.L. Patton Bridge spans the Yukon River at the Dalton Highway crossing approximately 90 miles northwest of Fairbanks, Alaska (fig. 1). The bridge is a vital link on the transportation corridor between Prudhoe Bay and Fairbanks and supports the trans-Alaska oil pipeline.

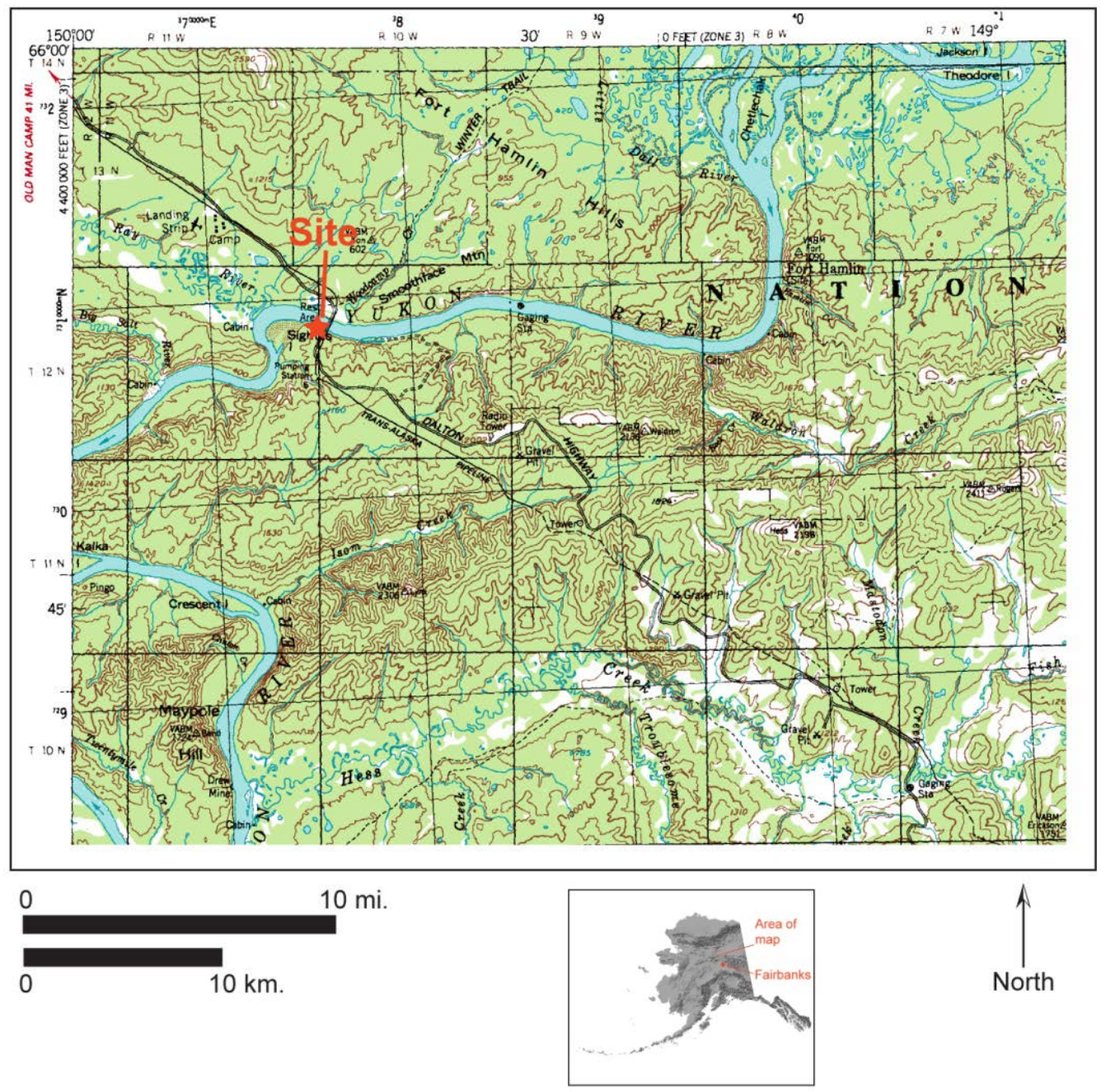

Figure 1. Topographic map of the Yukon River bridge vicinity. Location of landslide shown by red star.

\footnotetext{
${ }^{1}$ Alaska Division of Geological \& Geophysical Surveys, 3354 College Rd., Fairbanks, AK 99709-3707; email: rich.koehler@alaska.gov

${ }^{2}$ Reger's Geologic Consulting, PO Box 3326, Soldotna, AK 99669-3326

${ }^{3}$ Alaska Division of Geological \& Geophysical Surveys, 3354 College Rd., Fairbanks, AK 99709-3707.
} 
A.

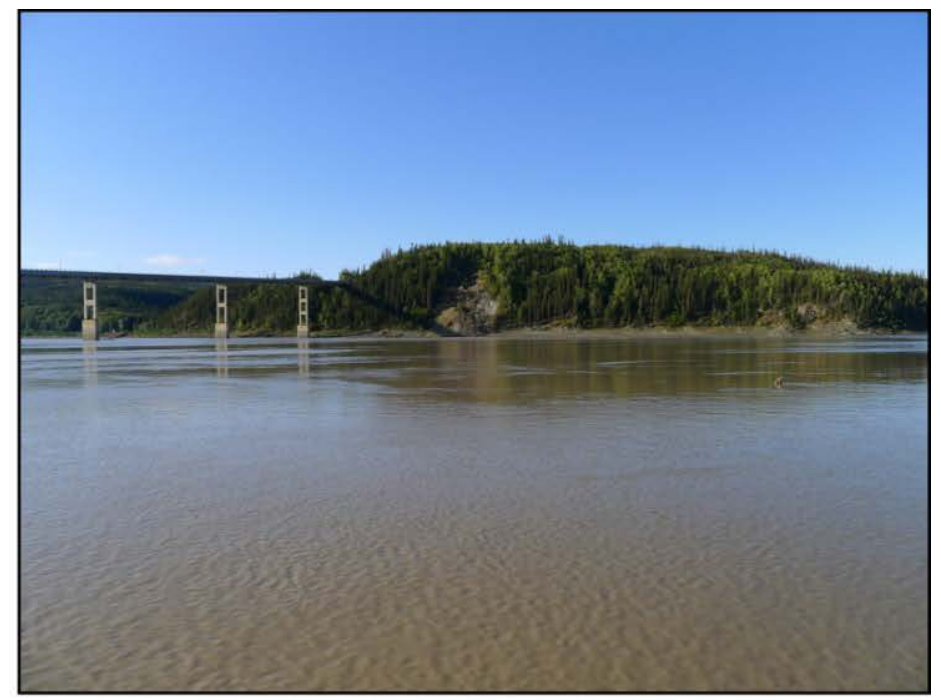

B.

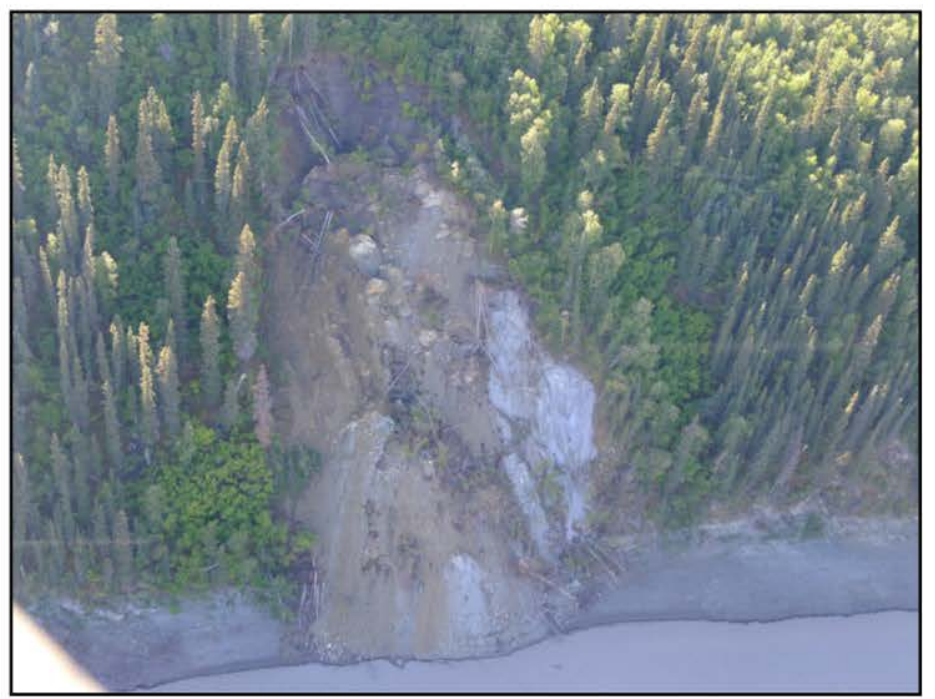

C.

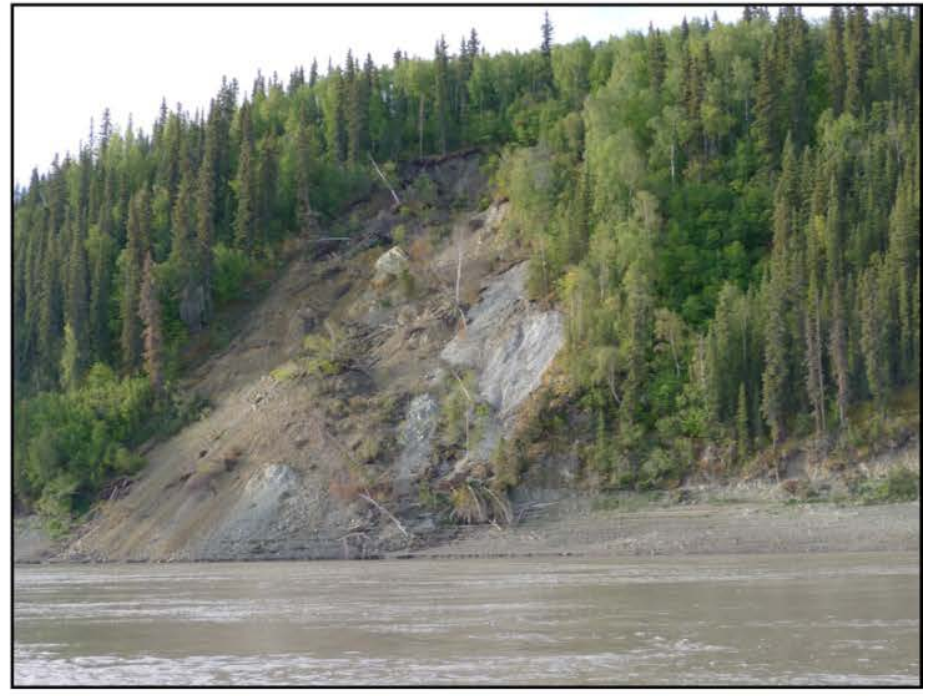

Figure 2. Photographs of the Yukon River landslide. A. View from the north bank of the river. B. Aerial view of slide from helicopter. C. Closer view of slide from the river.
The Yukon River bridge landslide occurred in fall 2012 between approximately 375 and 575 feet west of the bridge (fig. 2). Although there was no damage to the bridge foundation, the landslide's close proximity to the bridge and concerns over additional failures prompted multiple evaluations, including landslide documentation, drainage assessments, and geotechnical studies, among others. The main purpose of this study is to provide baseline geotechnical and geomorphic observations to supplement concurrent slope-stability analyses being conducted by ADOT\&PF, Alyeska Pipeline Service Company, and their consultants.

The following tasks are included in the scope of this evaluation:

- Examination of published geologic reports, LiDAR imagery, and geologic maps;

- Aerial reconnaissance of the bridge vicinity by helicopter on August 25, 2013;

- Ground reconnaissance along the base of the bluff below the bridge and around the landslide between August 26 and 29, 2013;

- Preliminary evaluation of rock strength and discontinuity data;

- Preliminary evaluation of principal stress orientations;

- Preliminary evaluation of slopes and landslide geomorphology;

- Preparation of this report.

\section{Yukon River bridge and landslide}

The E.L. Patton Bridge was originally built in 1974-1975 to facilitate construction of the Trans-Alaska Pipeline System (TAPS). Use and maintenance of the bridge and Dalton Highway were officially turned over to the State of Alaska in 1978. The bridge is a girder bridge design measuring 2,295 feet long and 30 feet wide with a timber deck that slopes upward about 200 feet from the north to the south bank of the river. It is supported by five main in-stream piers, and abutments on each bank. It remains the only bridge crossing of the Yukon River in Alaska. The Dalton Highway and the Trans-Alaska Pipeline System rely on the bridge to connect Fairbanks to 
the Prudhoe Bay oilfields, ensuring an uninterrupted corridor for the transportation of supplies and personnel. Any compromise to the bridge's integrity could potentially have immediate and severe consequences to the State's economy and environment.

Sometime during late fall 2012, a landslide occurred on the steep bluff above the south shore of the Yukon River between 375 and 575 feet downriver from the E.L. Patton Bridge (fig. 2). The slide originally was reported by Alyeska security on November 30, 2012. Subsequent field inspections conducted by Alyeska and ADOT\&PF on December 7, 2012, and January 18, 2013, determined that the slide may have been controlled by highly fractured and altered weak zones in the rock mass (Frank Wuttig, oral commun.). These weak zones were inferred to be related to a potential fault zone encountered during construction of bridge pier 4. Additionally, it was noted that the slide occurred in perennially frozen ground. Given the 2012 slope failure and the occurrence of potentially adverse ground conditions, it was recommended that additional slope monitoring and geotechnical investigations be undertaken. This report contributes to those ongoing investigations.

\section{Regional geology and geomorphology of the Yukon River bridge vicinity}

The Yukon River bridge landslide is located along the north-facing bluff of the Yukon River canyon directly west of the E.L. Patton Bridge, approximately 20 miles downstream from the southwestern margin of Yukon Flats (fig. 1). The Yukon River essentially marks the boundary between the Kokrine-Hodzana Highlands, the Rampart Trough, and the Yukon-Tanana Upland physiographic provinces (Wahrhaftig, 1965).

The regional geology of the vicinity of the site is shown in figure 3. Bedrock lithologies near the Yukon River bridge are primarily mapped as Mississippian-Triassic Rampart Group rocks, but minor Tertiary volcanic and sedimentary rocks are present to the southeast (Weber and others, 1992). The Rampart Group consists of a complex assemblage of tectonically deformed mafic igneous and sedimentary rocks. The mafic igneous rocks are intrusive and extrusive and range from aphanitic greenstone to coarse-grained diorite and gabbro, with very rare occurrences of ultramafic rock (Weber and others, 1992). These rocks locally include pillows, amygdules, and interbedded sedimentary rocks. Sedimentary rocks of the Rampart Group, defined by Weber and others (1992), consist of argillite, chert, graywacke, shale, and limestone. Shale units are typically dark gray to black, graphitic, calcareous, and fissile. Argillite and chert units are medium-light gray to greenish gray, locally banded, conglomeratic or brecciated. Graywacke metasandstones are greenish gray, fine to medium grained, and locally micaceous, feldspathic, quartzose, or calcareous. Minor limestone units are bluish gray, fine grained, and laminated. The Rampart Group may correspond to the Tozitna stratigraphic belt in the Livengood area to the south (Dover, 1994; Mertie, 1937; Jones and others, 1984).

In the upland south of the river, tributaries of the Yukon River are incised $\leq 1,700$ feet below ridge crests in rocks of the Rampart Group. Ridge crests are blanketed by 5-50 feet of frozen, locally ice-rich upland loess, and intervening lowlands and stream valleys contain thick, frozen, ice-rich loess and retransported silt (Kreig and Reger, 1982; Shur and others, 2010). These deposits are roughly equivalent to Quaternary loess and colluvium (Qlc) and Quaternary silt (Qsu) mapped by Weber and others (1992) (fig. 3). Through its canyon, the Yukon River winds past 800 - to 1,000-foot-high bedrock ridges that were steeply truncated by colossal middle to late Pleistocene outburst floods (Froese and others, 2003; Thorson and Dixon, 1983). At least 160 feet of frozen, finegrained fluvial and eolian sediments form a surface 200-300 feet above the modern river (Clement, 1999). That surface is modified by thermokarst processes, including formation and expansion of thermokarst pits and gullies, collapse of deep yedoma depressions, and local development of thaw-induced, retrogressive landslides in the river-cut silt bluffs. A pair of late Holocene fluvial terraces with sand and silt cover discontinuously flanks the modern river channel.

The Ray River lowland contains a thick, perennially frozen fill of ice-rich, fine-grained sediments that accumulated during massive late-Pleistocene outburst floods in a major slackwater basin just upriver of a hydraulic dam that formerly existed where the flooding Yukon River abruptly turned south and entered a narrow canyon (Thorson, 
1989). Northeast of the Ray River lowland the Fort Hamlin Hills, which are composed of Rampart Group that is weathered to depths $\geq 5$ feet, rise to elevations of 1,500 to 3,150 feet. Up to one foot of loess discontinuously covers bedrock and colluvium on upper slopes, and frozen, locally ice-rich loess and retransported silt reach thicknesses of $\geq 100$ feet on middle and lower slopes. Perennially frozen alluvial-colluvial fans coalesce at the mouths of stream drainages cut into the southern flank of the Fort Hamlin Hills, forming an ice-rich apron crossed by the TAPS and Dalton Highway routes.
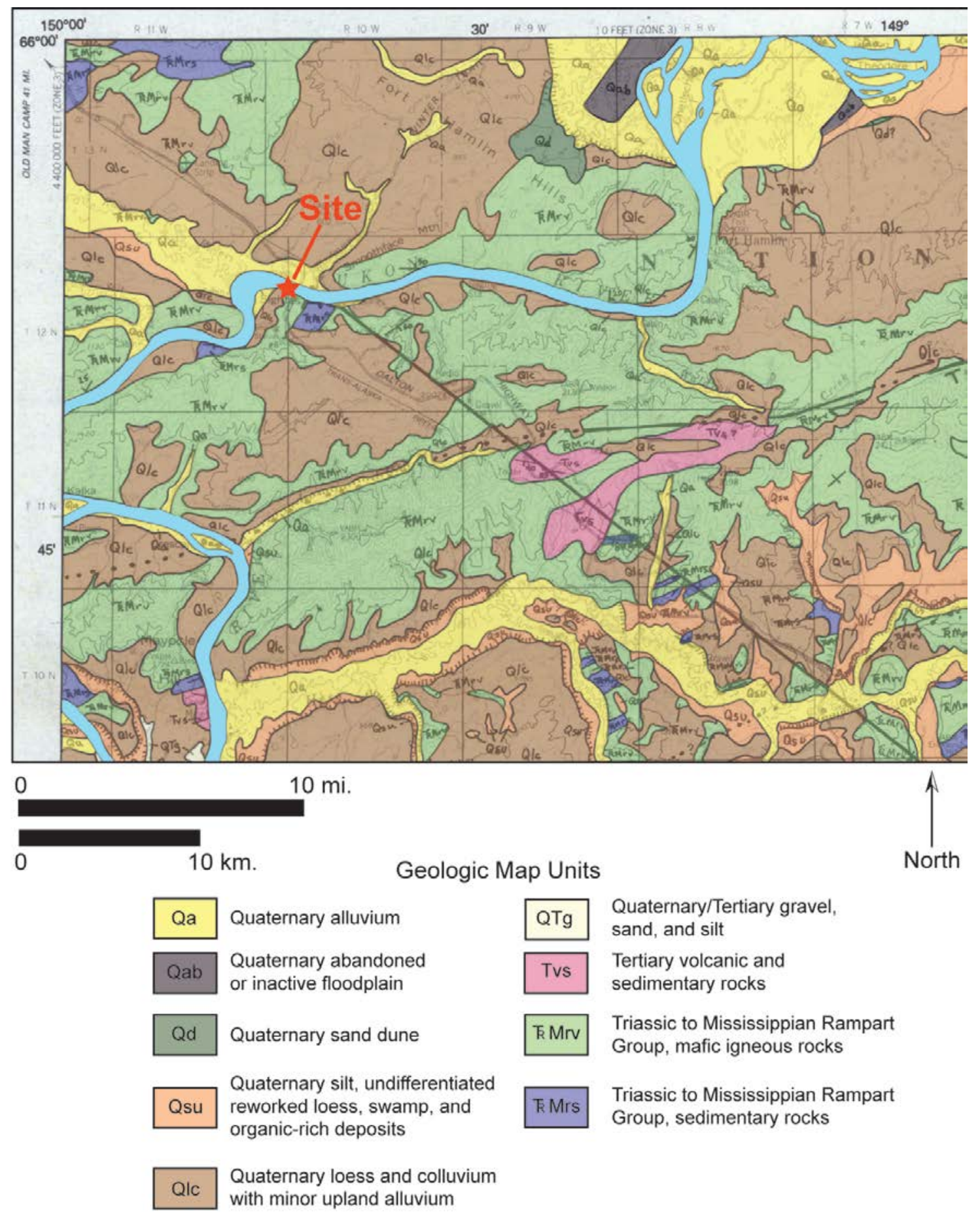
QTg Quaternary/Tertiary gravel, sand, and silt
Tvs Tertiary volcanic and sedimentary rocks
₹ Mrv Triassic to Mississippian Rampart Group, mafic igneous rocks Group, sedimentary rocks

Figure 3. Geologic map of the site vicinity from Weber and others (1992). Geologic units are colored to emphasize unit boundaries. Location of the Yukon River bridge landslide is shown by red star. 


\section{Yukon River bridge landslide field review}

Methodology

The Yukon River bridge landslide field review was performed August 25-29, 2013, by Rich Koehler, Karri Sicard, and Eleanor Spangler of DGGS and Richard “Dick” Reger of Reger's Geologic Consulting. A helicopter reconnaissance organized by Frank Wuttig of Alyeska Pipeline Services Company provided an overview of the landslide and general observations of the slope conditions upstream and downstream of the bridge. Robert Joseph of Stevens Village provided boat transportation to access the lower bluff and landslide area and to observe slopes along the south bluff upstream and downstream of the bridge.

Bedrock outcrops along the base of the Yukon River bluff were inspected for the presence of faults, fractures, shears or weathering zones, and/or other features that could provide information from which to infer subsurface conditions of bedrock farther upslope. Quantitative descriptions of rock mass and discontinuity data are based on the methodology of ISRM (1978). Rock mass and discontinuity survey data sheets from the Alaska Field Rock Classification and Structural Mapping Guide (ADOT\&PF, 2003) were used to record the field observations. Key rock characteristics that were documented include lithology, color, grain size, field compressive strength, rock mass fabric, block size, and state of weathering. Discontinuity surveys at each outcrop station include information on type of discontinuity, dip, dip direction, persistence, termination, aperture, nature of filling, strength of filling, surface roughness, surface shape, waviness, joint roughness coefficient, and presence of water. Detailed definitions for each of these parameters are provided in ADOT\&PF (2003). Discontinuity orientations were measured with a Brunton compass, using standard geologic field techniques.

The slope and landslide evaluation made use of both office and field techniques. Pre- and post-landslide LiDAR data collected by Hubbard and others (2011) and Alyeska Pipeline Service Company, respectively, were used to generate slope profiles and evaluate possible past slope failures. These two data sets were also used to compare the pre- and post-landslide ground surface. The combined LiDAR and field observations were used to quantitatively evaluate possible failure mechanisms for the 2012 landslide.

\section{Results of rock mass and discontinuity evaluation}

We evaluated rock strength and discontinuity characteristics along the base of the bluff and riverbank at 13 bedrock field stations distributed between approximately 850 feet east of the Yukon River bridge and approximately 1,150 feet west of the bridge (fig. 4). An additional zone of intensely sheared graywacke between stations 10 and 11 was mostly covered by beach gravels and boulders, and thus not described in the field as a separate station. Observations from this zone are provided in the following discussion. Photographs documenting bedrock features at each outcrop station along the base of the bluff are included in Appendix A. An additional observation station was located at the crest of the landslide. The location of each station and approximate bedrock contacts are shown on a strip map of the transect (fig. 4). GPS coordinates for each station are listed in Table 1. Detailed observations and inventory of rock discontinuity measurements are recorded in the field evaluation sheets in Appendix B.

Bedrock lithologies along the base of the Yukon River bluff consist of diorite, gabbro, graywacke metasandstones, greenstone, metabasalt, and chert (fig. 4). Table 2 shows rock-mass information for each bedrock field station. In general, the rock mass is characterized as strong to very strong rock that is fresh to slightly weathered with local zones of moderate weathering. The freshness of the rock is likely a reflection of ice scour and limited exposure to surface conditions (i.e., $<15,000$ years.). Limited inspection of the roadcut at the south abutment of the bridge indicates that the rock may grade upslope to a more weathered condition (moderately to highly weathered?); however, this outcrop was not studied in detail. The rock character along the base of the bluff is generally blocky (small to medium in scale) with discontinuous zones of very small shattered blocks and closely fractured to crushed zones. The graywacke metasandstone is the only rock type with a discernible fabric, includ- 
ing slightly metamorphosed and deformed beds. However, the deformed bedding is irregularly folded and does not have a consistent orientation.

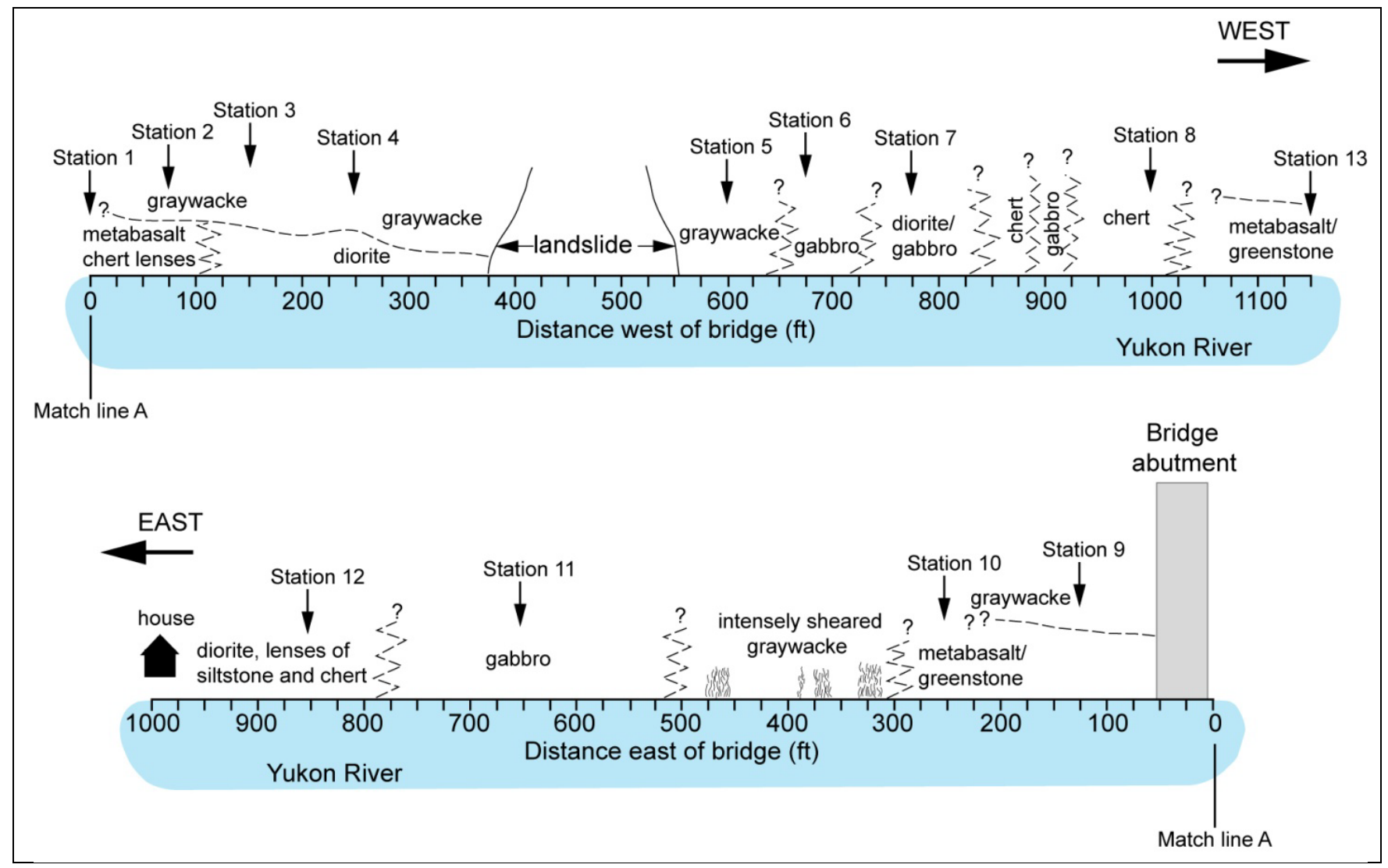

Figure 4. Location of field stations and inferred bedrock contacts along the Yukon River bluff transect. Area west of the bridge is shown at top; area east of the bridge is at bottom.

Table 1. Locations of data stations. GPS data collected in WGS 84.

\begin{tabular}{cclc}
\hline $\begin{array}{c}\text { Station } \\
\text { number }\end{array}$ & $\begin{array}{c}\text { GPS } \\
\text { point }\end{array}$ & \multicolumn{1}{c}{ Latitude } & Longitude \\
\hline 1 & 5 & 65.87386703 & -149.724802 \\
2 & 6 & 65.87396703 & -149.725185 \\
3 & 7 & 65.87400097 & -149.725785 \\
4 (a and b) & 8 & 65.874034 & -149.725752 \\
5 (a and b) & 9 & 65.87451696 & -149.728152 \\
6 & 10 & 65.87496699 & -149.728452 \\
7 & 11 & 65.87491703 & -149.729318 \\
8 & 12 & 65.87515097 & -149.730452 \\
9 & 13 & 65.87381699 & -149.724118 \\
10 & 14 & 65.87370099 & -149.723002 \\
11 & 15 & 65.87271703 & -149.721452 \\
12 & 16 & 65.87230104 & -149.720385 \\
13 & 18 & 65.87573804 & -149.732431 \\
\hline
\end{tabular}


Table 2. Rock mass data for individual measurement stations.

\begin{tabular}{|c|c|c|c|c|c|c|c|c|}
\hline Station & Lithology & Color & $\begin{array}{l}\text { Grain } \\
\text { size }\end{array}$ & $\begin{array}{c}\text { Compressive } \\
\text { strength }\end{array}$ & $\begin{array}{c}\text { State of } \\
\text { weathering }\end{array}$ & Fabric & $\begin{array}{l}\text { Block } \\
\text { size }\end{array}$ & $\begin{array}{c}\text { Number of } \\
\text { discontinuity } \\
\text { sets }\end{array}$ \\
\hline 1 & $\begin{array}{l}\text { Greenstone/ } \\
\text { metabasalt }\end{array}$ & $\begin{array}{l}\text { Dark greenish } \\
\text { gray to grayish } \\
\text { green }\end{array}$ & $\begin{array}{l}\text { Very } \\
\text { fine }\end{array}$ & R5 & Fresh & Blocky & $\begin{array}{l}\text { Very } \\
\text { small }\end{array}$ & $3-4$ \\
\hline 2 & Metabasalt & $\begin{array}{l}\text { Dark greenish } \\
\text { gray }\end{array}$ & $\begin{array}{l}\text { Fine to } \\
\text { very } \\
\text { fine }\end{array}$ & R5 & Fresh & Blocky & Medium & $>5$ \\
\hline 3 & Diorite & $\begin{array}{l}\text { Reddish black to } \\
\text { green }\end{array}$ & Fine & R5 & Slight & Blocky & Medium & 5 \\
\hline $4 a$ & Diorite & Dark reddish gray & Fine & R4 & Moderate & Blocky & Small & 5 \\
\hline $4 b$ & $\begin{array}{l}\text { Graywacke } \\
\text { metasandstone }\end{array}$ & Light bluish gray & $\begin{array}{l}\text { Very } \\
\text { fine }\end{array}$ & R5 & Slight & $\begin{array}{l}\text { Blocky to } \\
\text { shattered }\end{array}$ & Small & 4 \\
\hline $\begin{array}{c}5 \\
\text { (a and } b)\end{array}$ & $\begin{array}{l}\text { Graywacke } \\
\text { metasandstone }\end{array}$ & $\begin{array}{l}\text { Dark greenish } \\
\text { gray to light green }\end{array}$ & $\begin{array}{l}\text { Fine to } \\
\text { very } \\
\text { fine }\end{array}$ & R4-R5 & $\begin{array}{l}\text { Fresh to } \\
\text { slight }\end{array}$ & $\begin{array}{l}\text { Blocky, } \\
\text { columnar, } \\
\text { shattered }\end{array}$ & Medium & 3 \\
\hline 6 & Gabbro & $\begin{array}{l}\text { Light brownish } \\
\text { gray }\end{array}$ & Fine & R5 & $\begin{array}{l}\text { Fresh to } \\
\text { slight }\end{array}$ & Blocky & Medium & $>4$ \\
\hline 7 & $\begin{array}{l}\text { Diorite to } \\
\text { gabbro }\end{array}$ & $\begin{array}{l}\text { Dark greenish } \\
\text { gray }\end{array}$ & Fine & R5 & Slight & Blocky & Medium & 5 \\
\hline 8 & Chert & $\begin{array}{l}\text { Brownish red to } \\
\text { greenish blue }\end{array}$ & $\begin{array}{l}\text { Very } \\
\text { fine }\end{array}$ & R4 & Slight & Shattered & $\begin{array}{l}\text { Very } \\
\text { small }\end{array}$ & 3 \\
\hline 9 & Metabasalt & $\begin{array}{l}\text { Dark reddish to } \\
\text { yellowish gray }\end{array}$ & $\begin{array}{l}\text { Very } \\
\text { fine }\end{array}$ & R4 & Slight & Blocky & Medium & 2 \\
\hline 10 & $\begin{array}{l}\text { Basalt/ } \\
\text { greenstone }\end{array}$ & $\begin{array}{l}\text { Dark greenish } \\
\text { gray }\end{array}$ & $\begin{array}{l}\text { Very } \\
\text { fine }\end{array}$ & R5 & Slight & Blocky & Medium & 4 \\
\hline $\begin{array}{c}\text { Area } \\
\text { between } \\
10 \text { and } 11\end{array}$ & $\begin{array}{l}\text { Graywacke } \\
\text { metasandstone }\end{array}$ & $\begin{array}{l}\text { Greenish gray to } \\
\text { olive green }\end{array}$ & Fine & $\mathrm{R} 1-\mathrm{R} 4$ & Slight & Shattered & $\begin{array}{l}\text { Very } \\
\text { small }\end{array}$ & 3 \\
\hline 11 & Gabbro & Dark grayish black & Fine & R5 & Moderate & Blocky & Medium & 3 \\
\hline 12 & Diorite & Dark bluish gray & Fine & R5 & Slight & Blocky & Small & 3 \\
\hline 13 & $\begin{array}{l}\text { Metabasalt/ } \\
\text { greenstone }\end{array}$ & $\begin{array}{l}\text { Dark greenish } \\
\text { black }\end{array}$ & Fine & R5 & Slight & Blocky & Small & 4 \\
\hline
\end{tabular}

\section{Discontinuity data evaluation}

Jointing is pervasive throughout the rock mass for all bedrock types and, together with local faults and shear zones, divides the rock into discrete blocks and slabs. Joint dips are predominantly high angle (Appendix B) and may have formed during uplift or unroofing of the Yukon-Tanana Upland. Joint spacing is typically close to moderate in all rock types except chert, which exhibits extremely close to very close spacing possibly related to bedding-parallel shearing, or due to the very fine grain size. Joint surfaces are typically tight and smooth to slightly rough and planar with scattered slickensided shear surfaces. Scattered black oxidation staining and thin fillings of calcite and quartz are present on joint surfaces, however the majority of joints are clean. Aperture widths are commonly tight to very tight, with scattered joints partly open to open and rare very wide openings. Evidence of water flow was not observed on any discontinuity surface.

A wide area of sheared chloritic graywacke metasandstone with zones of more intense shearing and alteration is present between approximately 300 and 475 feet east of the Yukon River bridge (fig. 4). The graywacke between shear zones is strong rock (R4). The shear zones are characterized by very weak (R1), shattered and brecciated rock in a grayish green clay matrix with calcite veins. Shear zones are variably oriented with clusters striking $60^{\circ}-90^{\circ}$ 
azimuth and $145^{\circ}-170^{\circ}$ azimuth with vertical dips. The zones are $>18$ inches wide, closely spaced, and irregularly curved with calcite present as skins on shattered clasts. Individual shear planes in the zones are tight to open and have orientations similar to the major shear zones.

The 13 bedrock field stations are characterized by an array of joint and fault orientations. Rose diagrams and equal-area stereonet projections of the discontinuity data were plotted using the program Stereonet 8 (Allmendinger and others, 2012). Figures 5 and 6 show rose diagrams of joint orientations for each rock type and field station, respectively. The measurements were reflected across the rose diagrams for visual ease, so that both directions of each plane are visually represented. The bin size is 10 degrees, and the discontinuities are not weighted by length, persistence, spacing, or other factors.

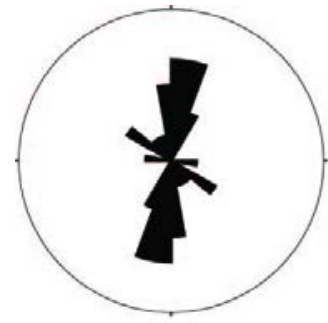

Chert

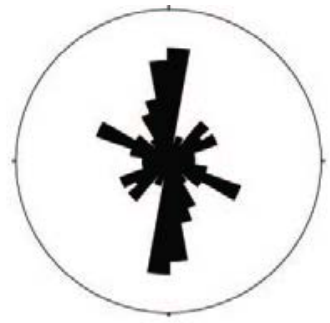

Diorite

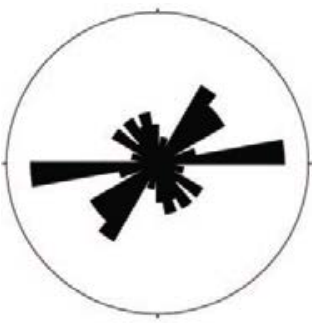

Gabbro

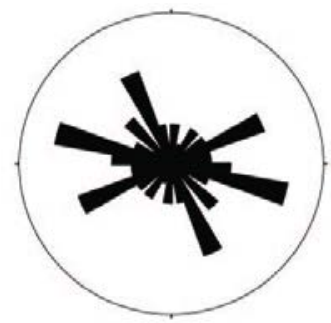

Graywacke

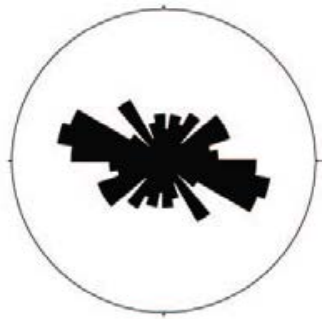

Greenstone

Figure 5. Rose diagrams of rock discontinuity data by rock type. Measurements are reflected across the rose diagrams so that both directions of each plane are represented.

Discontinuity orientations for the different rock types (fig. 5) show clear distinctions. Chert and dioritic rocks have similar fracture patterns with dominant N-S joint sets, and subdominant WNW-ESE and NE-SW fracture sets. These rock types are both fine grained, and the fractures may have broken the rock without being influenced by crystal size or pre-existing weaknesses. Fracture patterns in the gabbroic rocks are characterized by NE-SW and E-W fracture sets. Graywacke metasandstones are characterized by three dominant sets, NW-SE, NE-SW, and WNW-ENE. Pre-existing weaknesses related to bedding in the graywacke metasandstones may have been exploited by the fractures. Greenstones (metabasalts) have fracture patterns that are similar to the dominant WNW-ESE set in the graywacke metasandstones, but also contain NW-SE and NE-SW fracture sets. Shear zones and faults in the greenstones may have influenced the discontinuity orientations. The maxima of the dis-

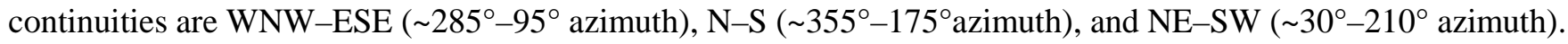

Additional patterns are evident in the rose diagrams for individual field stations (fig. 6), however because each station has only about 20 measurements, the patterns may reflect uneven sampling. The rose diagram for the combined dataset of all stations includes 610 discontinuity measurements (fig. 6). This plot generally shows the same major discontinuity sets as seen in the different bedrock type plots but is more scattered, illustrating the diverse complex fracture pattern that characterizes the site.

The strike and dip of the discontinuity surfaces and poles to discontinuity planes were also plotted on equalarea stereonet projections (fig. 7). For the entire data set, no distinct patterns are evident in the composite stereonet projections of the strike and dip measurements (fig. 7A). As with the rose diagrams, grouping stereonets by station and rock type may reveal more robust patterns, however, this is beyond the scope of our study. The plot of the poles to the discontinuity planes shows several distinct clusters in the main populations (fig. 7B). The lines around the clusters are 1 percent area contours. The main plane orientations dip nearly vertical (scattered toward the edges of the net) and are similar to the rose diagrams; the dominant WNW-ENE planes are the cluster of poles plotting slightly $\mathrm{E}$ of $\mathrm{N}$, and the dominant $\mathrm{N}-\mathrm{S}$ planes are the cluster of poles near the $\mathrm{E}$ and $\mathrm{W}$ edges of the net. The NE-SW planes do not show up as a large cluster of poles, but there are small clusters dipping less vertically $\left(\sim 75^{\circ}\right)$ in the NW and SE quadrants. The last cluster of poles, approximately $45^{\circ} \mathrm{E}$ of $\mathrm{N}$ near the plot edge, is the near-vertical NW-SE set of discontinuity planes. 


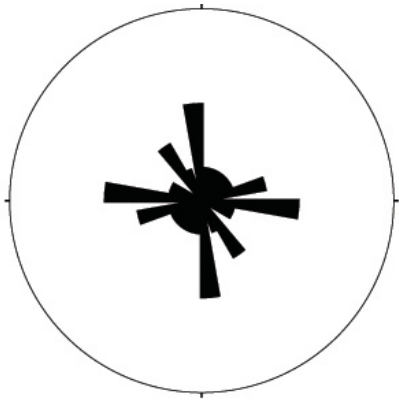

Station 1

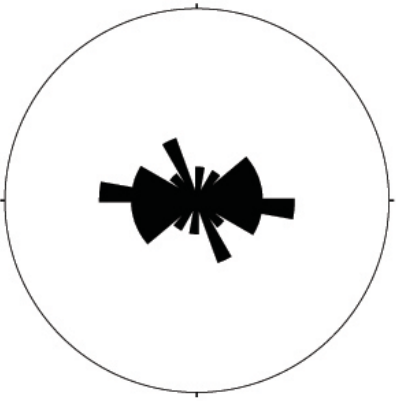

Station $4 b$

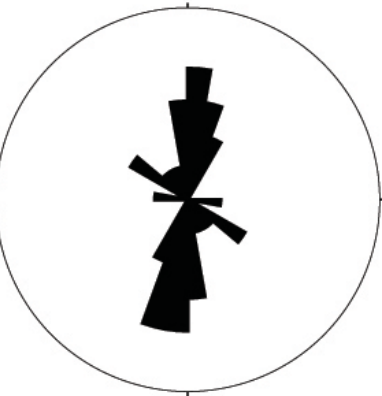

Station 8

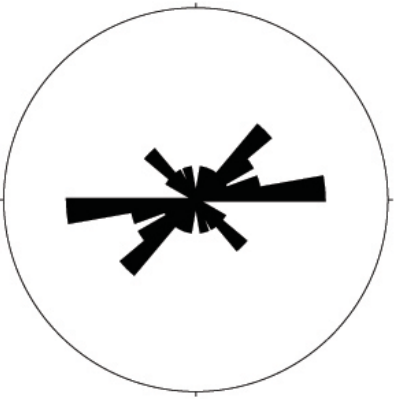

Station 12

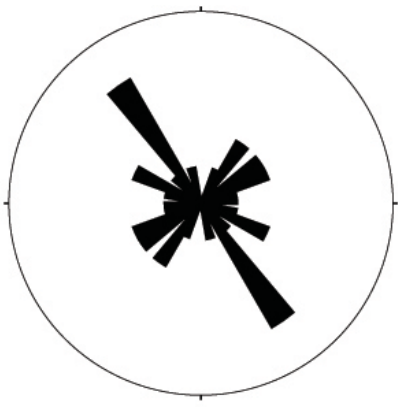

Station 2

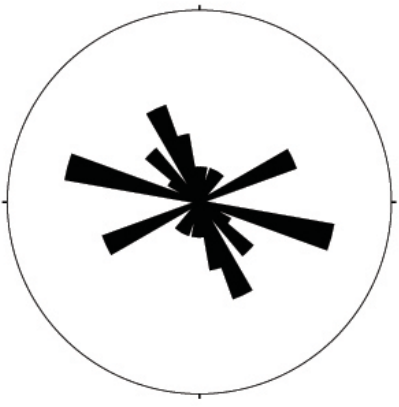

Stations $5 a$ and $5 b$

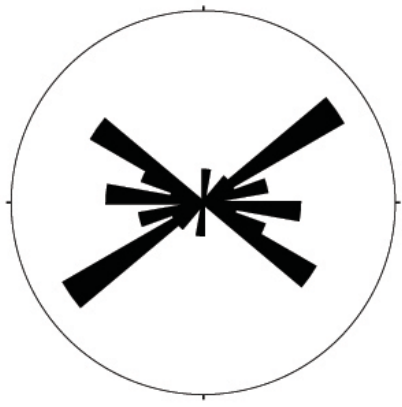

Station 9

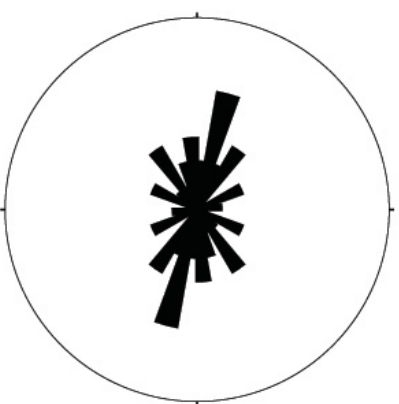

Station 13

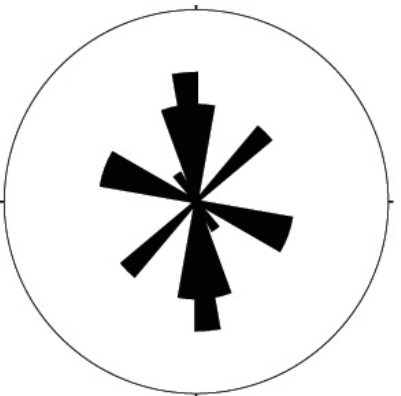

Station 3

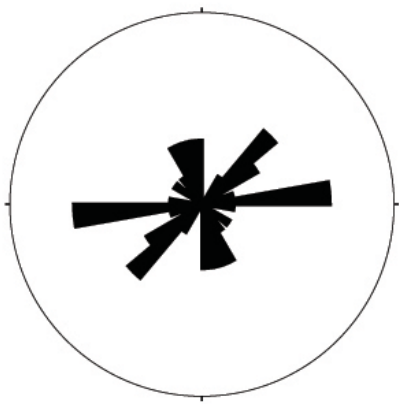

Station 6

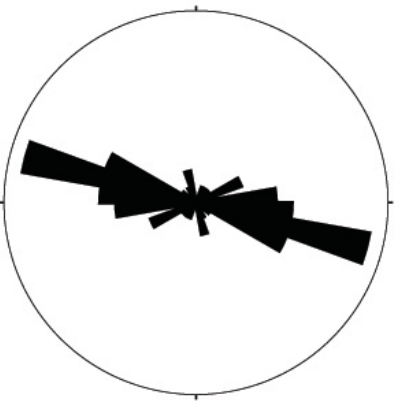

Station 10

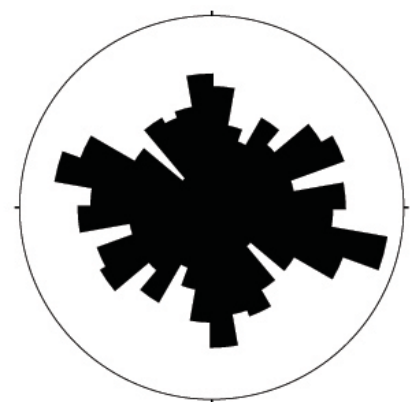

All stations combined

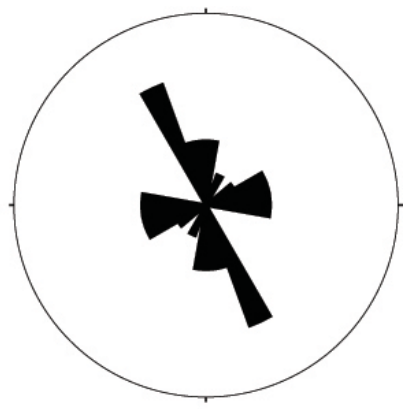

Station $4 a$

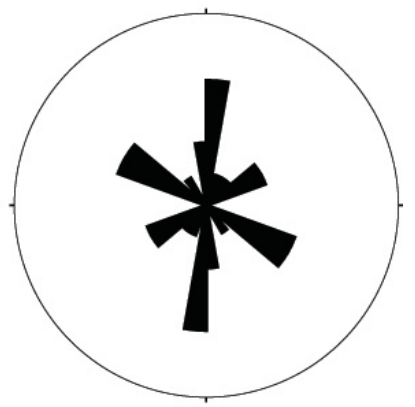

Station 7

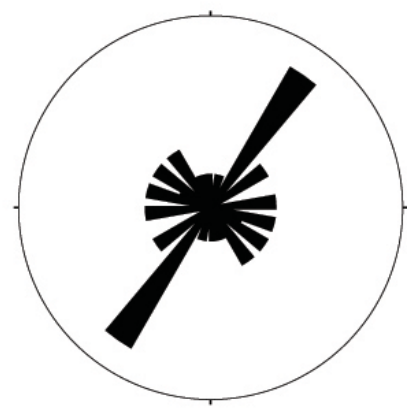

Station 11

Figure 6. Rose diagrams of rock discontinuity data from each measurement station, and composite plot of the combined dataset (lower right). Measurements are reflected across the rose diagrams so that both directions of each plane are represented. 

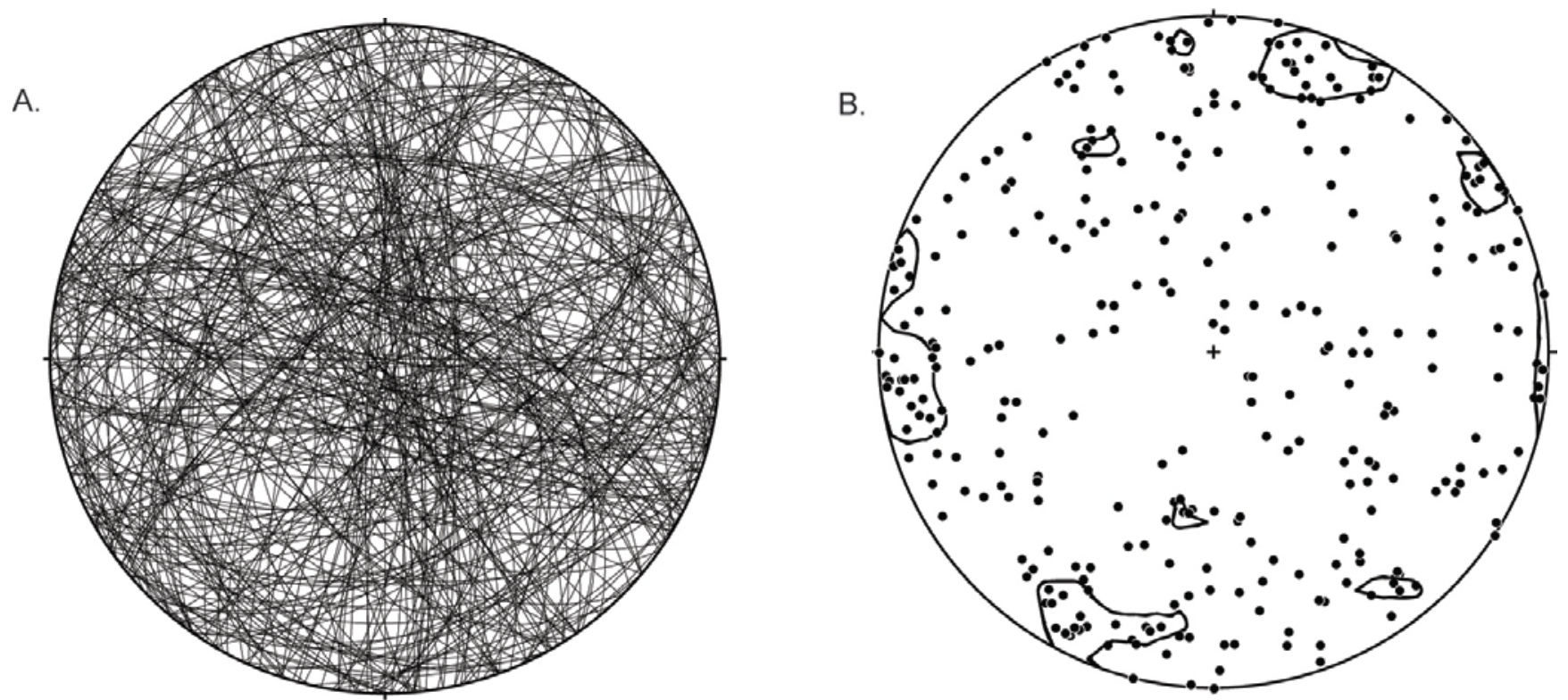

Figure 7. Stereonet projections of rock discontinuity data. A. Equal area stereonet projections for all discontinuity data.

B. Poles to the discontinuity planes for all discontinuity data. Lines around clusters are 1 percent area contours.

There are additional ways to analyze the discontinuity data, but these studies should be driven by the goals of future slope stability evaluations and are beyond the scope of this evaluation. For example, discontinuities could be weighted based on important factors such as their length, persistence, spacing, oxide staining, fillings, and other characteristics. The discontinuities could be evaluated spatially, which could reveal patterns related to proximity to shear zones or large faults. Different blocks may exist in areas with different stresses acting on them currently or in the past. Additionally, the fractures proximal to the landslide could be compared to more distal fractures to evaluate whether there are more-dominant fracture sets that could have controlled the bedrock failure in the area of the landslide. A preliminary test of this hypothesis did not yield patterns.

\section{Fault evaluation}

Evaluation of fault orientations can provide insight into the state of stress at the time of faulting. Large datasets are needed to determine the current and past stress fields, since stress usually changes through time, and records of these different states of stress are recorded in the rocks. Cross-cutting relations and mineral growth on fault surfaces are extremely useful for evaluating these stresses. Also, conjugate fault sets are much more instructive than independent fault planes in evaluating and determining the state of stress. The pattern of slip on a simple conjugate array of mesoscopic faults is directly related to the state of stress at the time of faulting.

We measured 37 mesoscopic faults in the area around the Yukon River bridge, 33 of which had shear fractures with slicken surfaces. The lack of openings, water flow, gouge, and damage zones on the majority of these faults indicates that they are likely old, and no evidence of recent movement was observed. Some of the shear surfaces showed two different sets of slickenlines with different sets of motion, indicating that the movement had changed. The slip planes of some of these features appeared to be along curviplanar quartz and sometimes epidote veins (plus or minus chlorite), and were sealed or very tight. This suggests that the tensile openings were exploited as slip surfaces. Conversely, the veins could have taken advantage of the fault openings and slickenlines may have been created by continued slip. Either way, the sealed nature of the fractures suggests that this tensile state has passed. Further fault analyses could elucidate the sequence of past structural deformation in the area, however it would not help determine the current state of stress. Thus we did not analyze the faults separately. 


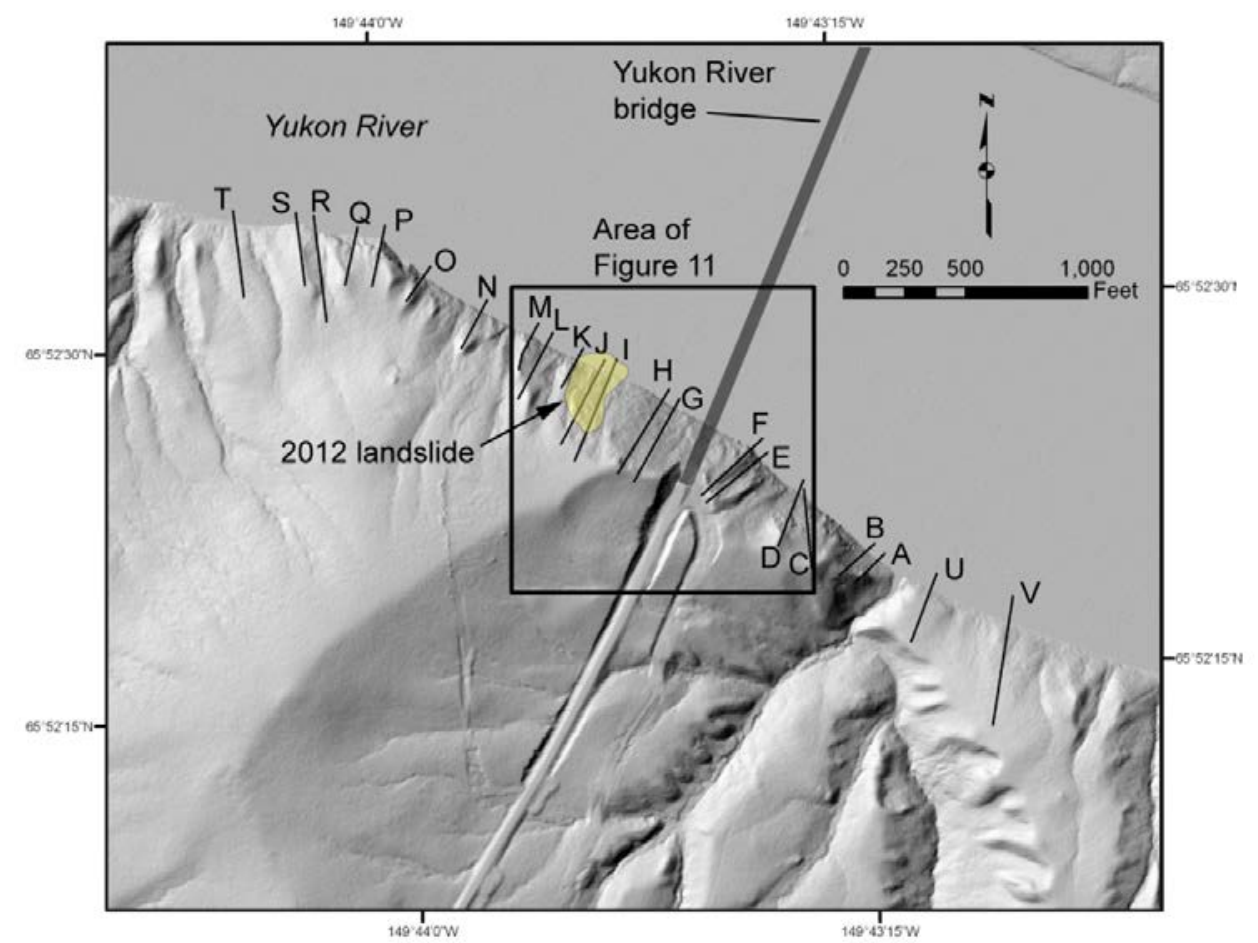

Figure 8. Site vicinity map, showing locations of topographic profiles (thin black lines labeled with letters) and Yukon River landslide (yellow polygon). Black box shows location of detailed views of the site in figure 11.

Figure 9. Topographic profiles A-H and K-V across the southern bluff of the Yukon River in the vicinity of the Yukon River bridge. Figure 8 shows the location of each profile. Profiles I and J across the Yukon River bridge landslide are shown in figure 12.
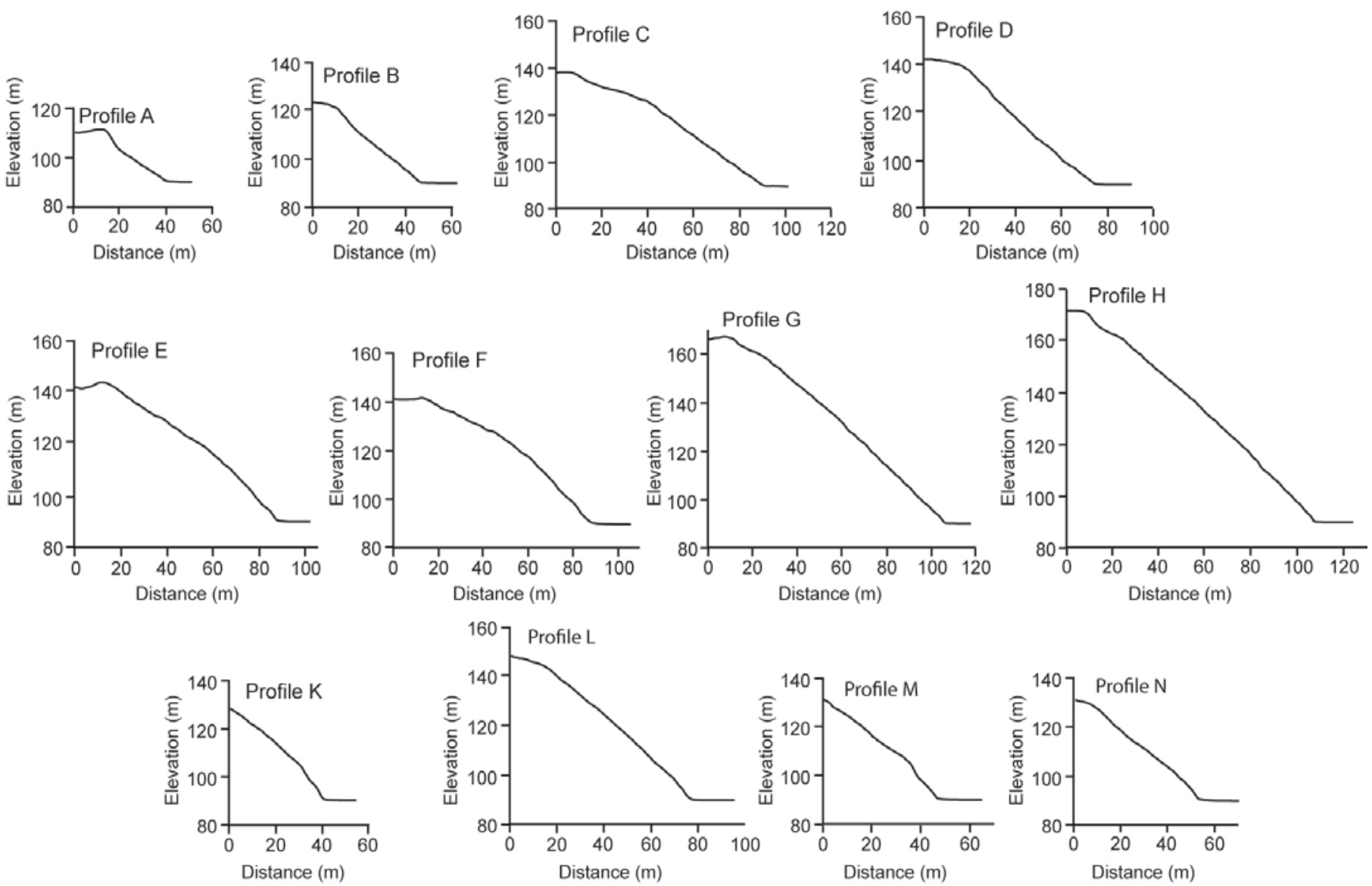
Figure 9, continued
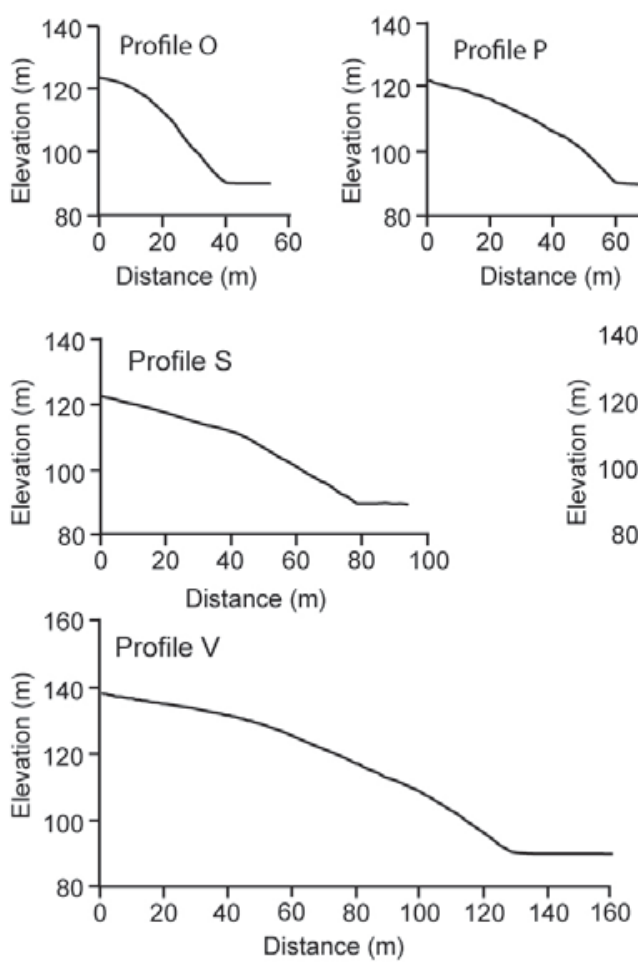
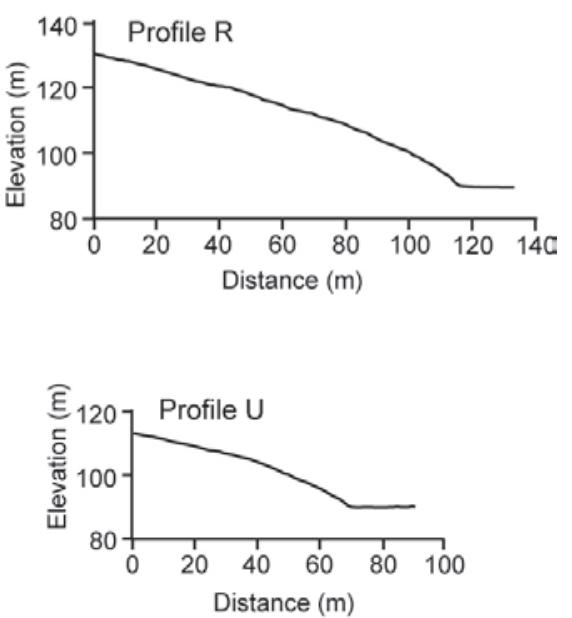
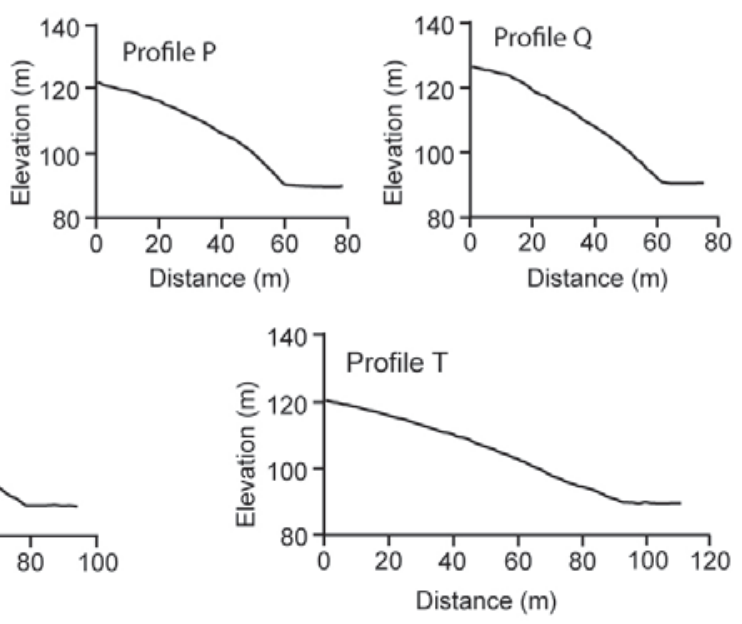

Figure 10. Geo-

morphic interpretation of the Yukon River bridge area, showing the 2012 landslide and zones of prior slope instability.

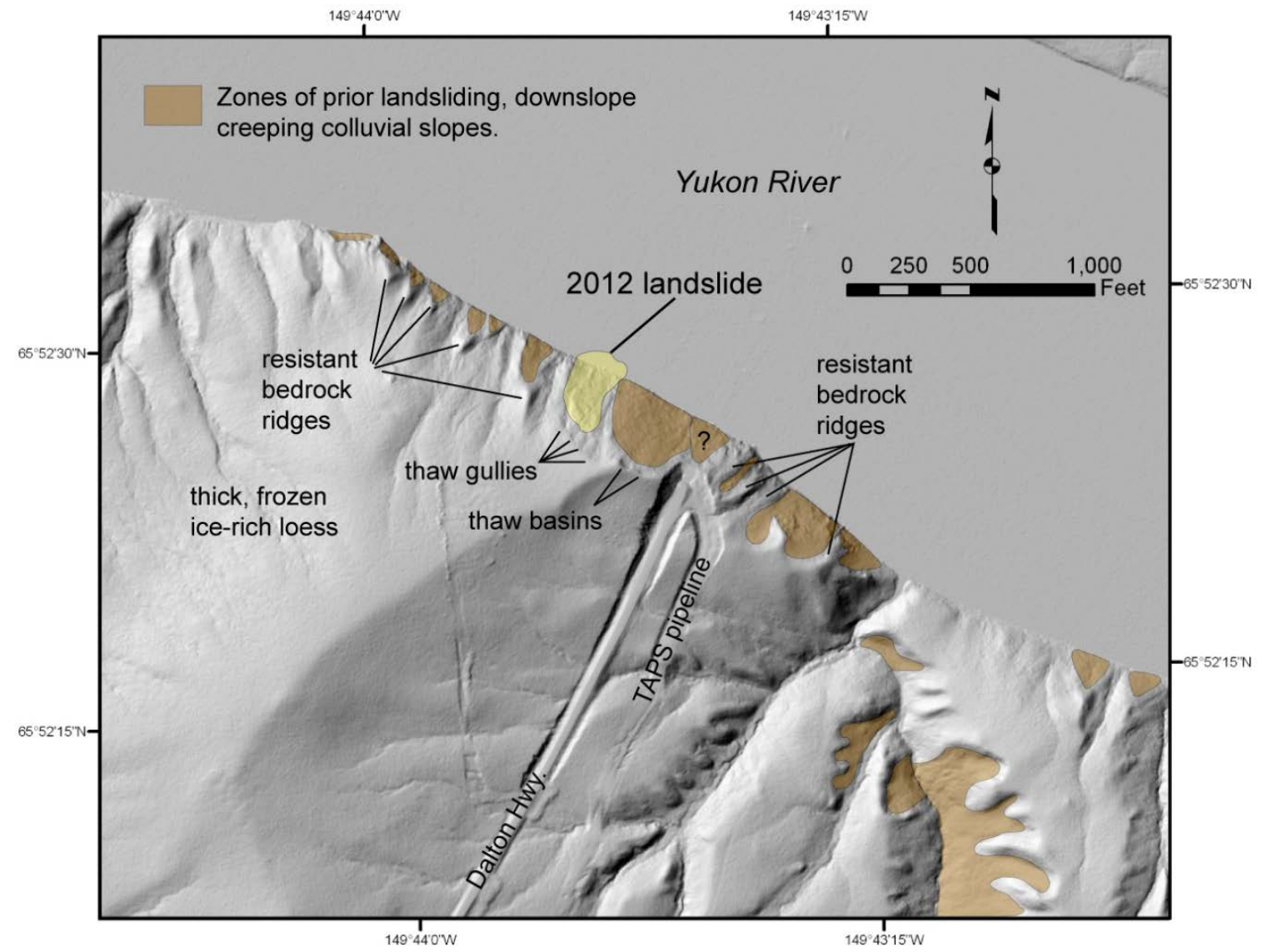


Results of slope and landslide geomorphology evaluation

General slope conditions and the location of individual slope profiles are shown in figure 8; profiles are in figure 9. A LiDAR interpretation of the location of prior landsliding and/or other downslope colluvial transport processes is shown on figure 10. For the areas upstream and downstream of the bridge, LiDAR imagery of the bluff shows several vegetated possible landslide slopes separated by steep, narrow bedrock ridges that are relatively stable (fig. 10). Surfaces above the crest of the bluff slopes are mantled by thick, frozen ice-rich loess and characterized by gentle slopes and common thaw gullies and basins. Geomorphic features indicative of active faulting are absent on the surface. In particular, there is no indication of recent along-strike activity of the fault identified in the foundation of bridge pier 4 . In the field, helicopter surveys and boat reconnaissance were conducted along the bluff to look for evidence of prior landsliding for approximately 2,000 feet upstream and downstream of the bridge; however, no scarps or obvious debris hollows were observed.

Table 3. Characteristics of LiDAR-derived slope profiles evaluated for evidence of slope instability.

\begin{tabular}{|c|c|c|}
\hline $\begin{array}{c}\text { Profile } \\
\text { designation }\end{array}$ & Evaluation scale & Comments \\
\hline A & 1:398 & Slope planar @ 35.5․ Slow creep/gelifluction likely. \\
\hline B & $1: 521$ & Slope planar @ 38.5․ Slow creep/gelifluction likely. \\
\hline $\mathrm{C}$ & 1:565 & Slope planar @ 36.5․ Slow creep/gelifluction likely. \\
\hline $\mathrm{D}$ & $1: 610$ & Slope planar @ 38 . Slow creep/gelifluction likely. \\
\hline $\mathrm{E}$ & 1:530 & $\begin{array}{l}\text { Steep gully between bedrock ridges contains slope debris. Possible small failure below } 324 \mathrm{ft} \\
\text { elevation due to river undercutting. }\end{array}$ \\
\hline $\mathrm{F}$ & $1: 549$ & $\begin{array}{l}\text { Steep nose of bedrock ridge. Lower section appears oversteepened by river erosion. } \\
\text { Possible slope failure below } \sim 40 \mathrm{ft} \text { elevation. }\end{array}$ \\
\hline G & 1:719 & Possible slope failure below $\sim 539 \mathrm{ft}$ elevation. \\
\hline $\mathrm{H}$ & $1: 698$ & Possible slope failure below $543 \mathrm{ft}$ elevation. \\
\hline I & $1: 693$ & 2012 landslide below $\sim 507 \mathrm{ft}$ elevation. \\
\hline $\mathrm{J}$ & $1: 273$ & 2012 landslide below $\sim 477 \mathrm{ft}$ elevation. \\
\hline $\mathrm{K}$ & $1: 278$ & $\begin{array}{l}\text { Steep nose of bedrock ridge. Possible slope failure at } \sim 325 \mathrm{ft} \text { elevation due to undercutting } \\
\text { by river. }\end{array}$ \\
\hline $\mathrm{L}$ & $1: 522$ & $\begin{array}{l}\text { Uniform slope of } 40^{\circ} \text {. Possible slope failure below } \sim 332 \mathrm{ft} \text { elevation due to undercutting by } \\
\text { river. }\end{array}$ \\
\hline M & $1: 347$ & Steep $\left(40^{\circ}\right)$ nose of bedrock ridge. Possible slope failures below 339 and 317 ft elevation. \\
\hline $\mathrm{N}$ & $1: 348$ & Steep $\left(40^{\circ}\right)$ nose of bedrock ridge. Steepened to $43^{\circ}$ below $\sim 325 \mathrm{ft}$ elevation. \\
\hline $\mathrm{O}$ & $1: 348$ & Steep $\left(45.5^{\circ}\right)$ nose of bedrock ridge. Top of possible landslide at $\sim 334 \mathrm{ft}$ elevation. \\
\hline $\mathrm{P}$ & $1: 523$ & $\begin{array}{l}\text { Margin of possible dissected, old landslide below } 372 \mathrm{ft} \text { elevation in hollow west of } \\
\text { prominent bedrock point. }\end{array}$ \\
\hline Q & $1: 521$ & $\begin{array}{l}\text { Axis of possible dissected, old landslide with top at } \sim 385 \mathrm{ft} \text { elevation and surface slope of } \\
28^{\circ} \text {. Slope steepens to } 44^{\circ} \text { below } \sim 338 \mathrm{ft} \text { elevation due to river erosion. Top of possible } \\
\text { younger landslide at } \sim 321 \mathrm{ft} \text { elevation. }\end{array}$ \\
\hline $\mathrm{R}$ & $1: 521$ & $\begin{array}{l}\text { Gully fill between bedrock ridges slopes } 17^{\circ} \text {. Slope steepens to } 31.5^{\circ} \text { at } \sim 337 \mathrm{ft} \text { elevation in } \\
\text { response to river erosion. }\end{array}$ \\
\hline $\mathrm{S}$ & $1: 521$ & Loess-covered bedrock ridge. Nose slopes consistent $28^{\circ}$ below $\sim 361 \mathrm{ft}$ elevation. \\
\hline $\mathrm{T}$ & $1: 539$ & Loess-covered bedrock ridge slopes consistently at $20^{\circ}$ below $\sim 358 \mathrm{ft}$ elevation. \\
\hline$U$ & --- & Not evaluated. \\
\hline V & --- & Not evaluated. \\
\hline
\end{tabular}

Profiles derived from LiDAR data demonstrate that vegetated possible landslide surfaces slope between $35^{\circ}$ and $42^{\circ}$ and the steep, lower crests of resistant bedrock ridges slope approximately $40^{\circ}$ to $68^{\circ}$. Table 3 shows the scale at which slopes were evaluated and the slope interpretation for each profile. Between rock exposures on unfailed slopes, 2-3 feet of loess overlie 4-6 feet of pebbly, silty colluvium derived from downslope transport of loess and weathered bedrock. Slopes adjacent to the 2012 landslide display surface evidence of downslope movement, 
including numerous bent trees and shrubs, solifluction lobes, and scattered 10- to 20-foot-long, gaping transverse cracks. Profiles A through H and K through Q show oversteepened bases that may be a result of river erosion or past massive floods and/or ice scour (fig. 9). These profiles are located in the zone of possible previous slope movements shown on figure 10. Although some of these slopes may have catastrophically failed in mass wasting events, they may also reflect long-term downslope creep and gelifluction of weathered (residual) bedrock and loess. The absence of large colluvial hollows and debris blocks, as well as the relatively planar morphology of the slope suggests that the latter is the more dominant process of slope modification. Profiles R through V show more subdued profiles and are generally west and east of the zone of possible slope movements. In these areas, the slopes are not faceted and appear relatively stable.

A.

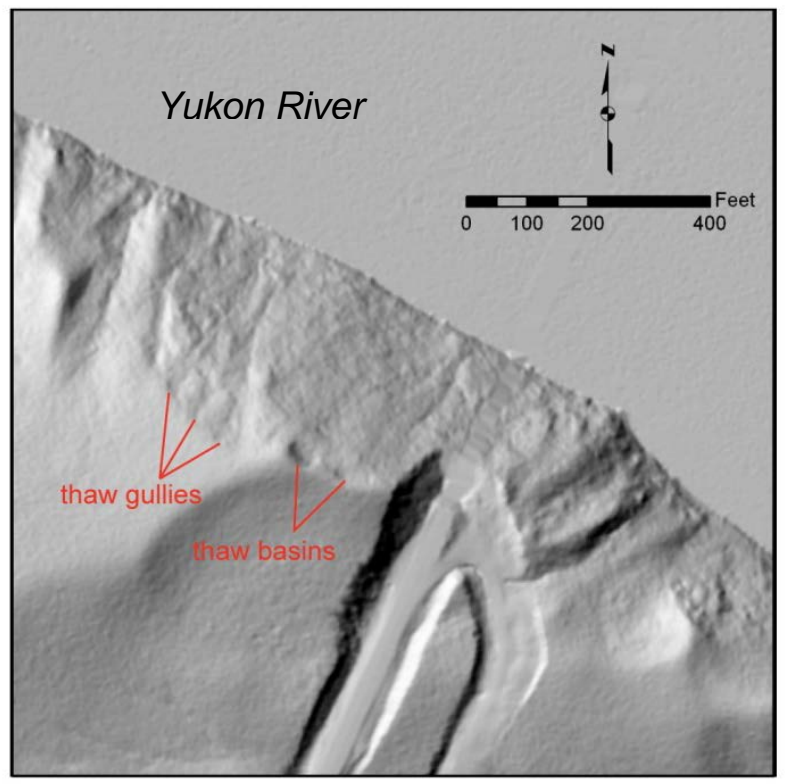

B.

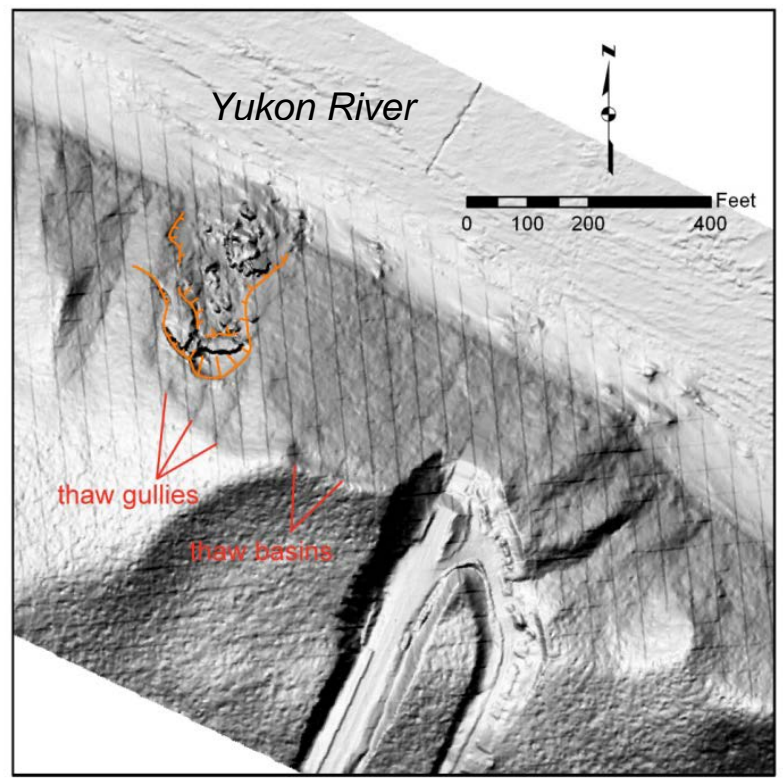

Figure 11. Pre- and post-landslide hillshade images derived from 2010 and 2013 LiDAR data. A. Pre-landslide hillshade.

B. Post-landslide hillshade; edges of landslide scarps shown by orange lines.

A comparison of the pre- and post-landslide surface and profiles across the landslide are shown in figures 11 and 12, respectively. Photographs of key features on the landslide are shown in Figure 13. In the pre-landslide hillshade image, hummocky topography along the slope indicates the possible presence of previous slope instability. Thaw gullies at the crest of the slope may have contributed to previous slope movements. The 2012 landslide occurred along the downstream end of the thaw gullies. Based on the distribution of headscarps (orange lines on fig. 11B), the 2012 landslide initiated on the east and propagated to the west. Blocks of debris in the mid-slope region and a large debris cone at the base of the slope are clearly visible on the LiDAR. Based on the LiDAR data, the main slide mass, including the area of the debris cone, is approximately 90-100 feet wide and approximately 220 feet long, however the bulk of the debris was sourced from an approximately $90 \times 100$-foot translational slide block in frozen loess at the top of the slope (fig. 13B). In addition to the frozen loess, a large slab of highly weathered gabbro also failed. Also present are two additional blocks of rock and colluvium that did not catastrophically fail down the slope. An approximately50x50-foot block on the western side of the headscarp separated from the slope across a large fracture. This block is underlain by fairly competent, fractured graywacke metasandstone and was likely made unstable after the main slide eroded the downslope side of the block, removing lateral support and causing slip to occur along fracture planes. Midway along the western margin of the slide a second block, measuring approximately $50 \times 100$ feet, separated approximately three feet from the adjacent inplace slope (fig. 13D). This block may be susceptible to future sliding. 

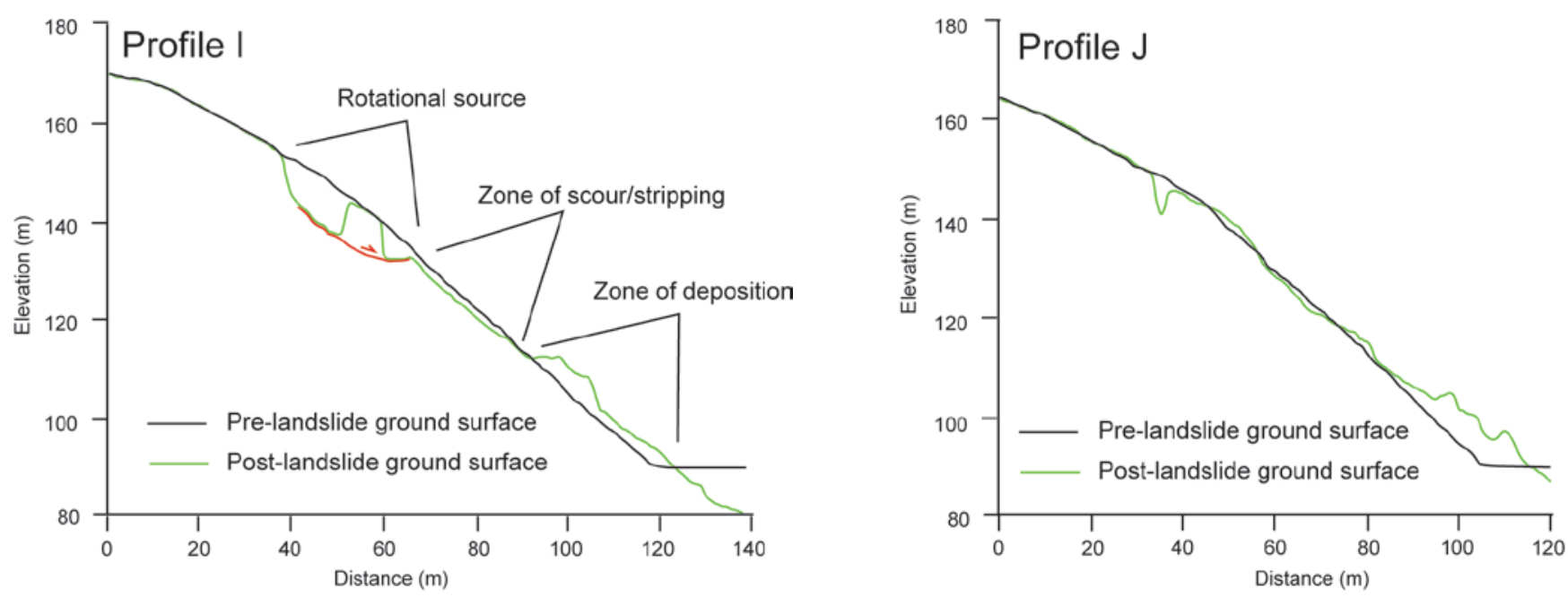

Figure 12. Topographic profiles I and J across the Yukon River bridge landslide showing the pre- and post-landslide ground surface. Pre-landslide ground surface derived from LiDAR data collected by DGGS (Hubbard and others, 2011). Postlandslide ground surface derived from LiDAR data collected by Alyeska Pipeline Service Company in April 2013. Inferred slide plane indicated in orange on Profile I.

Topographic profiles I and J were generated from the pre- and post-landslide LiDAR data across the eastern and western sides of the body of the 2012 landslide. They demonstrate that the crown of the slide is approximately 236 feet above low-water level (fig. 12). The profiles show that the landslide occurred on a slope of approximately $40^{\circ}$ and that the post-landslide slope is around $35-37^{\circ}$, which was confirmed by direct measurements in the field. Profile I, down the main body of the landslide, shows three distinct zones including an upper block failure, a mid-slope zone of scour and stripping, and a lower zone of slide debris deposition (fig. 12A). Flood deposits on the lower part of the debris cone indicate that break-up floods in spring 2013 did not remove an appreciable amount of slide debris. Profile J, measured on the slope directly west of the main slide body, shows a large tension fracture and only subtle translation of the slope mass (fig. 12B).

Three 20- to 30-foot-wide former thaw gullies are present on the slope across the top of the landslide, but their rounded cross profiles indicate that they are filled with loess and retransported loess and are no longer active. Along the upper marginal scarps and headwall of the failure, the loess displays closely-spaced planar structures that generally parallel the ground surface. In Interior Alaska, such planes develop in loess during the annual freezing of the ground by the formation of very thin, clear, parallel to subparallel, segregated ice lenses (French, 2007). Parallel shear planes also develop parallel to the slope during slow downslope creep of the loess, and downslope creep likely produced the parallel shear planes in the underlying frozen colluvium. A 5-inch-wide wedge of clear ice was visible for approximately 5 feet across the freshly exposed headwall of the landslide, demonstrating that the permafrost table was approximately 2 feet deep at the end of August 2013. The ice wedge formed when precipitation or meltwater entered and froze in an open transverse crack on the perennially frozen slope. No other visible ice was observed in the permafrost there, and no evidence of meltwater from thawing permafrost was observed in or around the landslide.

Field observations indicate that the large landslide blocks of frozen loess, colluvium, and highly weathered bedrock were not rotated during downslope motion but slid on the underlying, more competent bedrock on a shallow, planar, translational slide plane. Northwest-trending transverse open cracks and their ice fillings likely had a significant impact on the locations and sizes of the block failures. Additionally, long-term creep and gelifluction on the slope may have contributed to progressively greater tension that eventually exceeded the tensile strength in the frozen blanket of loess and colluvium. Deeper slide planes may also have developed along 
intersecting fracture planes in the highly weathered gabbro, which is altered to seamy clay. After initial failure, the displaced blocks collapsed and cascaded down the steep slope as a debris slide, stripping 2-3 feet of colluvium off the underlying bedrock in the mid-slope region, and depositing a large debris cone over the lower 90 feet or so of the slope. The debris cone is characterized by angular chert, gabbro, and graywacke metasandstone fragments, averaging 4-18 inches in diameter. Several large debris blocks with trees in growth position were deposited on the slope (fig. 13C). The zone of stripping and talus deposition is shown in figure 13A. Although a more detailed site investigation is necessary to more accurately define the slide plane and mechanism of failure, the field observations are consistent with a block glide transitioning downslope to a debris slide (Varnes, 1958).

A.

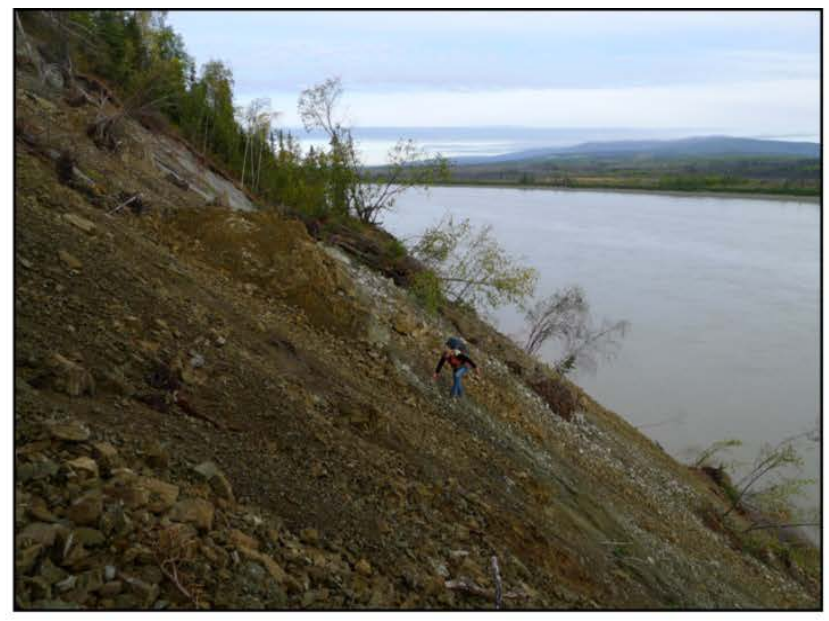

B.

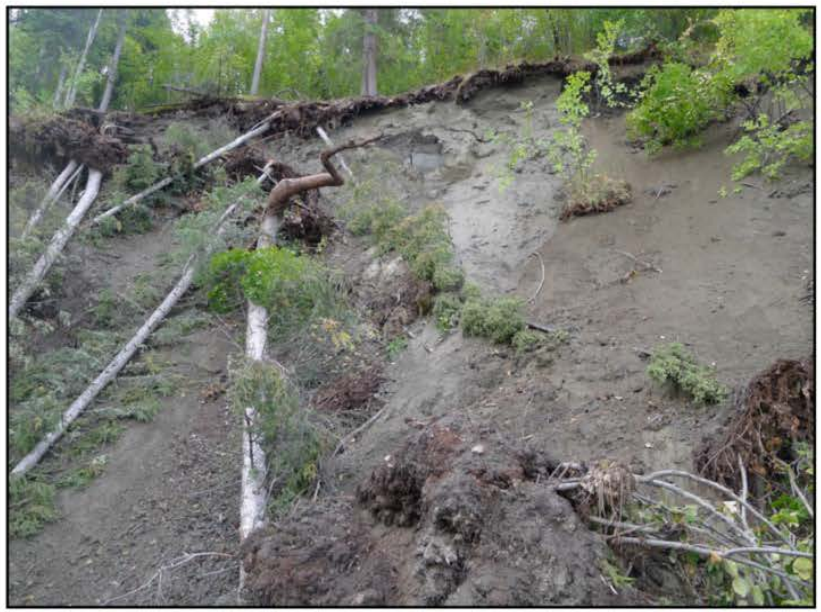

C.

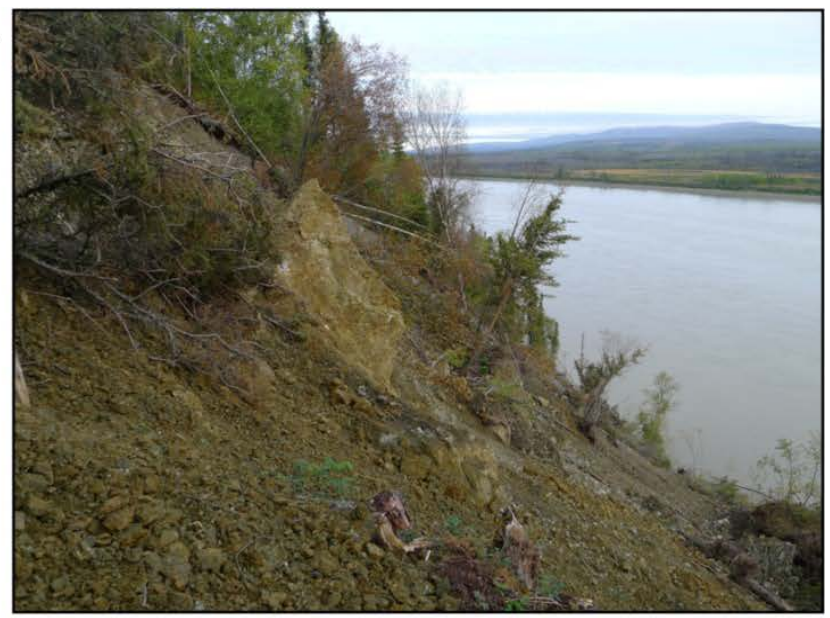

D.

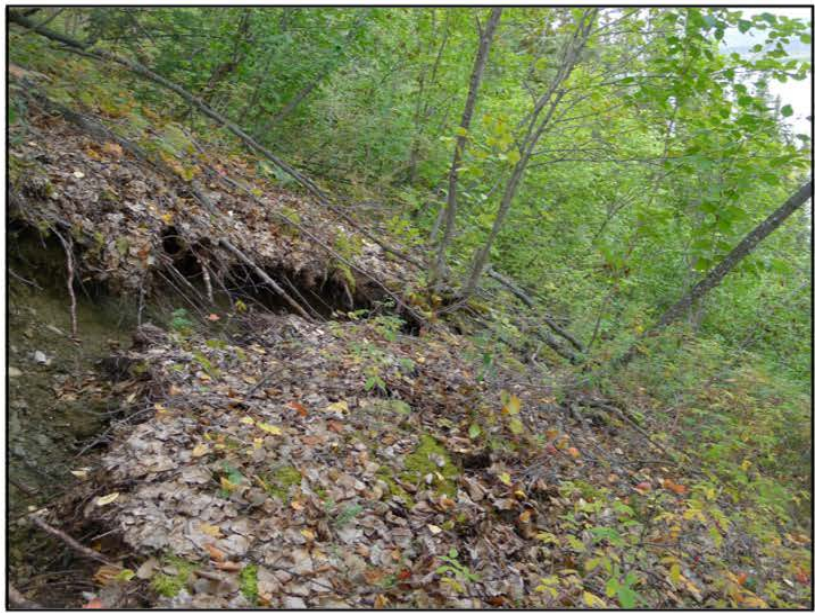

Figure 13. Photographs of the Yukon River landslide. A. Upper part of debris cone. Light gray color in upper left is exposed graywacke bedrock. B. Intact block of weathered gabbro bedrock on the surface. C. Frozen silt exposed in the headscarp. $D$. Separation scarp extending west of the middle part of the slide. 


\section{Conclusions and Recommendations}

The 2012 landslide occurred adjacent to the Yukon River bridge, but the bridge foundation did not sustain any damage. The slide initiated in frozen loess and retransported loess, but also involved the underlying highly weathered, weak bedrock (gabbro and graywacke metasandstone). The high density of fractures, joints, shear zones, and minor faults in the rock mass likely contributed to instability, and active faulting was not a factor. Tension in the overlying loess related to transverse cracks and ice fillings and the influence of surface hydrology may also have contributed to the slope failure. The relative roles of these potential causative factors are not completely understood. Based on the surface geomorphology, we conclude that the slide is most consistent with a block glide failure transitioning downslope to a debris slide.

The bedrock and discontinuity survey determined that the bedrock along the base of the bluff is primarily composed of metabasalt (greenstone), diorite, gabbro, graywacke metasandstone, and chert with minor limestone, all of which is fresh and strong. The rocks are closely jointed, with dominant joint sets oriented WNW-ESE, NESW, N-S, E-W, NW-SE. These joint patterns likely extend throughout the rock mass, which includes zones that are highly altered and intensely weathered upslope. Our assessment of slopes in the vicinity of the bridge indicates that slopes are $>40^{\circ}$ and are mantled by fairly thin colluvium. The crest of the slope is buried by thick frozen loess. The interaction of gelifluction and ice and soil processes with the intensely fractured rock provides favorable driving forces for slope failure.

Several arcuate, open fractures are present south of the main headscarp of the 2012 landslide, indicating that additional smaller landslide blocks are poised for future downslope displacements. The slightly separated slope along the western margin of the landslide is prone to future failure, assuming continued loss of lateral support and steepening of the base of the slope by Yukon River erosion. Thaw basins at the top of the slope between the landslide and the Yukon River bridge, as well as the presence of gelifluction and active creep features, indicate the possibility of similar slope failures occurring in that area in the future. Although the potential exists for future slope failures, the lack of any significant landslide scars along the bluff upstream and downstream of the bridge indicates that large-scale failures are a rare occurrence. The 2012 landslide is the first landslide of this type and scale at least since the construction of the Yukon River bridge in 1974-75 and probably for at least 20 years previously.

Our geologic and geomorphic evaluation has determined that the fractured bedrock and steep slopes in the bridge vicinity are prone to slope failure. Given the significant landslide hazard adjacent to the Yukon River bridge and Trans-Alaska Pipeline System, and the potential impact of damage to the bridge to the state's economy, it is recommended that a monitoring and instrumentation program be initiated on the slope adjacent to the bridge to better understand the landslide risk. The instrumentation program should include the installation of piezometers, extensometers, and tiltmeters. Detailed hydrologic studies aimed at characterizing drainage patterns, and a geotechnical study focused on characterizing subsurface conditions and an estimate of "Factor of Safety" are also recommended, particularly in the critical area between the 2012 landslide and the Yukon River bridge.

\section{Closure and Limitations}

This report was prepared to convey to the public the general characteristics of the rock mass, characteristics of rock discontinuities, and the geomorphic expression of the 2012 landslide in the vicinity of the Yukon River bridge. The observations and conclusions contained in this report are based on site conditions on the dates of the field evaluations discussed herein and are the opinions of the authors. The information contained in this report should be considered preliminary and should not be used to determine areas of potential future slope instabilities. A significant amount of additional exploration and slope stability analysis are required to fully understand the landslide hazard in the area of the bridge, as well as the potential for reactivation and/or expansion of the 2012 landslide into adjacent slopes. 


\section{Acknowledgments}

The authors appreciate the coordination among Steve McGroarty, Jeff Currey, Kevin Maxwell, and Garrett Speeter of (ADOT\&PF) and Frank Wuttig of Alyeska Pipeline Services Company at pre-project briefing and planning meetings as well as during our field evaluation. Alyeska graciously provided helicopter support for our initial reconnaissance. Robert Joseph of Stevens Village expertly guided our boat-based river surveys. Eric Hatleberg of DNR's State Pipeline Coordinator's Office provided valuable feedback regarding our work during a field review. We thank De Anne Stevens of DGGS for an insightful review of the report.

\section{References}

Alaska Department of Transportation \& Public Facilities, 2003, Alaska field rock classification and structural mapping guide: State of Alaska, ADOT\&PF Geotechnical Procedures Manual, 31 p.

Allmendinger, R.W., Cardozo, Nestor, and Fisher, D.M., 2012, Structural Geology Algorithms—Vectors and Tensors: New York, Cambridge University Press, 302 p., ISBN 978-1-10-740138-9.

Clement, D.T., 1999, Fluvial geomorphology of the Yukon River, Yukon Flats, Alaska: Calgary, University of Calgary MS thesis, $180 \mathrm{p}$.

Dover, J.H., 1994, Geology of part of east-central Alaska, in Plafker, George, and Berg, H.C., eds., The Geology of Alaska: Boulder, Colorado, Geological Society of America, The Geology of North America, v. G-1, p. 153-204.

French, H.M., 2007, The periglacial environment: Chichester, England, John Wiley \& Sons, Ltd., 458 p.

Froese, D.G., Smith, D.G., Westgate, J.A., Ager, T.A., Preece, S.J., Sandhu, A., Enkin, R.J., and Weber, F., 2003, Recurring middle Pleistocene outburst floods in east-central Alaska: Quaternary Research, v. 60, no. 1, p. 50-62.

Hubbard, T.D., Koehler, R.D., and Combellick, R.A., 2011, High-resolution LiDAR data for Alaska infrastructure corridors, in DGGS Staff, LiDAR Datasets of Alaska: Alaska Division of Geological \& Geophysical Surveys Raw Data File 20113, 291 p., http://www.dggs.alaska.gov/pubs/id/22722.

International Society for Rock Mechanics (ISRM), 1978, Suggested methods for the quantitative description of discontinuities in rock masses: International Society for Rock Mechanics, International Journal of Rock Mechanics and Mining Sciences and Geomechanics Abstracts, Vol. 15.

Jones, D.L., Silberling, N.J., Chapman, R.M., and Coney, P., 1984, New ages of radiolarian chert from the Rampart district, east-central Alaska: U.S. Geological Survey Circular 868, p. 39-43.

Kreig, R.A., and Reger, R.D., 1982, Air-photo analysis and summary of landform soil properties along the route of the TransAlaska Pipeline System: Alaska Division of Geological \& Geophysical Surveys Geologic Report 66, 149 p.

Mertie, J.B., 1937, The Yukon-Tanana region: Alaska, U.S. Geological Survey Bulletin 872, 276 p.

Shur, Yuri, Kanevskiy, Mikhail, Dillon, Matthew, Stephani, Eva, and O’Connell, Jonathan, 2010, Geotechnical investigations for the Dalton Highway Innovation Project as a case study of the ice-rich syngenetic permafrost: Alaska Department of Transportation \& Public Facilities Report FHWA-AK-RD10-06, 160 p.

Thorson, R.M., 1989, Late Quaternary paleofloods along the Porcupine River, Alaska-Implications for regional correlation, in Carter, L.D., Hamilton, T.D., and Galloway, J.P., eds., Late Cenozoic history of the interior basins of Alaska and the Yukon: U.S. Geological Survey Circular 1026, p. 51-54.

Thorson, R.M., and Dixon, J.E., Jr., 1983, Alluvial history of the Porcupine River, Alaska-Role of glacial-lake overflow from northwest Canada: Geological Society of America Bulletin, v. 94, no. 5, p. 576-589.

Varnes, D.J., 1958, Landslide types and processes: Washington, DC, Highway Research Board, Special Report 29, p. $20-47$.

Wahrhaftig, Clyde, 1965, Physiographic divisions of Alaska: U.S. Geological Survey Professional Paper 482, 52 p., 6 sheets, various scales.

Weber, F.R., Wheeler, K.L., Rinehart, C.D., Chapman, R.M., and Blodgett, R.B., 1992, Geologic map of the Livengood Quadrangle, Alaska: U.S. Geological Survey Open-File Report 92-562, 20 p., 1 sheet, scale 1:250,000. 


\section{Appendix A}

Photographs of bedrock at rock discontinuity measurement stations 
A1. Station 1 joint sets, beneath the Yukon River bridge.
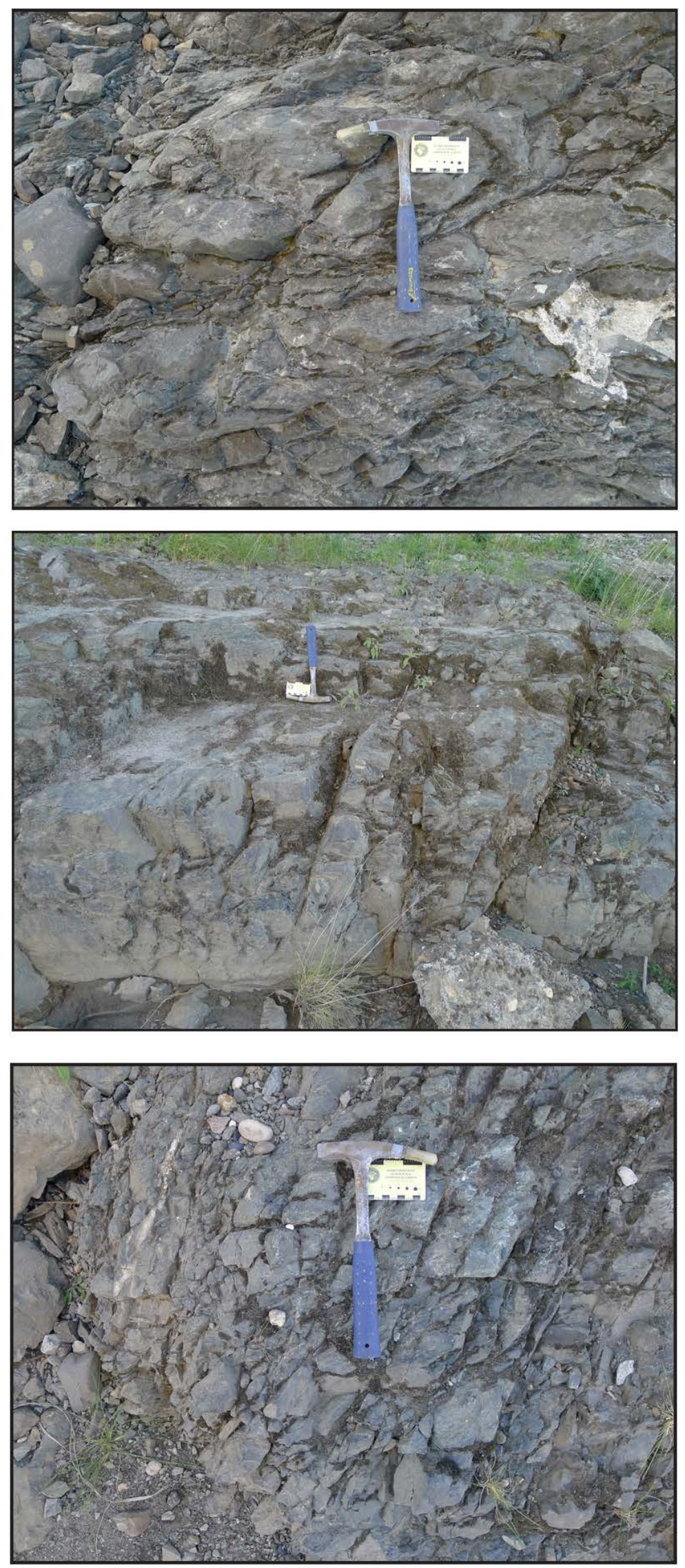

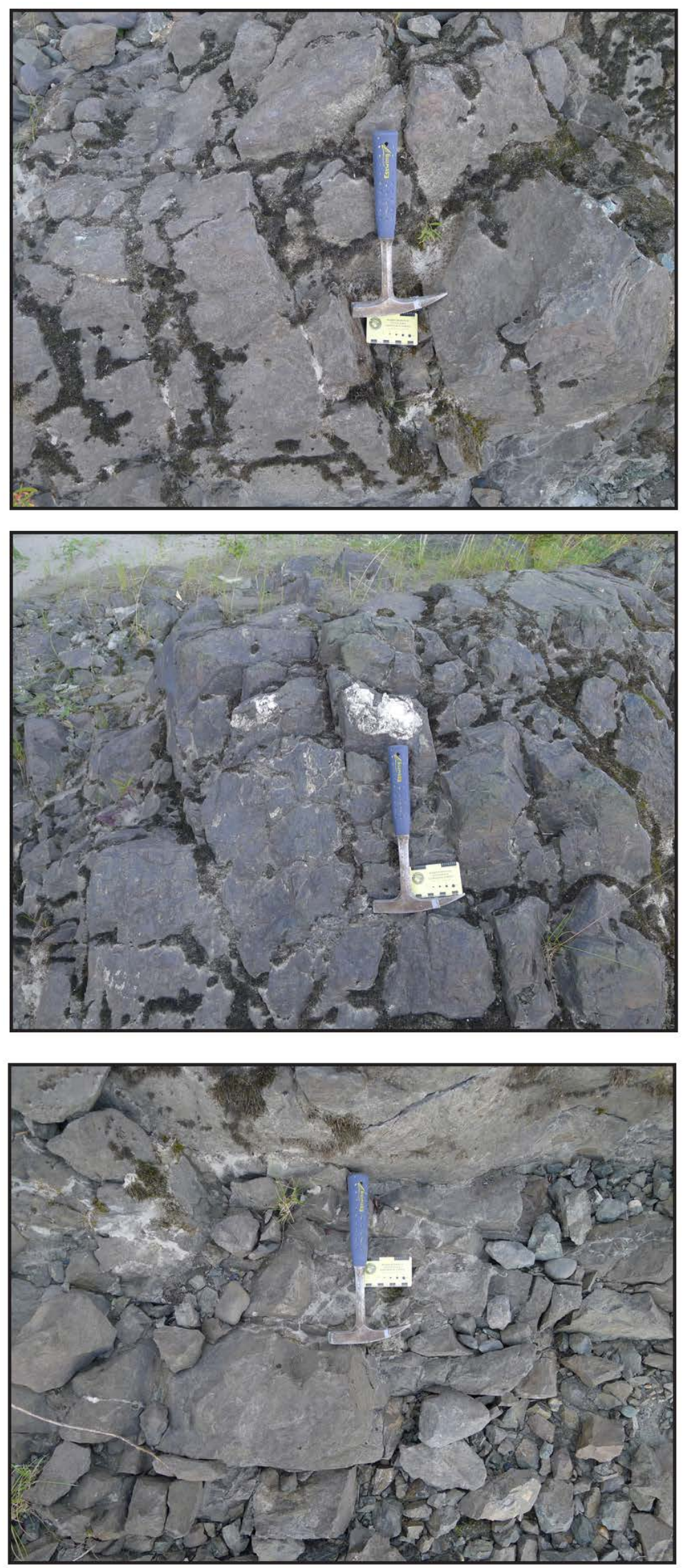

A2. Station 2 joint sets, 75 feet west of the Yukon River bridge. 
A3. Station 3 joint sets, 150 feet west of the Yukon River bridge.
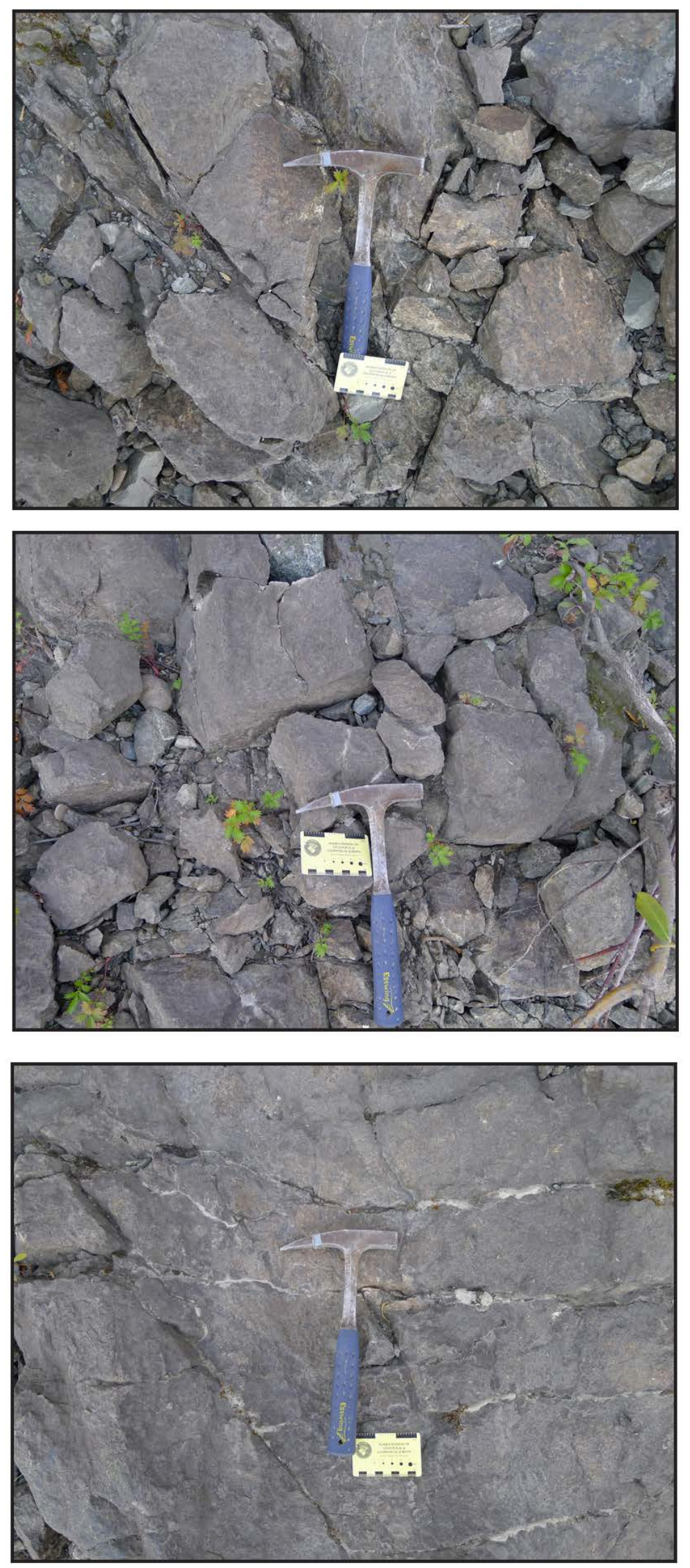

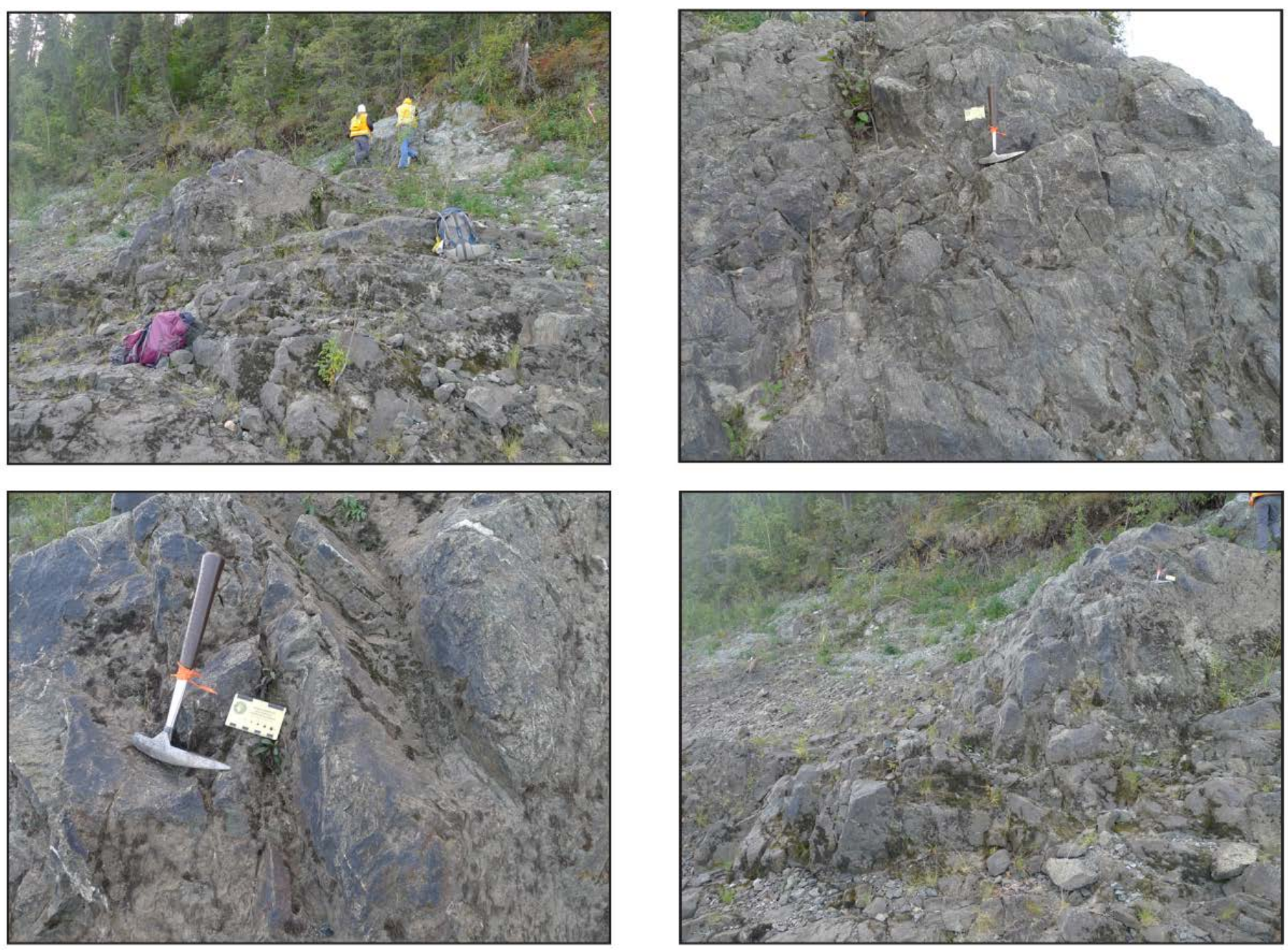

A4. Station 4a joint sets, 250 feet west of the Yukon River bridge and directly east of landslide. 
A5. Station $4 b$ joint sets, 250 feet west of the

Yukon River bridge and east of the landslide.
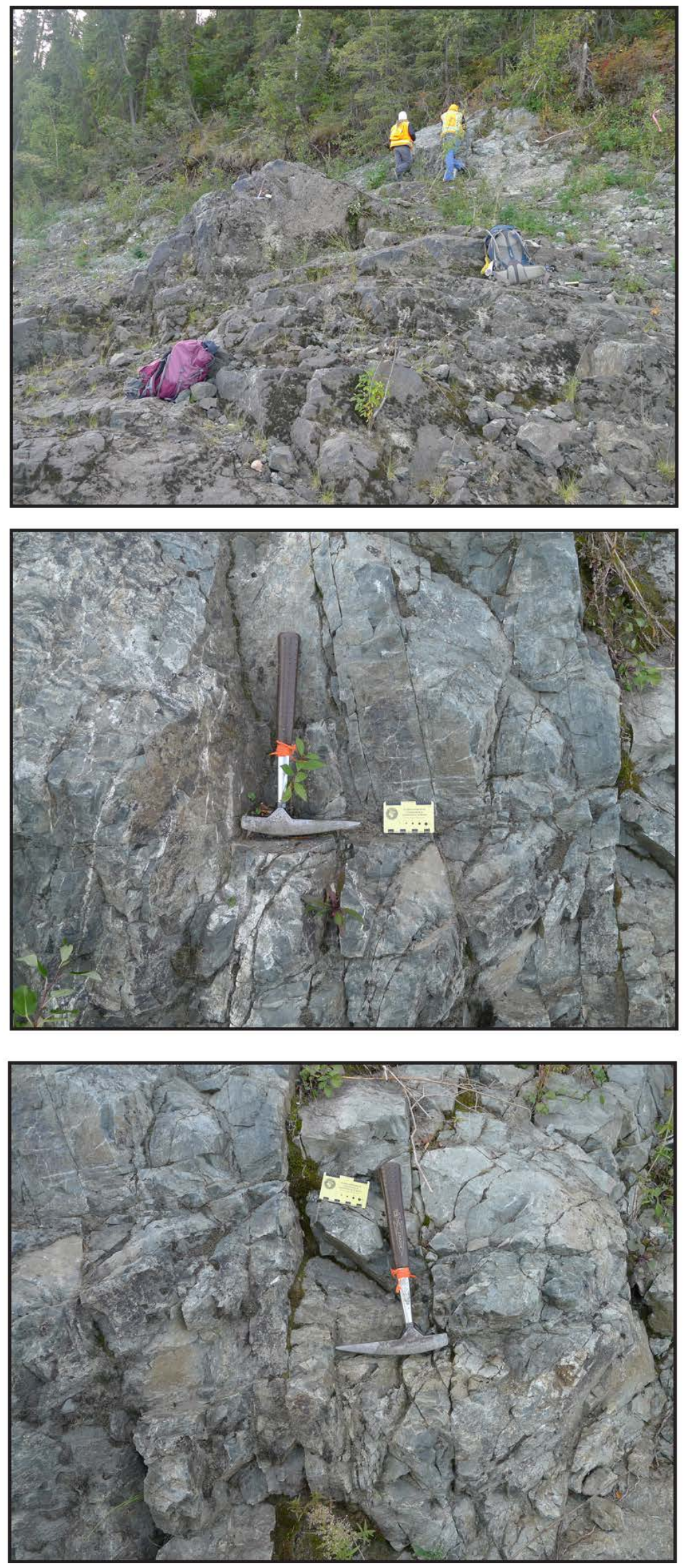


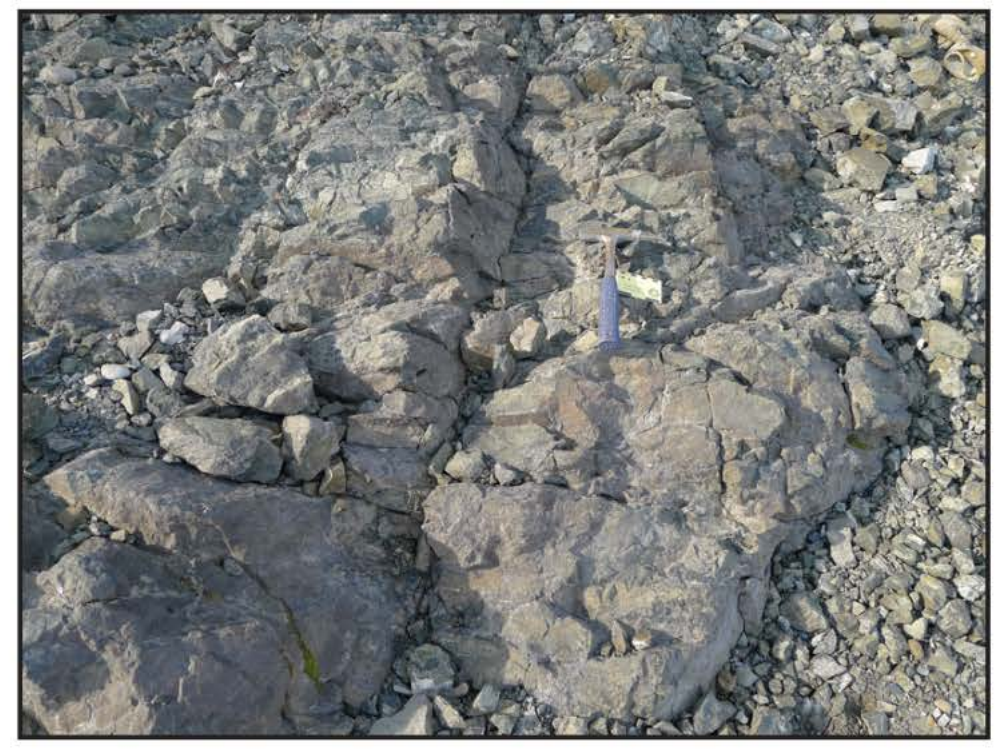

A6. Station 5 a joint sets, 600 feet west of the Yukon River bridge and west of the landslide.
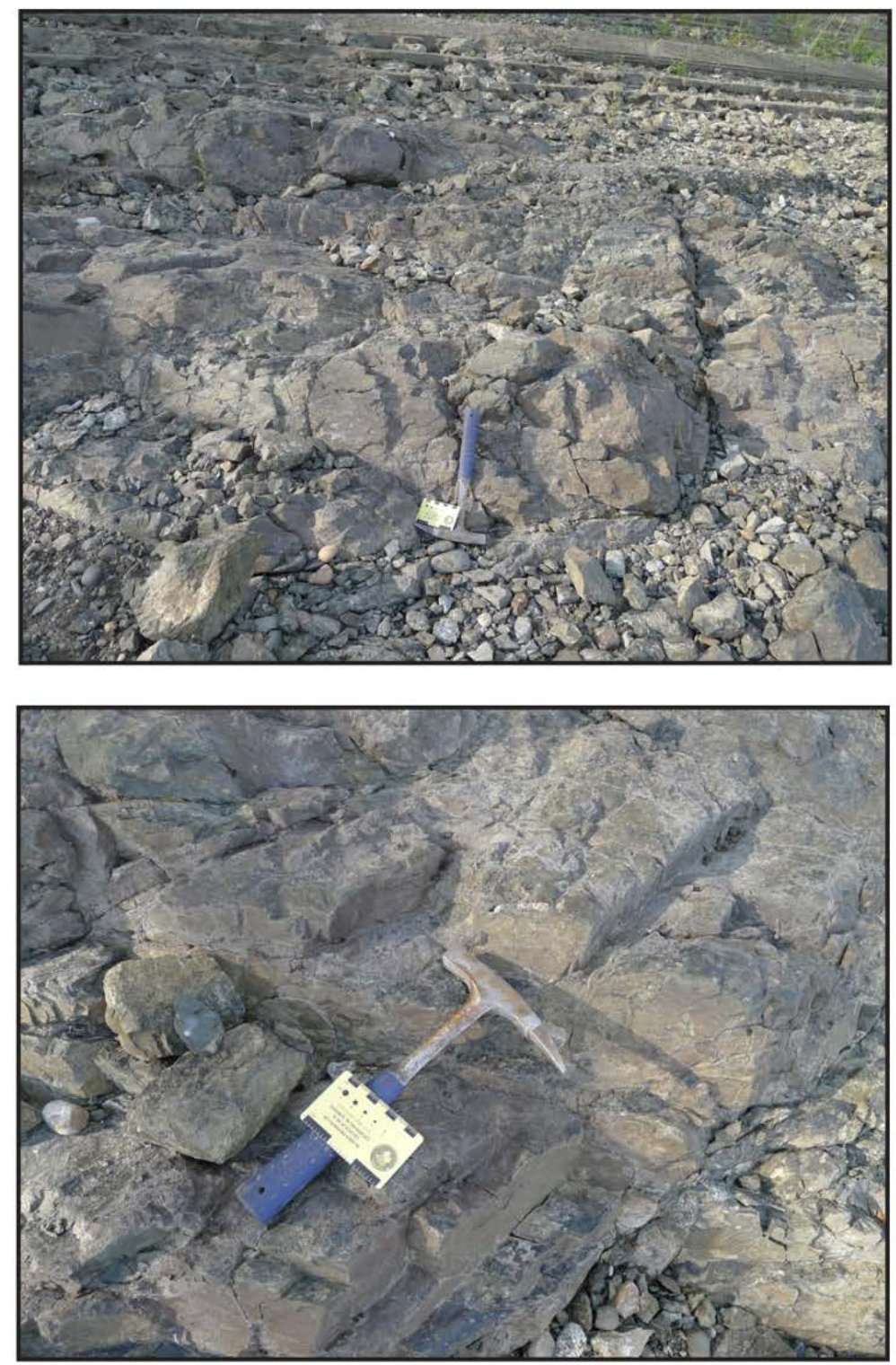



A7. Station $5 b$ joint sets, 600 feet west of the Yukon River bridge and west of the landslide. 

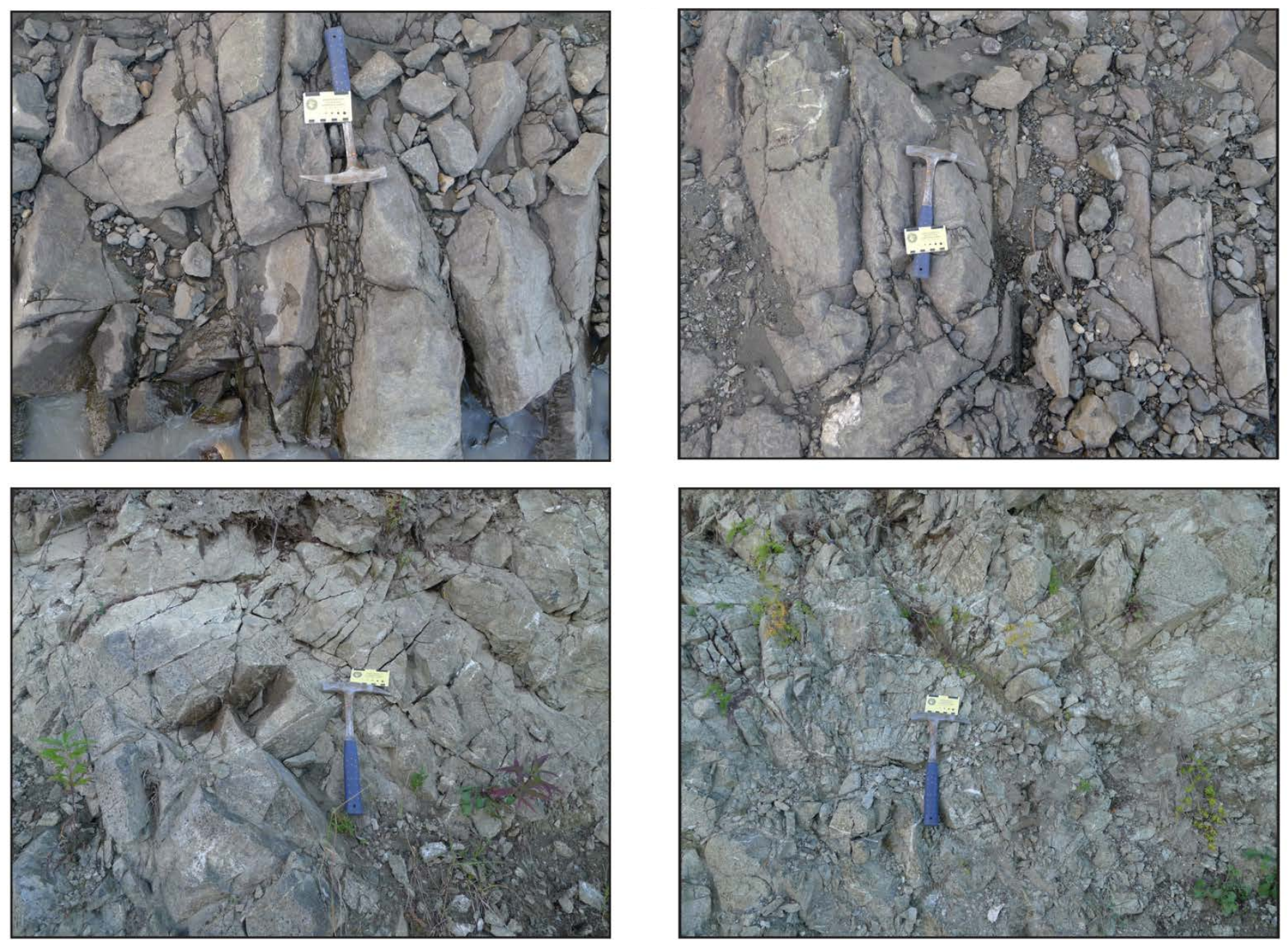

A8. Station 6 joint sets, 650 feet west of the Yukon River bridge and west of the landslide. 

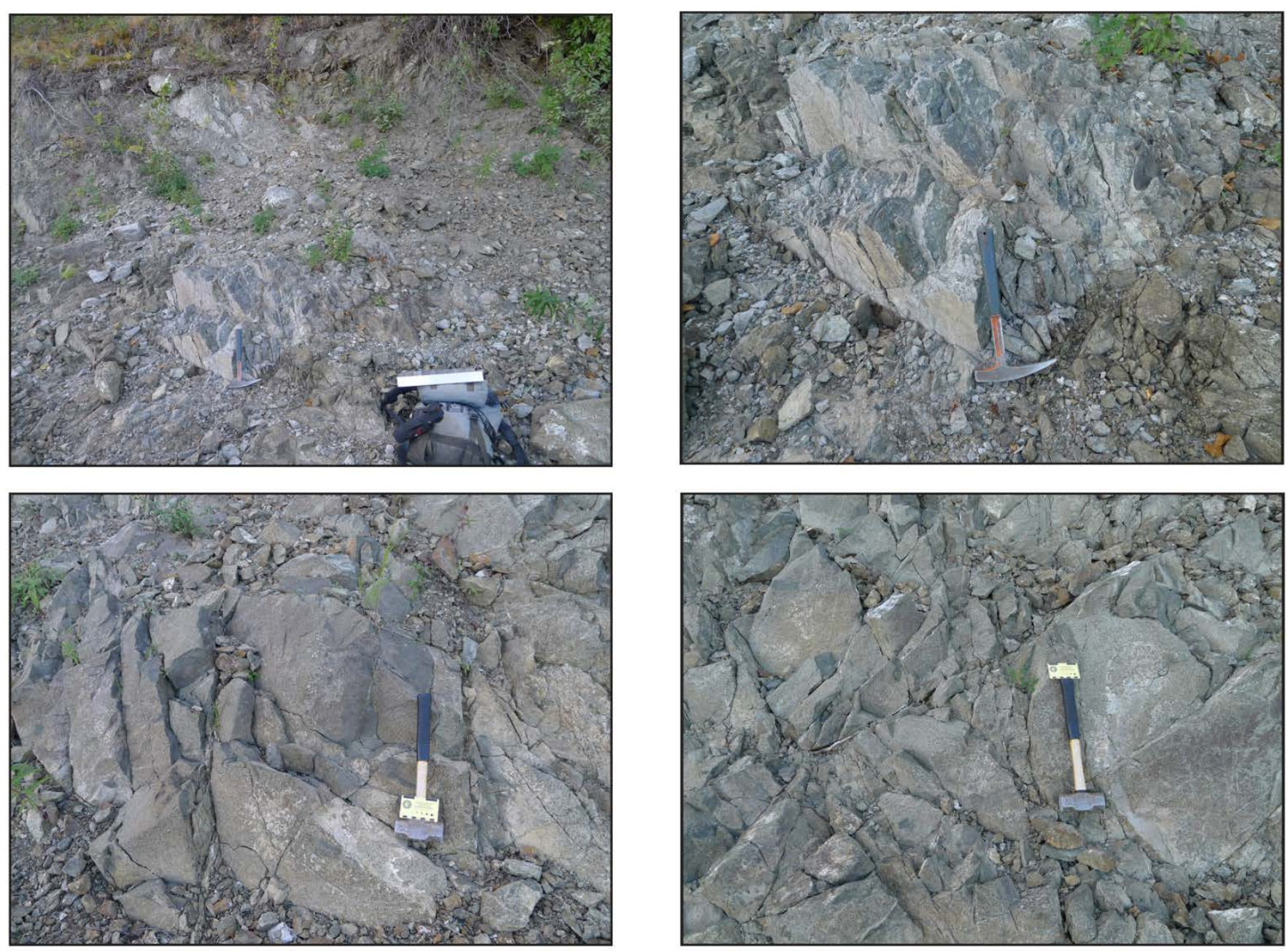

A9. Station 7 joint sets, between 770 and 800 feet west of the Yukon River bridge and west of the landslide. 

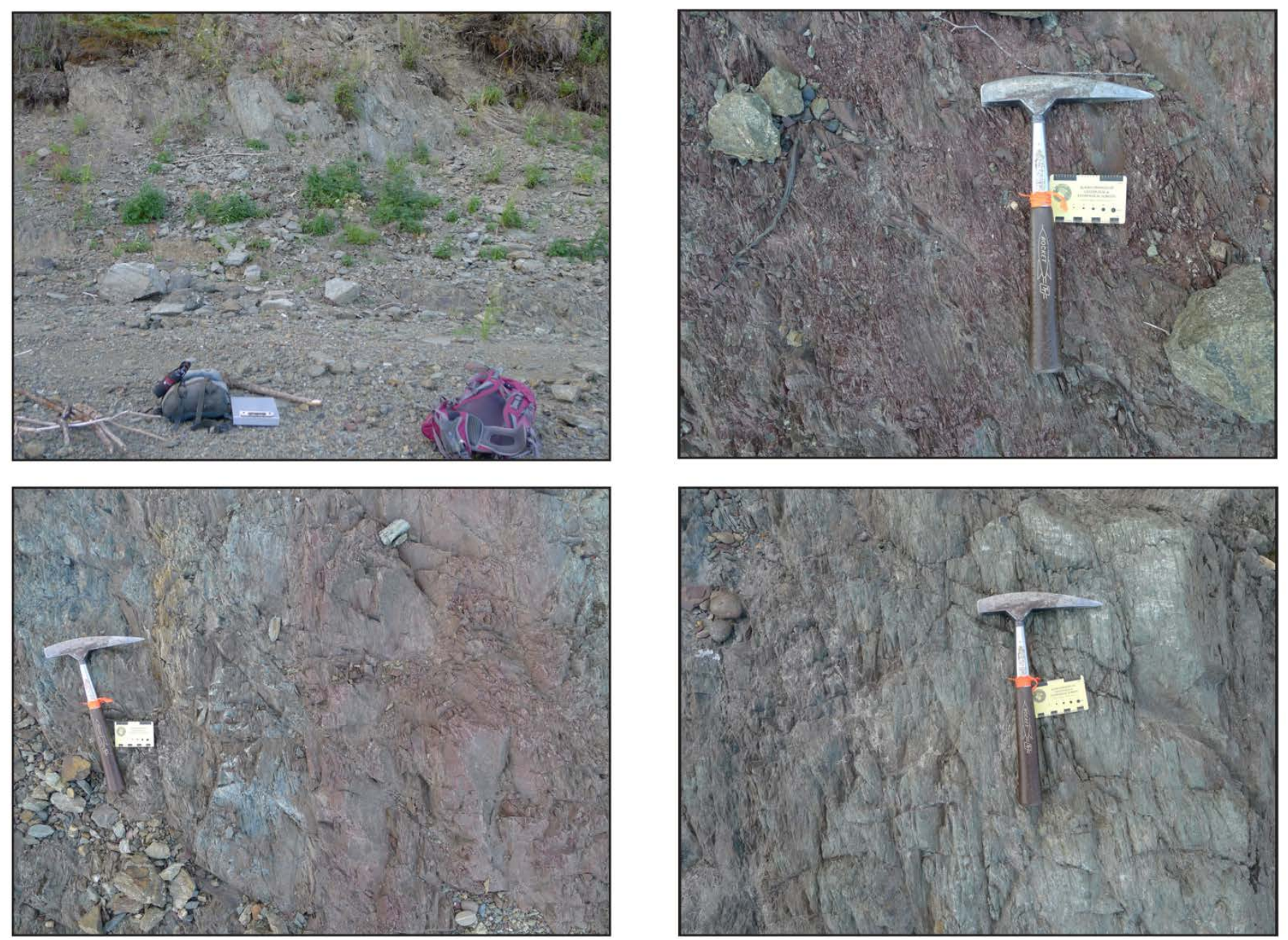

A10. Station 8 joint sets, 1,000 feet west of the Yukon River bridge and west of the landslide. 
A11. Station 9 joint sets, between 100 and 150 feet east of the Yukon River bridge.
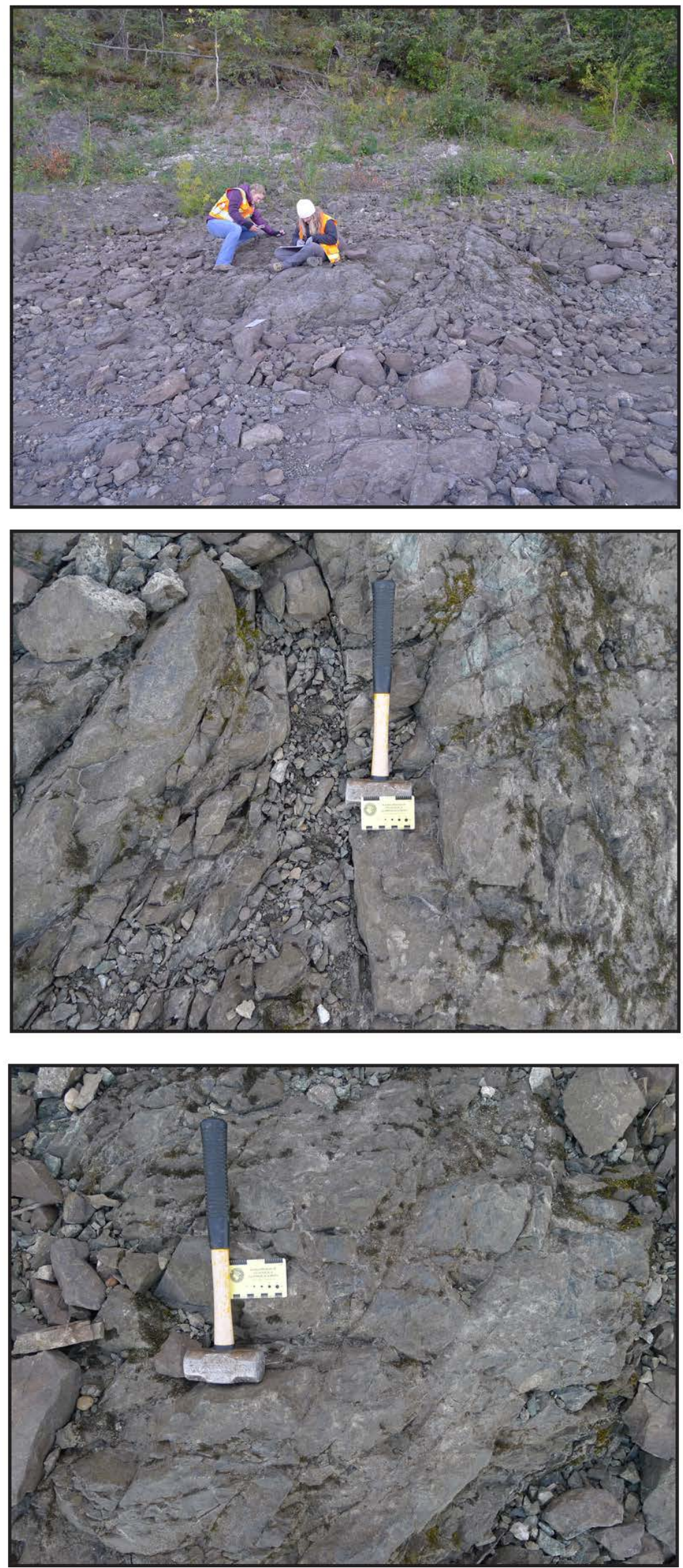

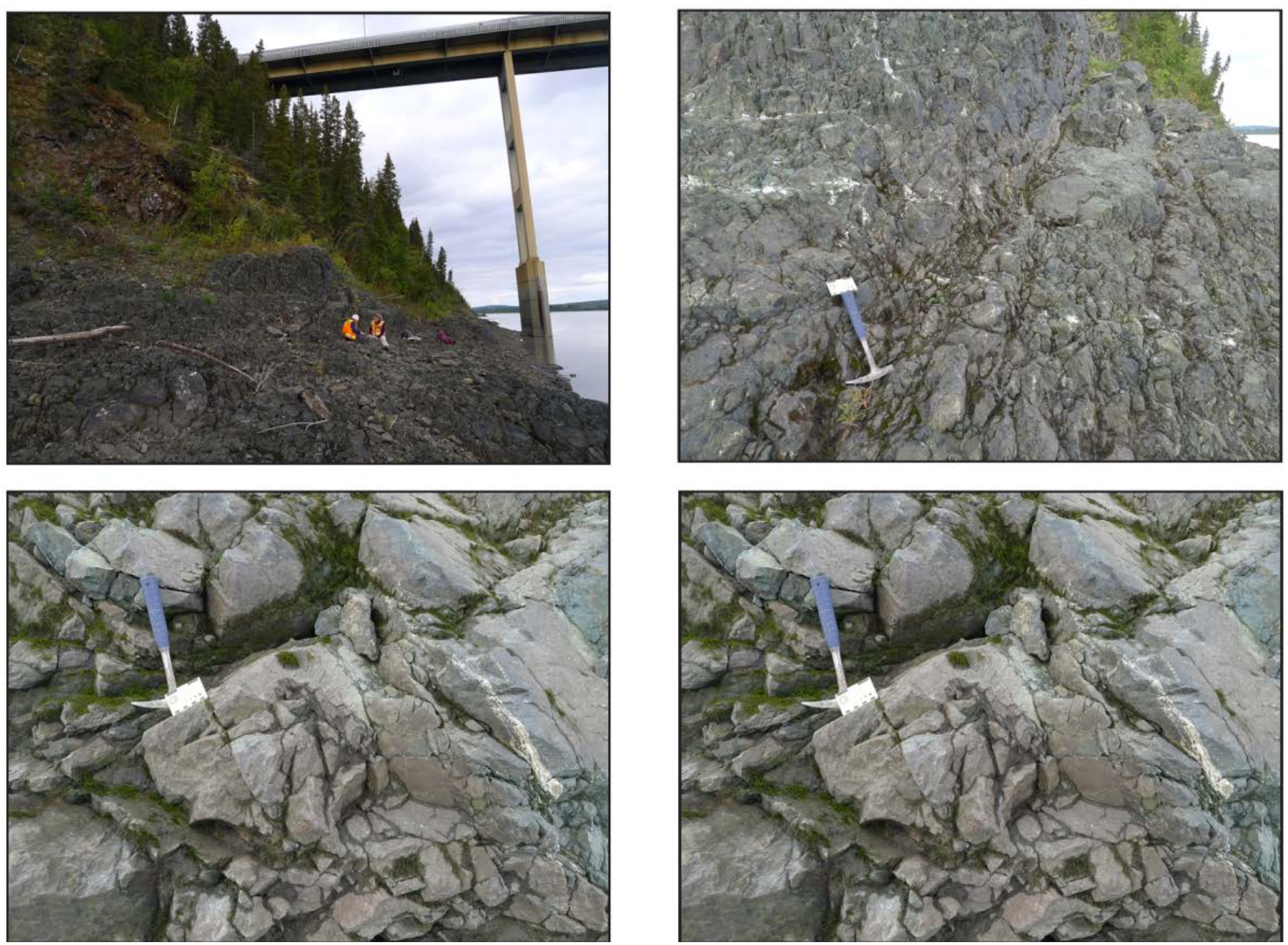

A12. Station 10 joint sets, between 200 and 250 feet east of the Yukon River bridge. 
A13. Station 11 joint sets, between 625 and 675 feet east of the Yukon River bridge.
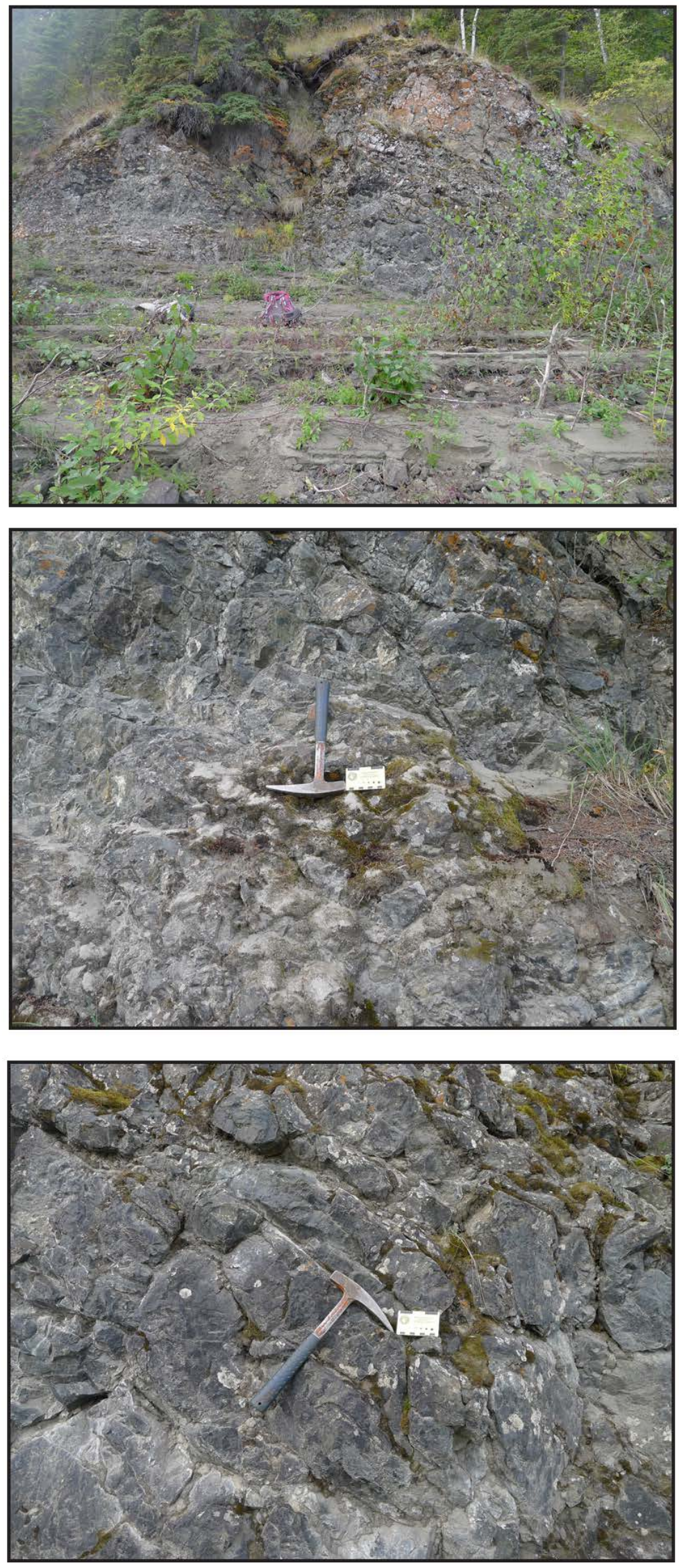


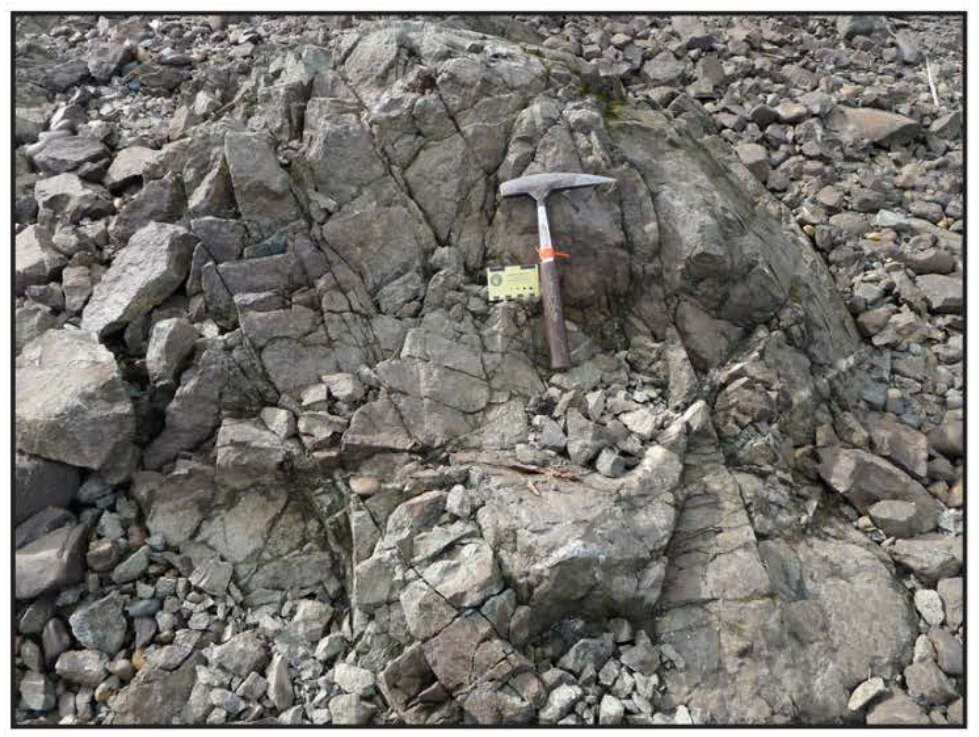

A14. Station 12 joint sets, between 850 and 900 feet east of the Yukon River bridge.
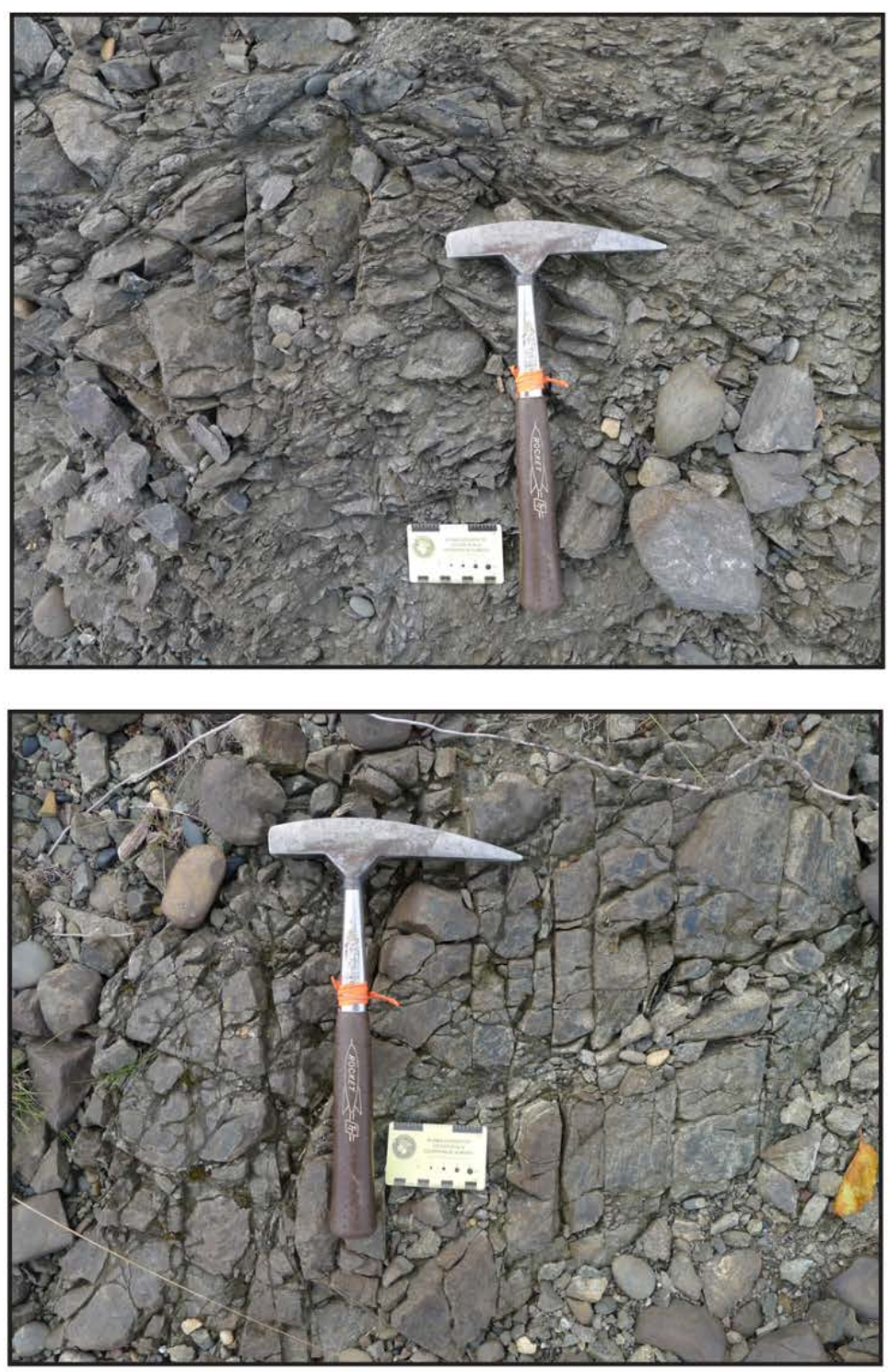
A15. Station 13 joint sets, approximately 1,150 feet west of the Yukon River bridge (promiment outcrop that extends into the river).
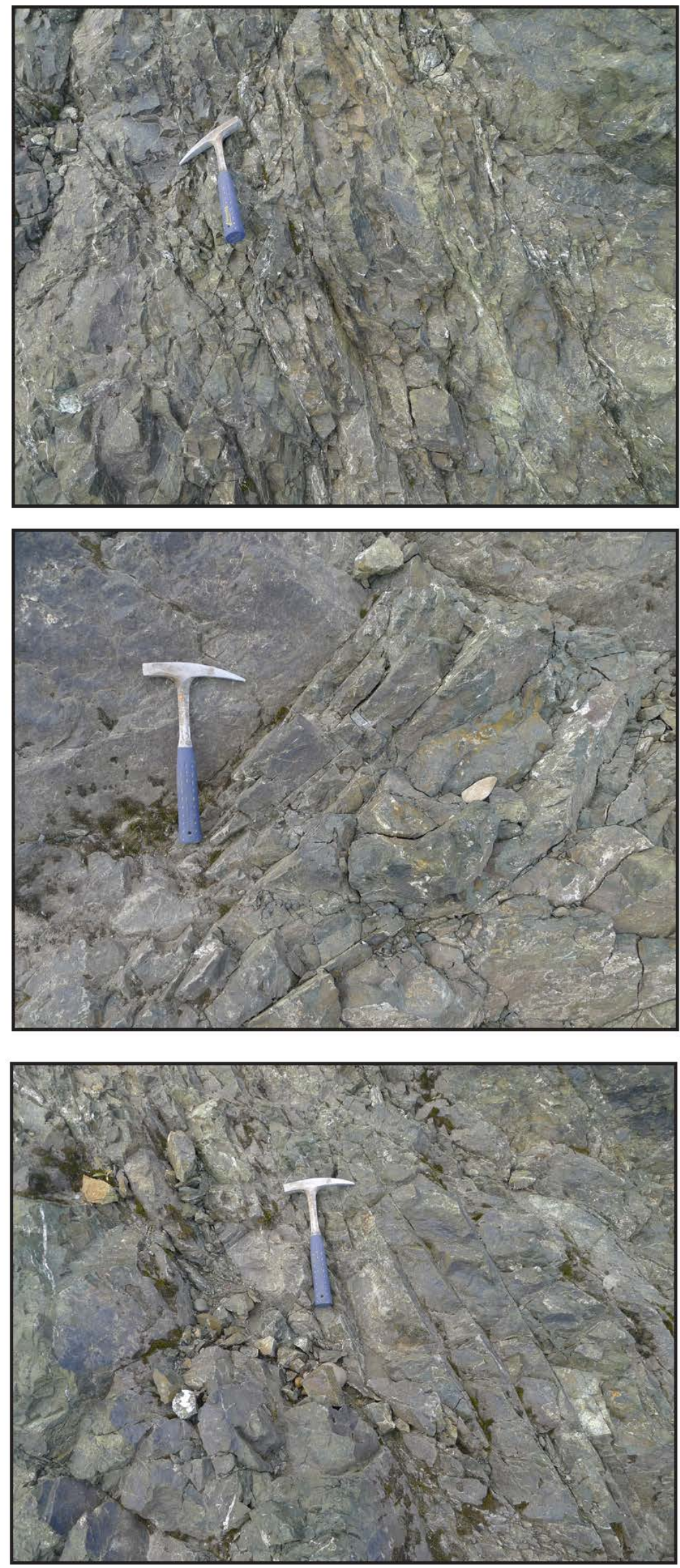


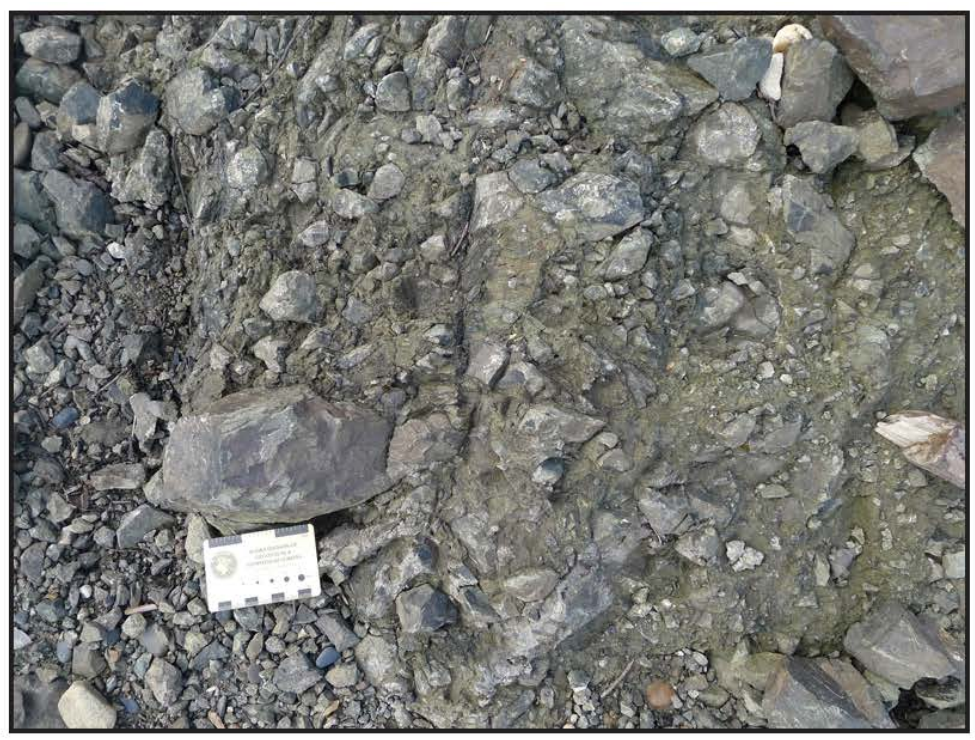

A16. Area between Stations 10 and 11, joint sets in sheared graywacke, approximately 300 to 475 feet east of the Yukon River bridge.
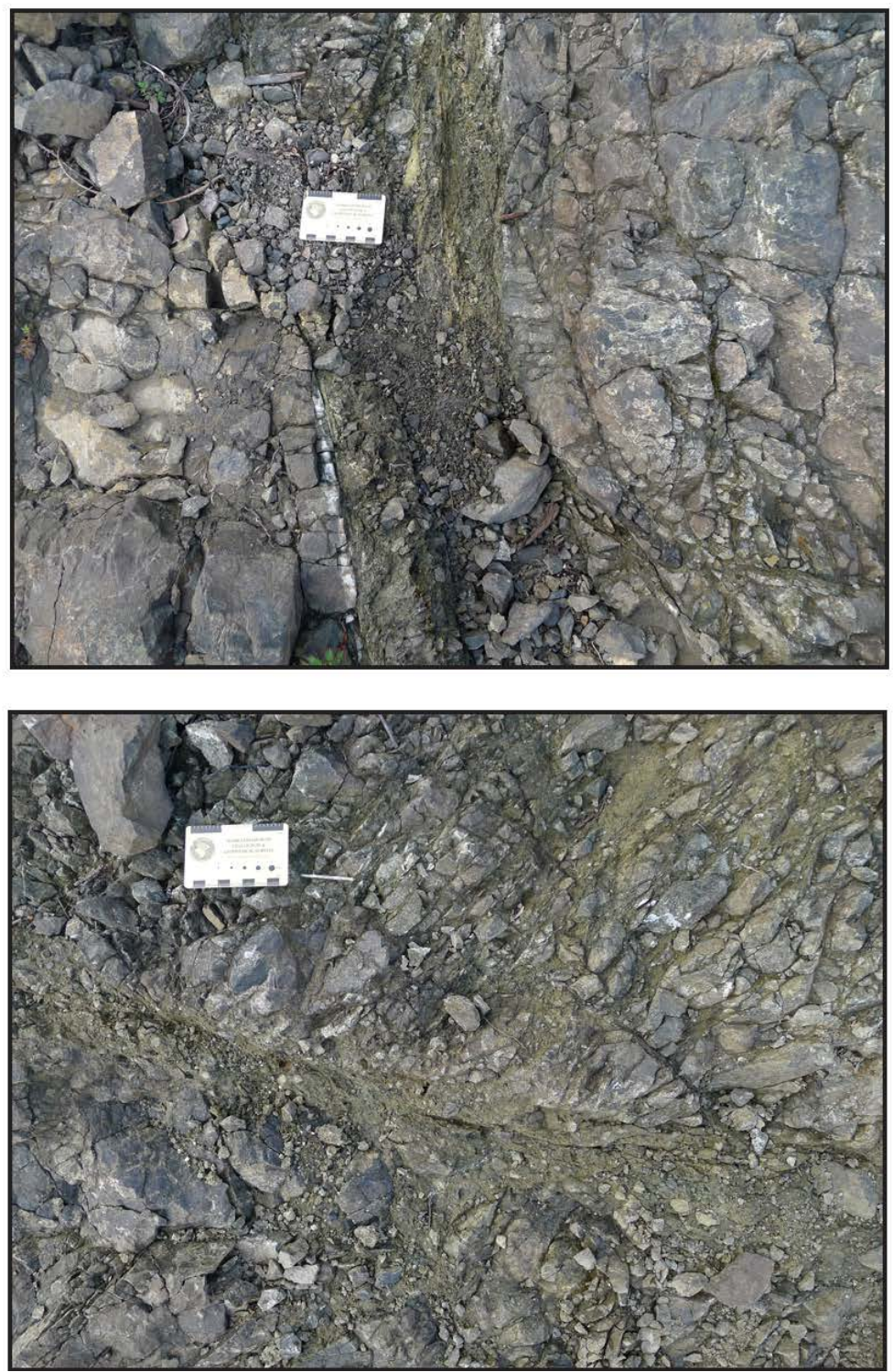


\section{Appendix B}

Field evaluation sheets 


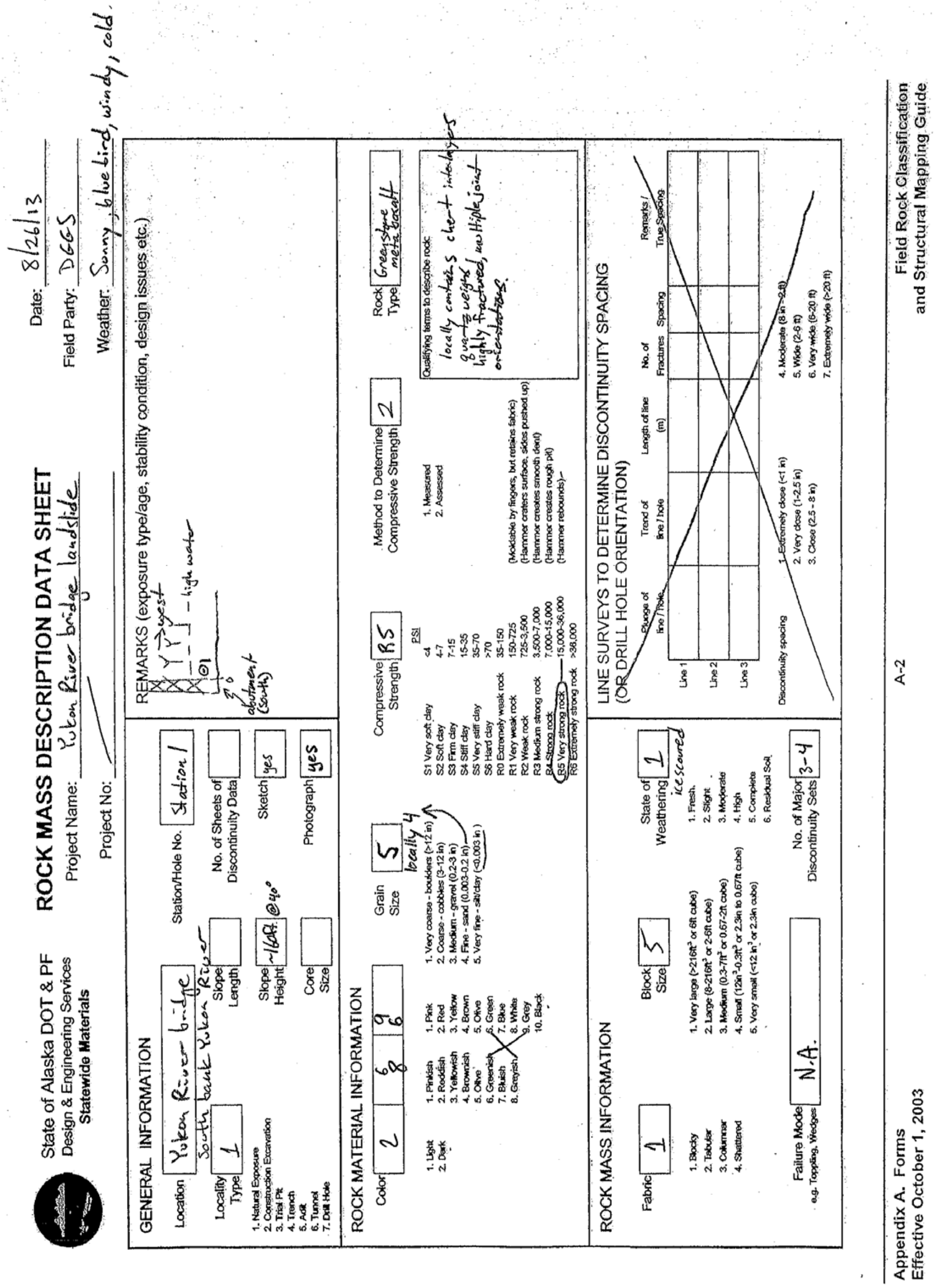




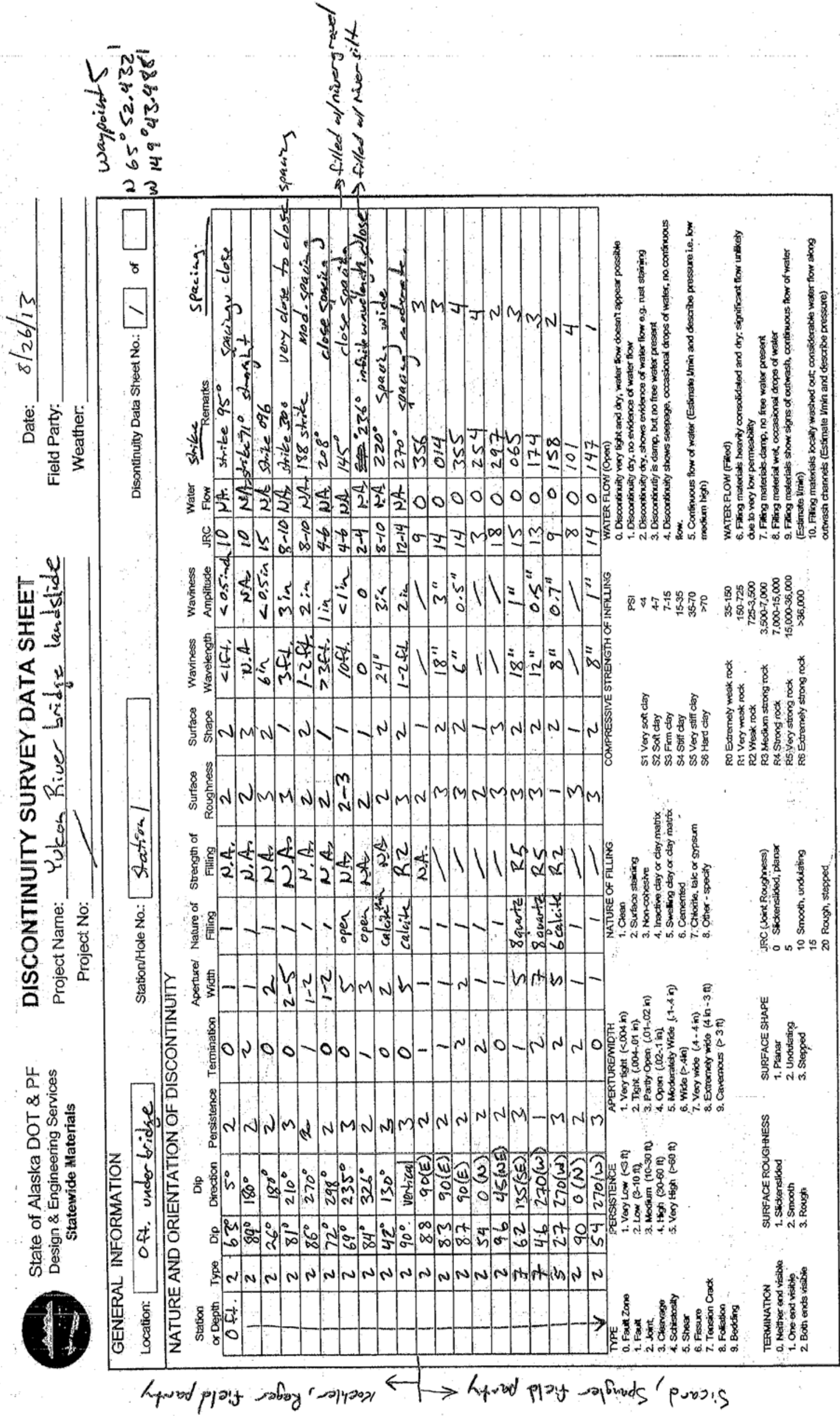

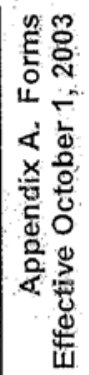

$\frac{\eta}{4}$ 


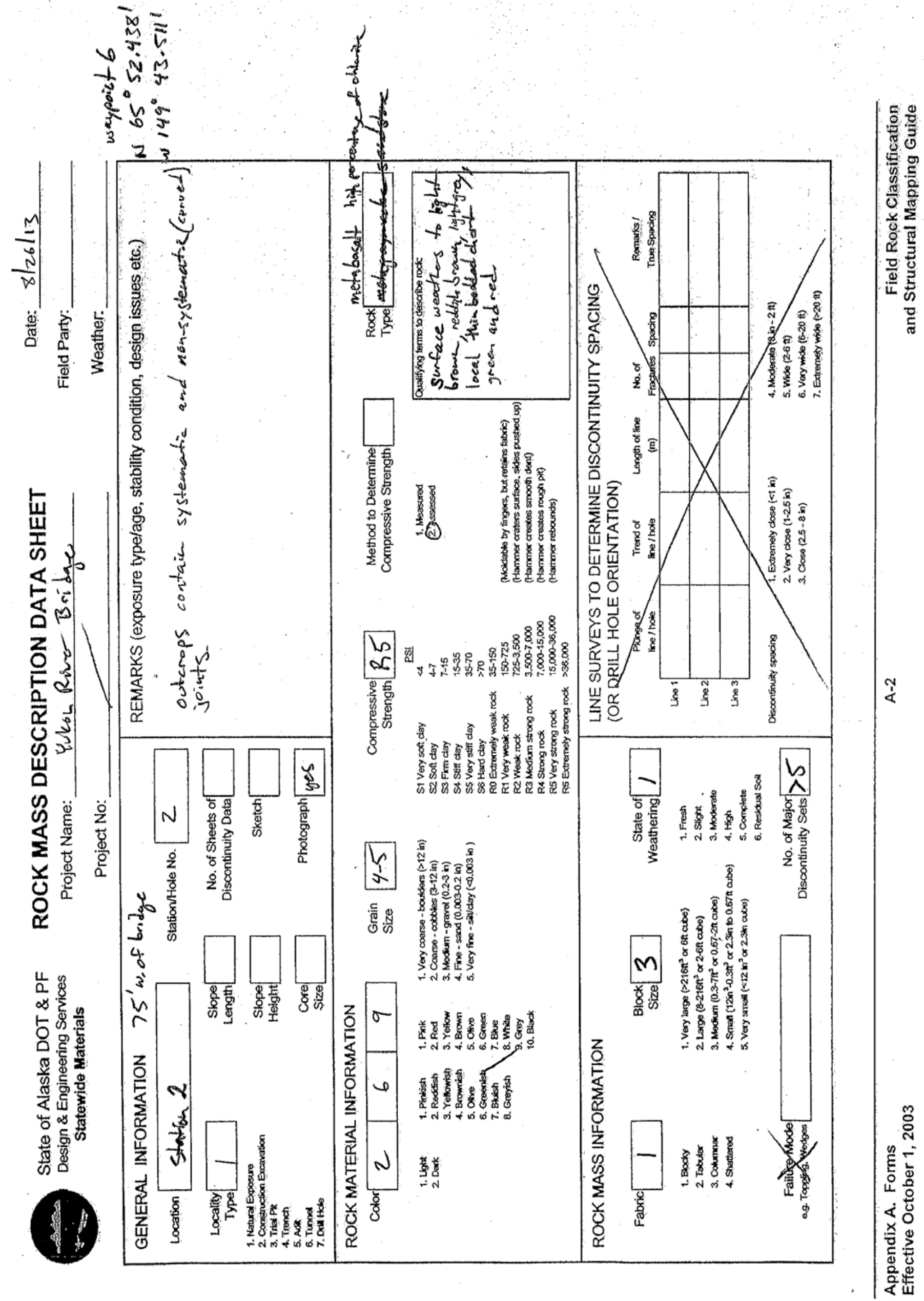




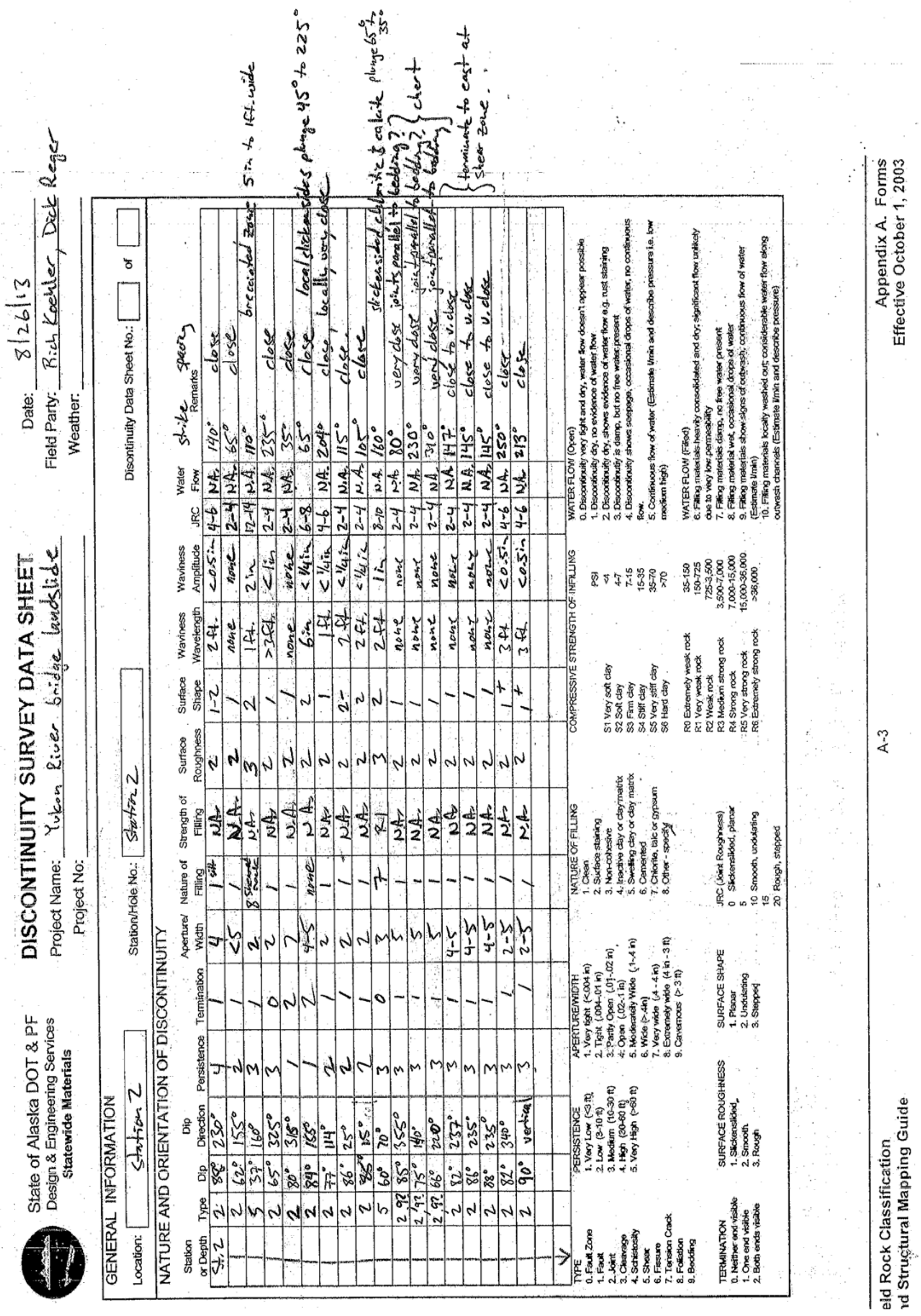




$$
\begin{aligned}
& +\frac{0}{2} \\
& \text { \# is } \frac{\pi}{\pi} \\
& \text { to。 } \\
& 30 \frac{\sigma}{0} \\
& \text { iा } 23
\end{aligned}
$$
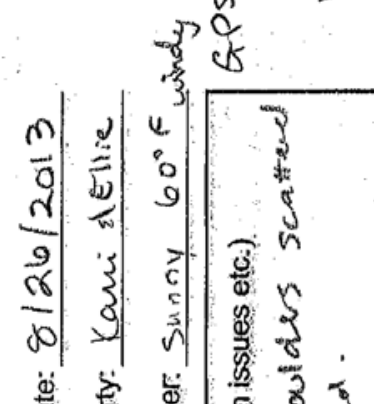

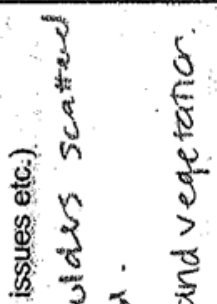

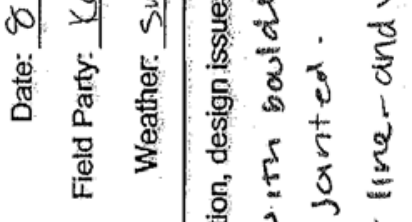
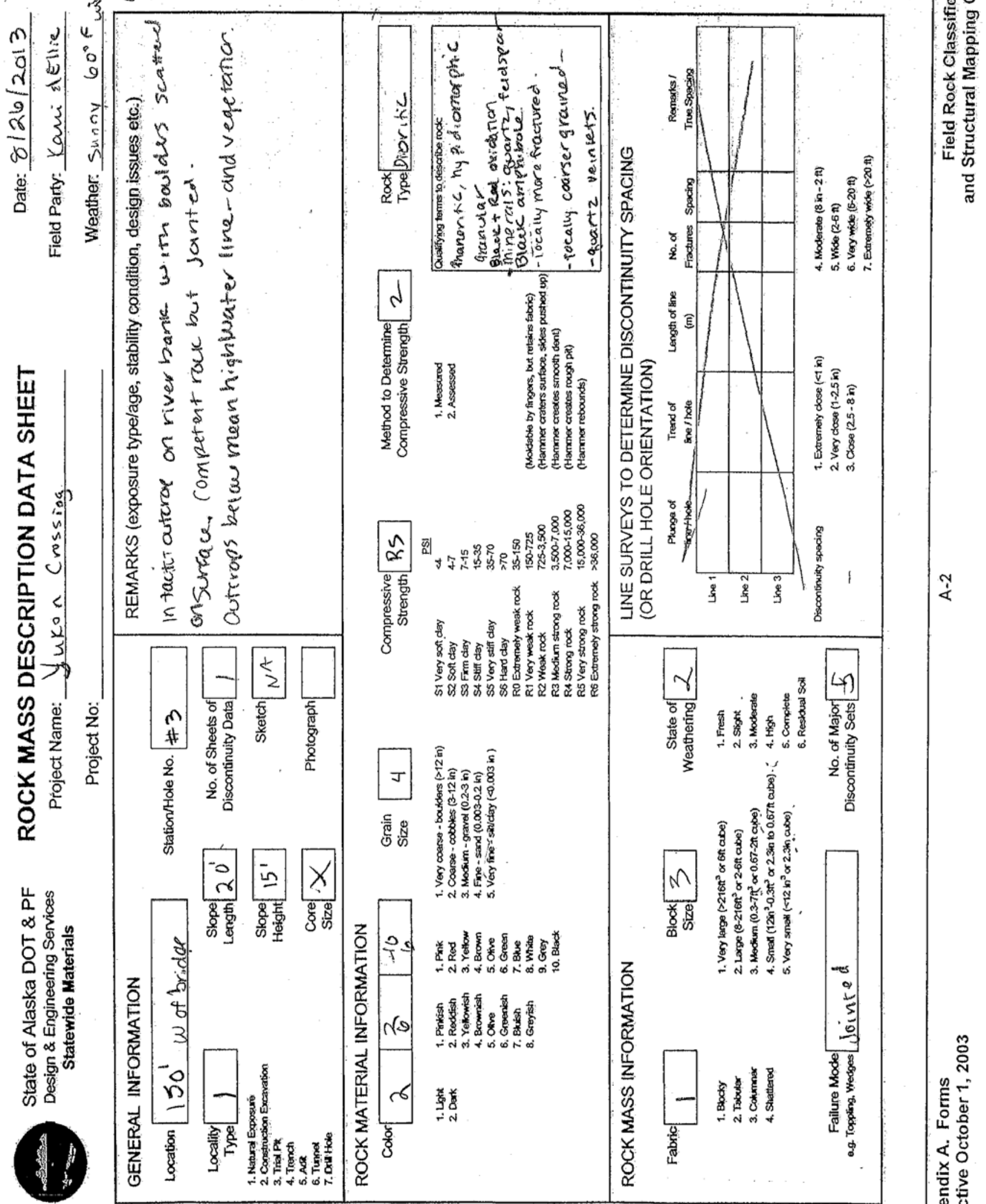

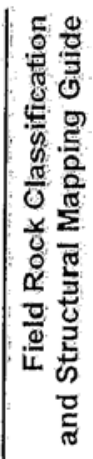

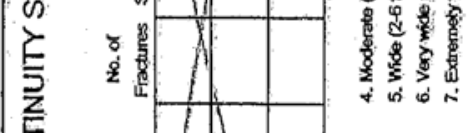

ঙั丶

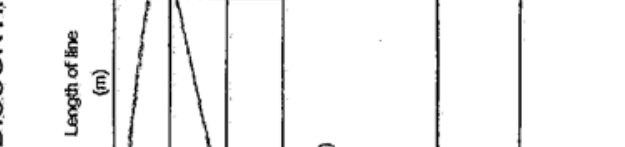

岂企
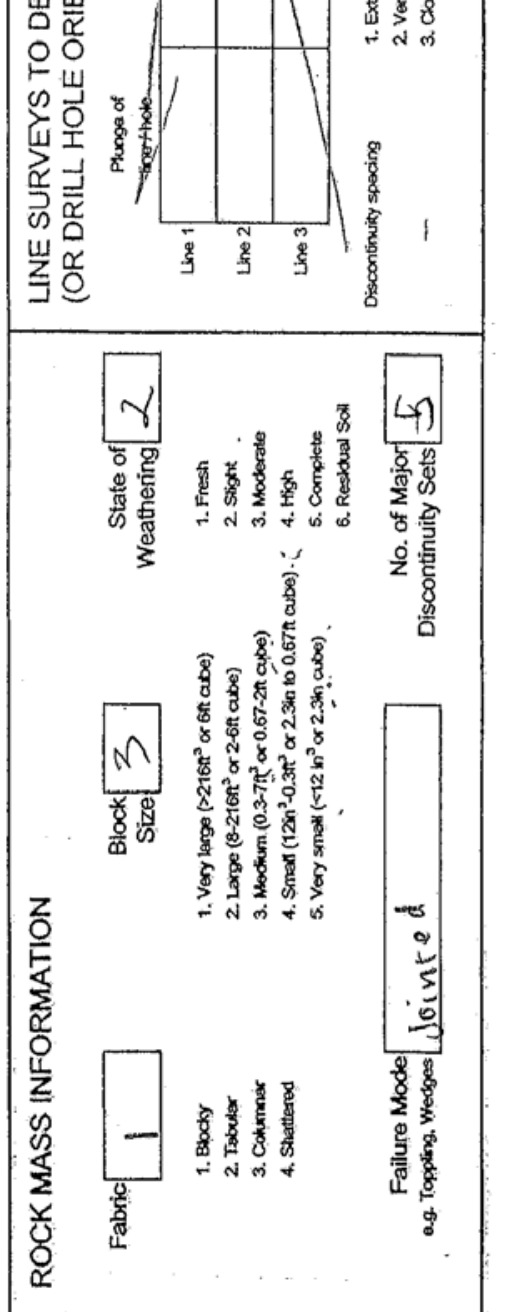

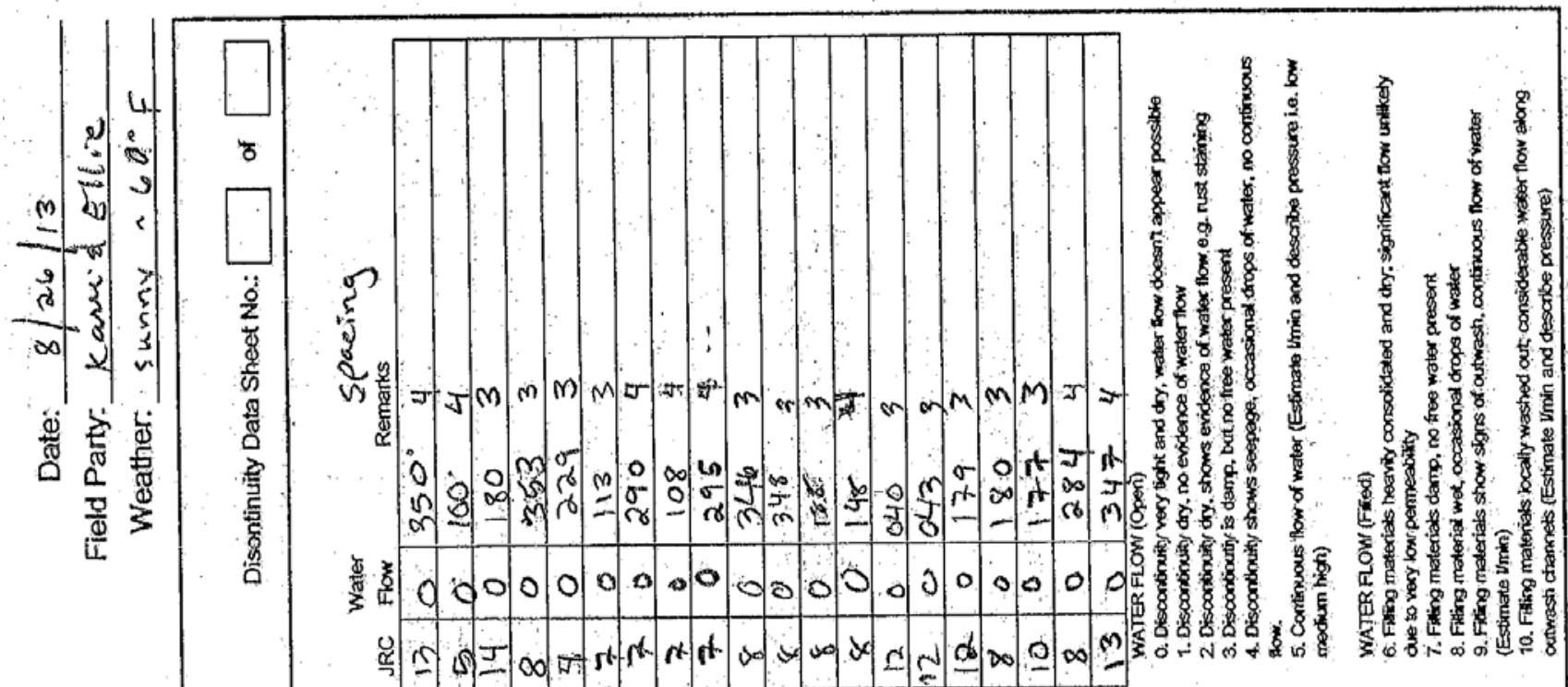

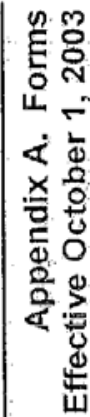

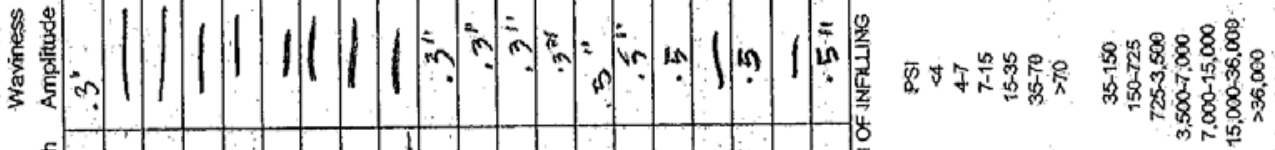

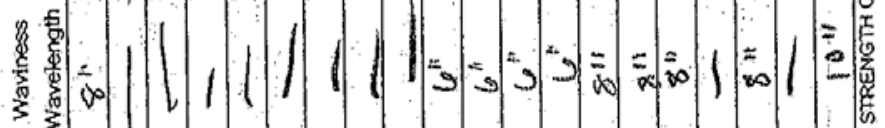

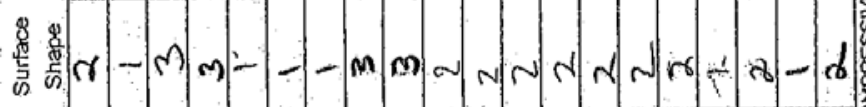

$5 \mathrm{~m} m \mathrm{mmm} m \mathrm{~mm} \mathrm{~m} / \mathrm{m} m \mathrm{~m} m$

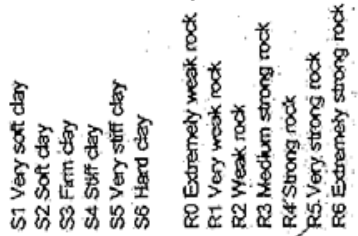

$\stackrel{?}{4}$

兽

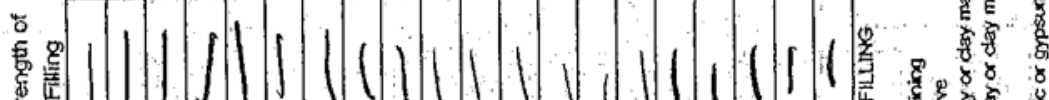

m

悹

$7 \%$

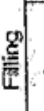

4 窟

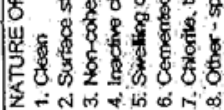

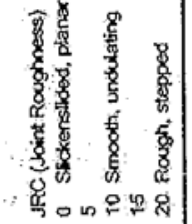

要

岸 \&

क :

它

(1)

\%

से

○吢

(1) 家

嗼

要离

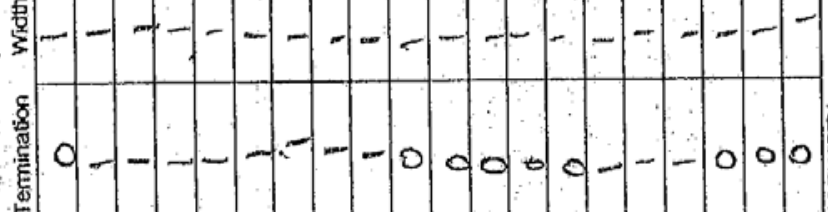

द $\frac{a}{2}$

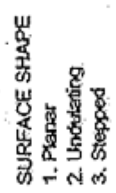

年

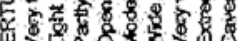

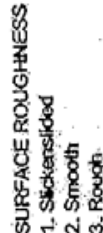

作

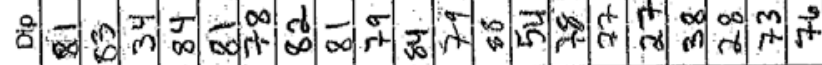

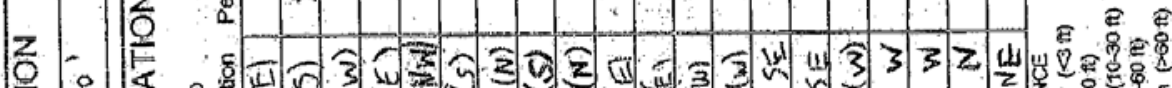

$\sum_{\bar{\alpha}}^{\frac{5}{\alpha}} \frac{1}{i}$

贻

$\frac{15}{2}$

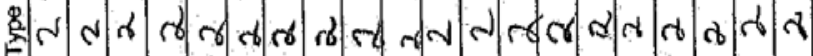

§

8 i

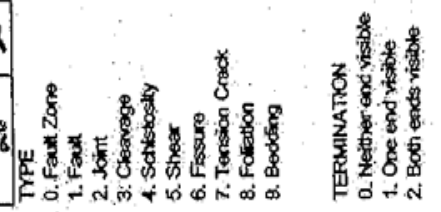


4
0
+
+
+3
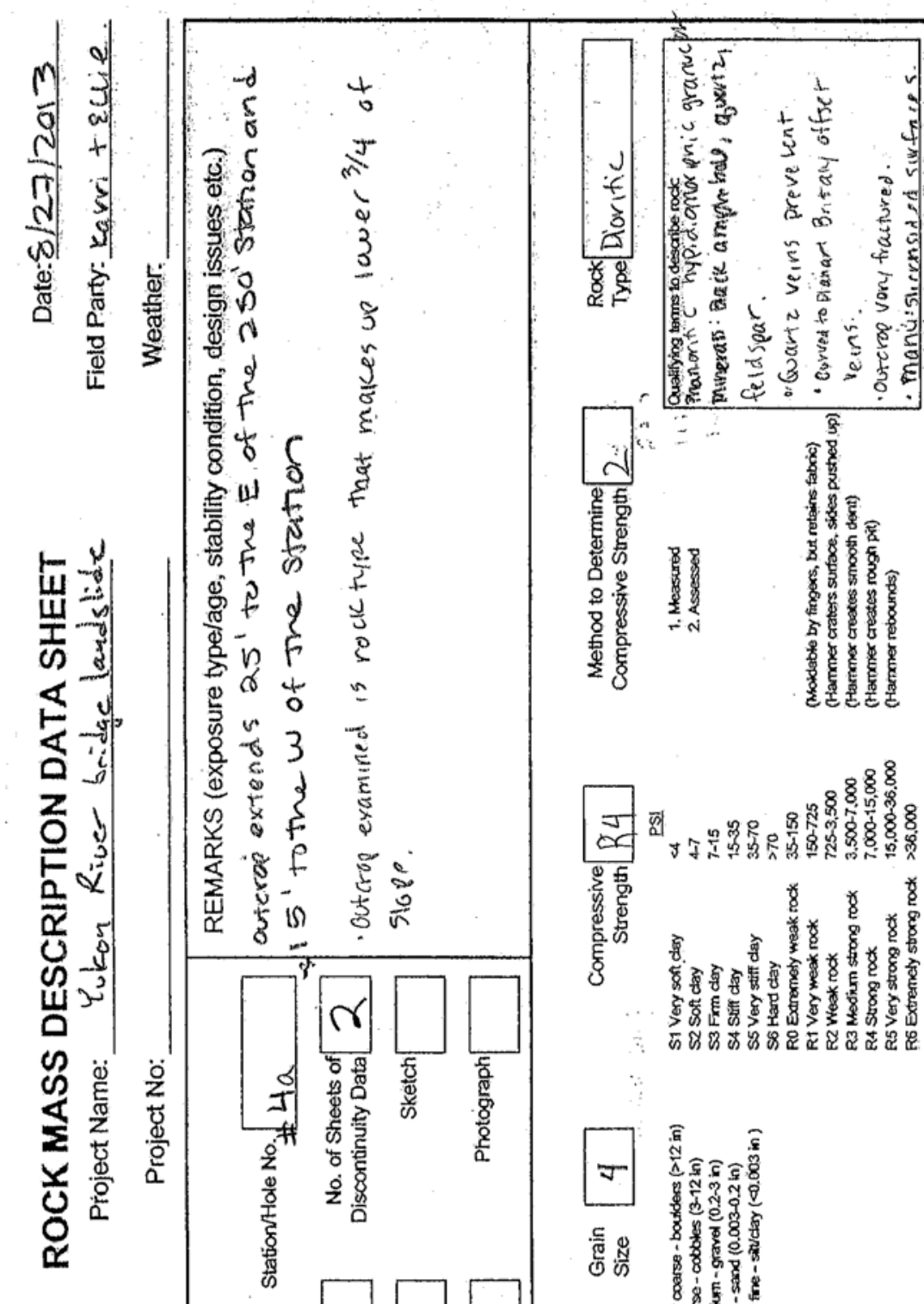


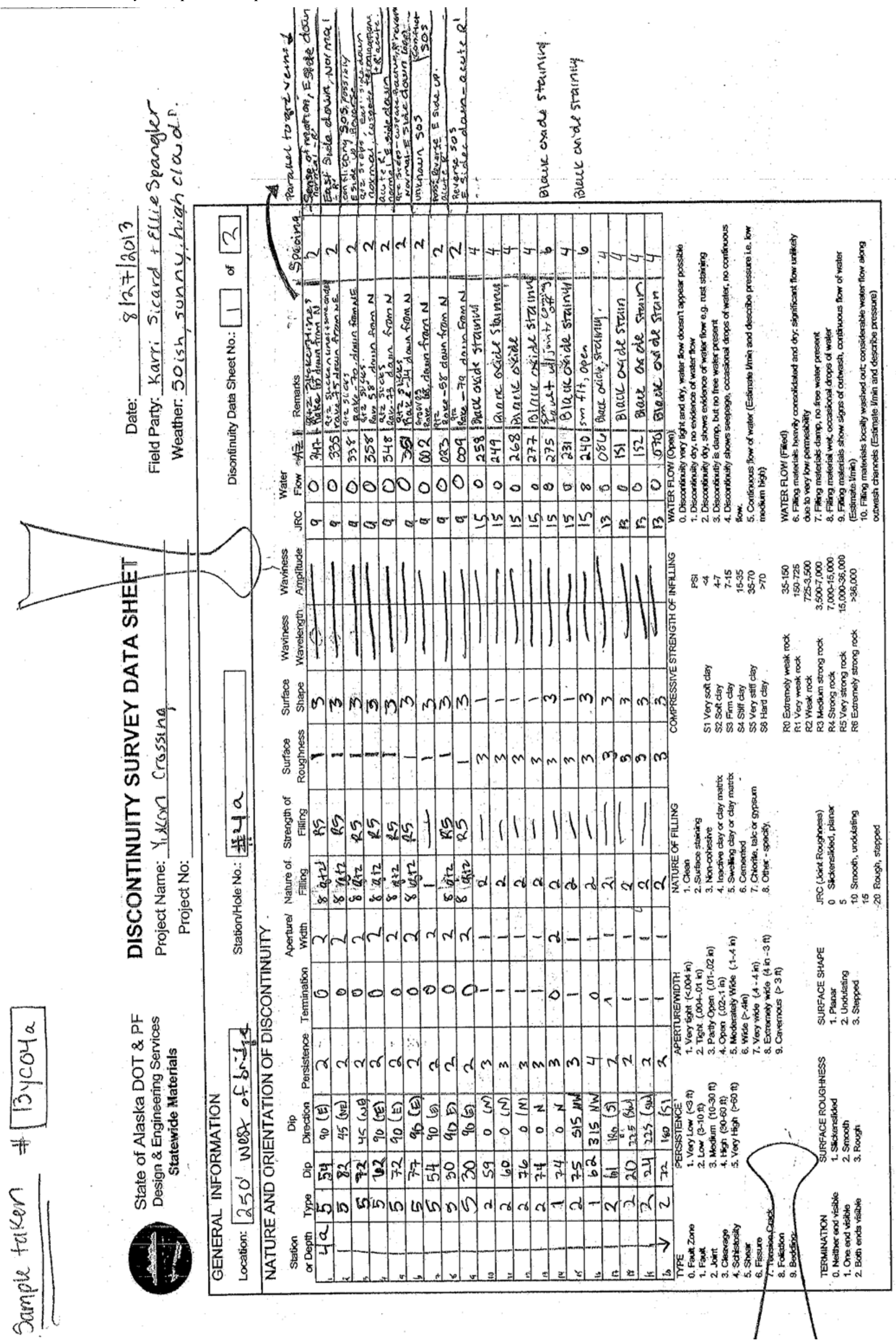

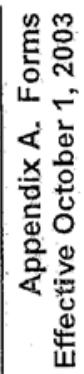




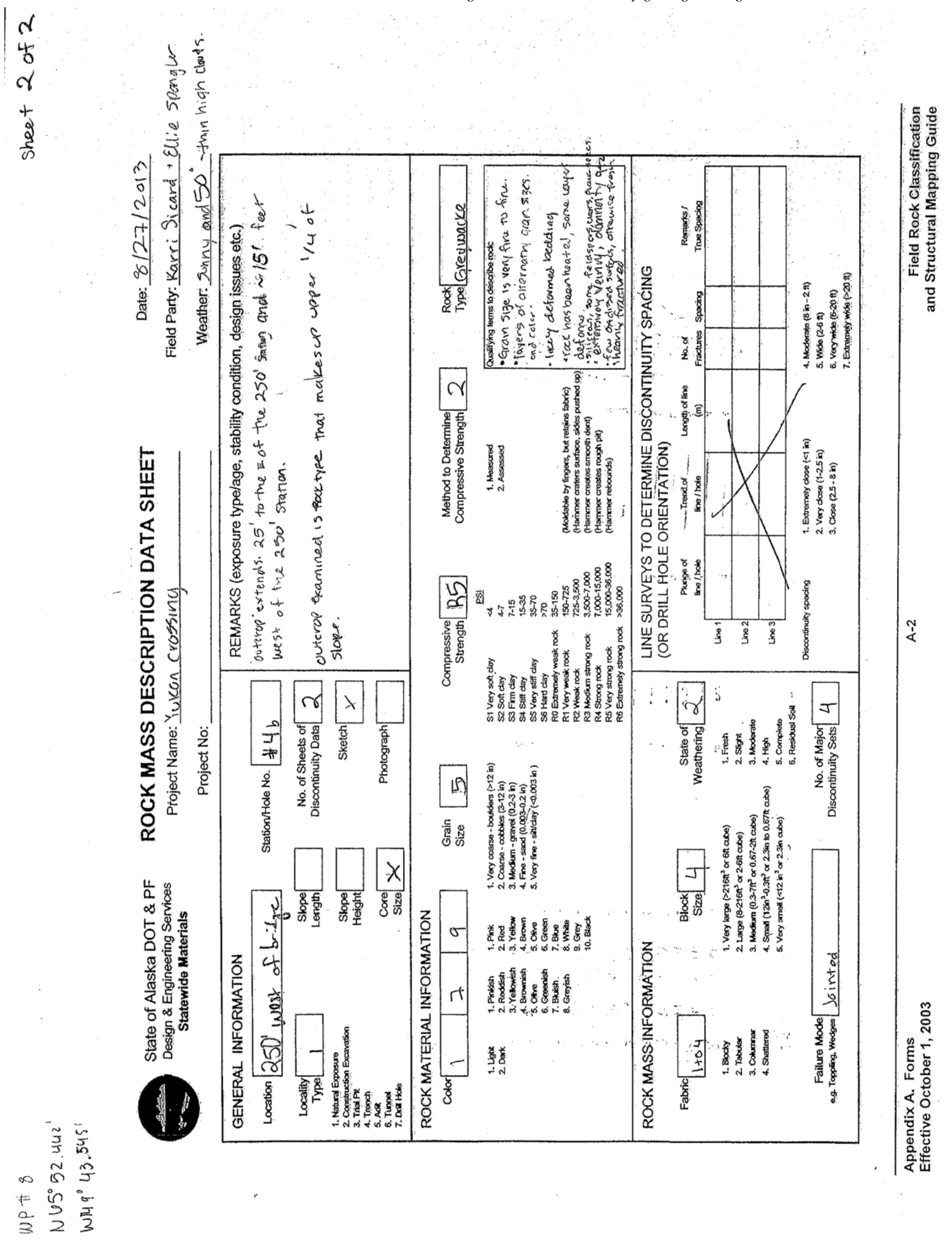




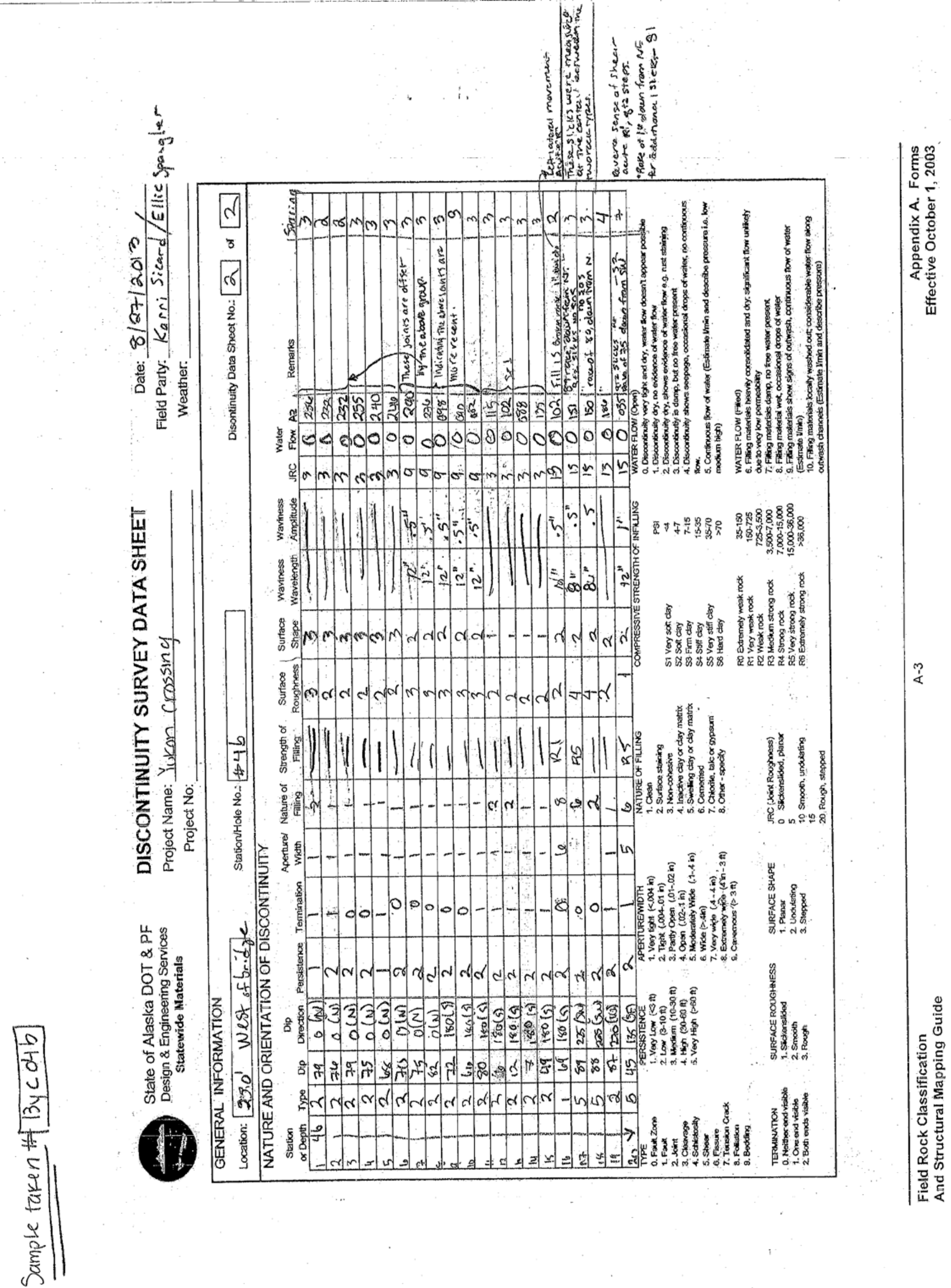



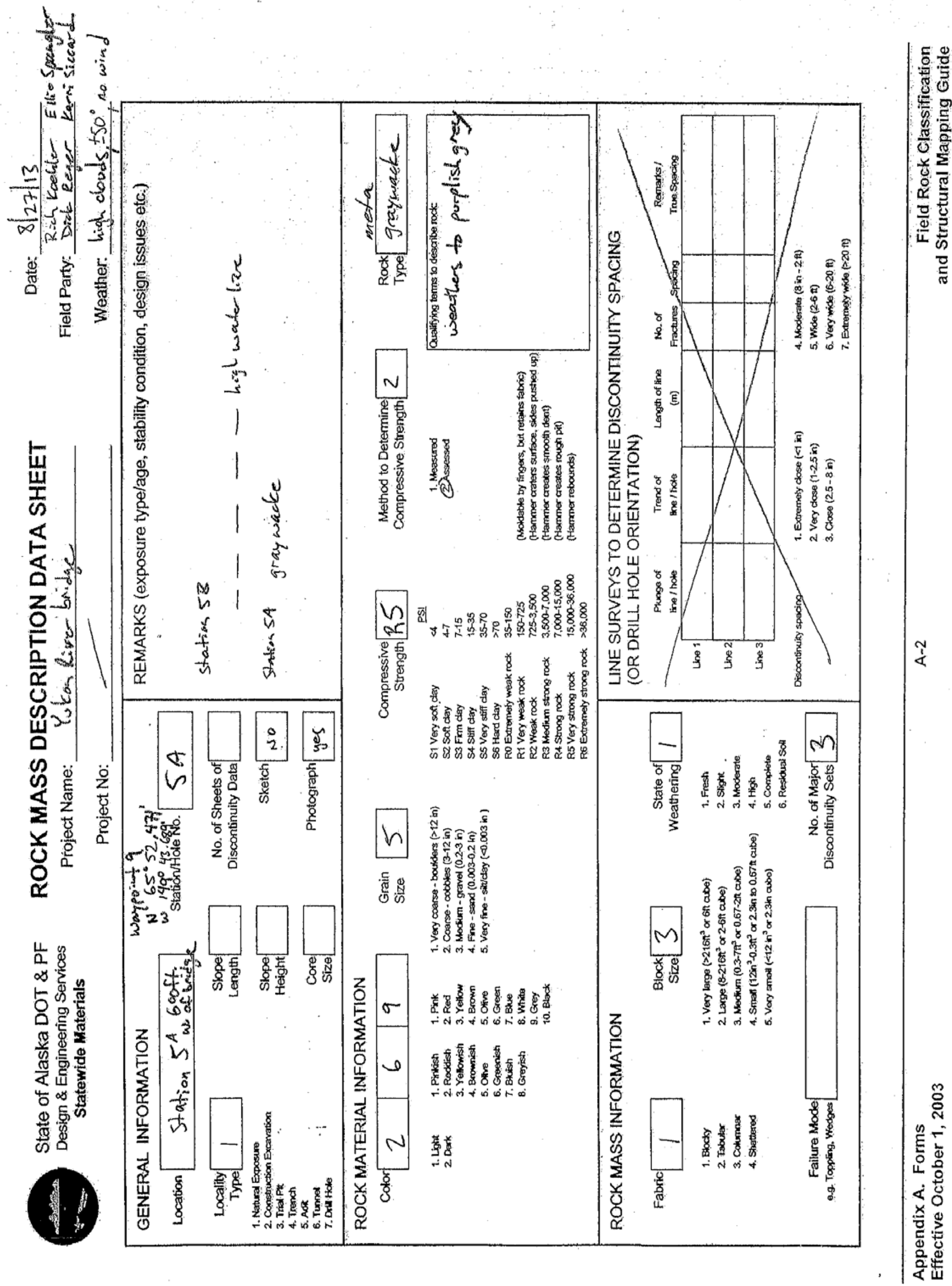


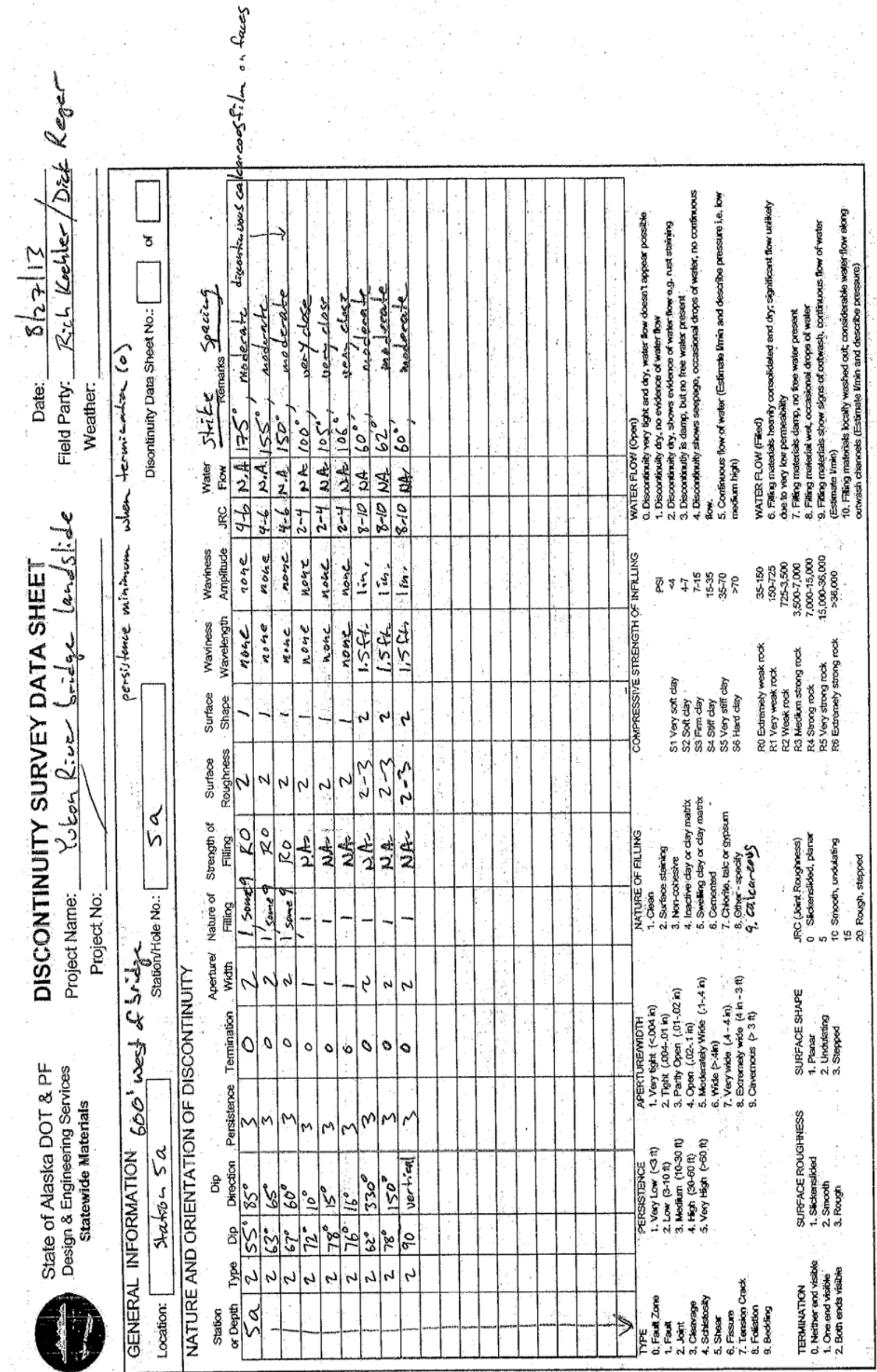

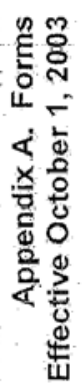




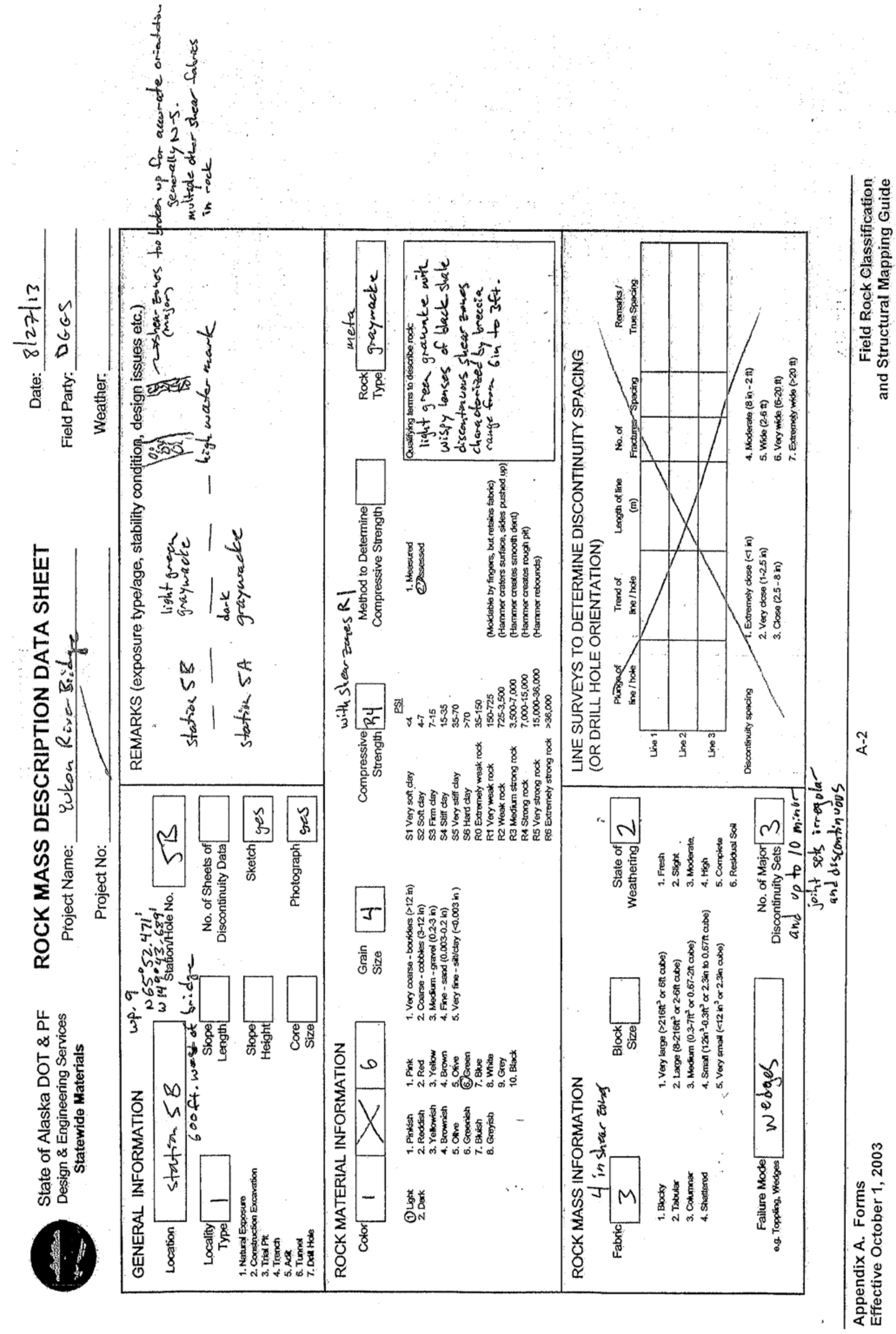




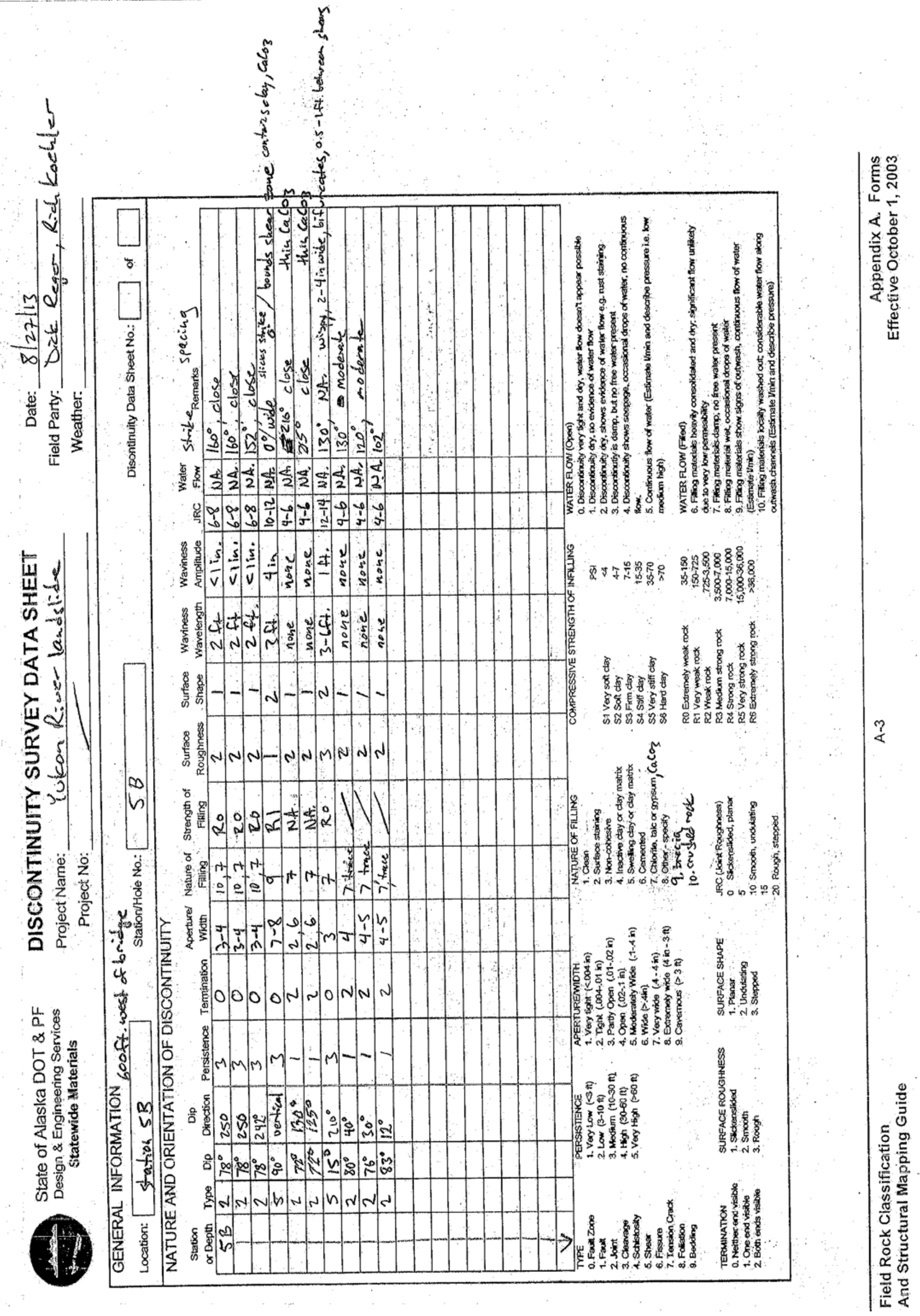




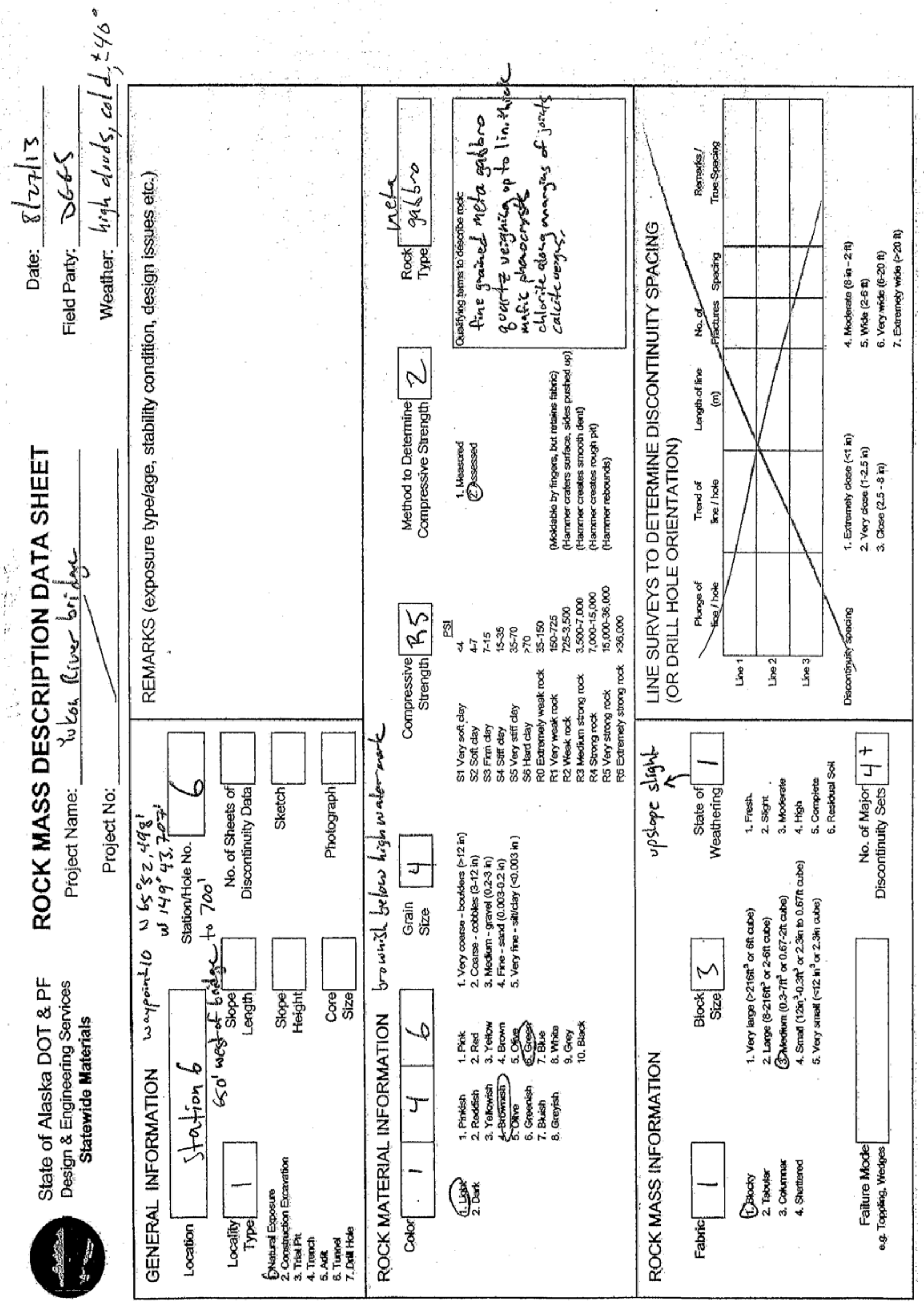




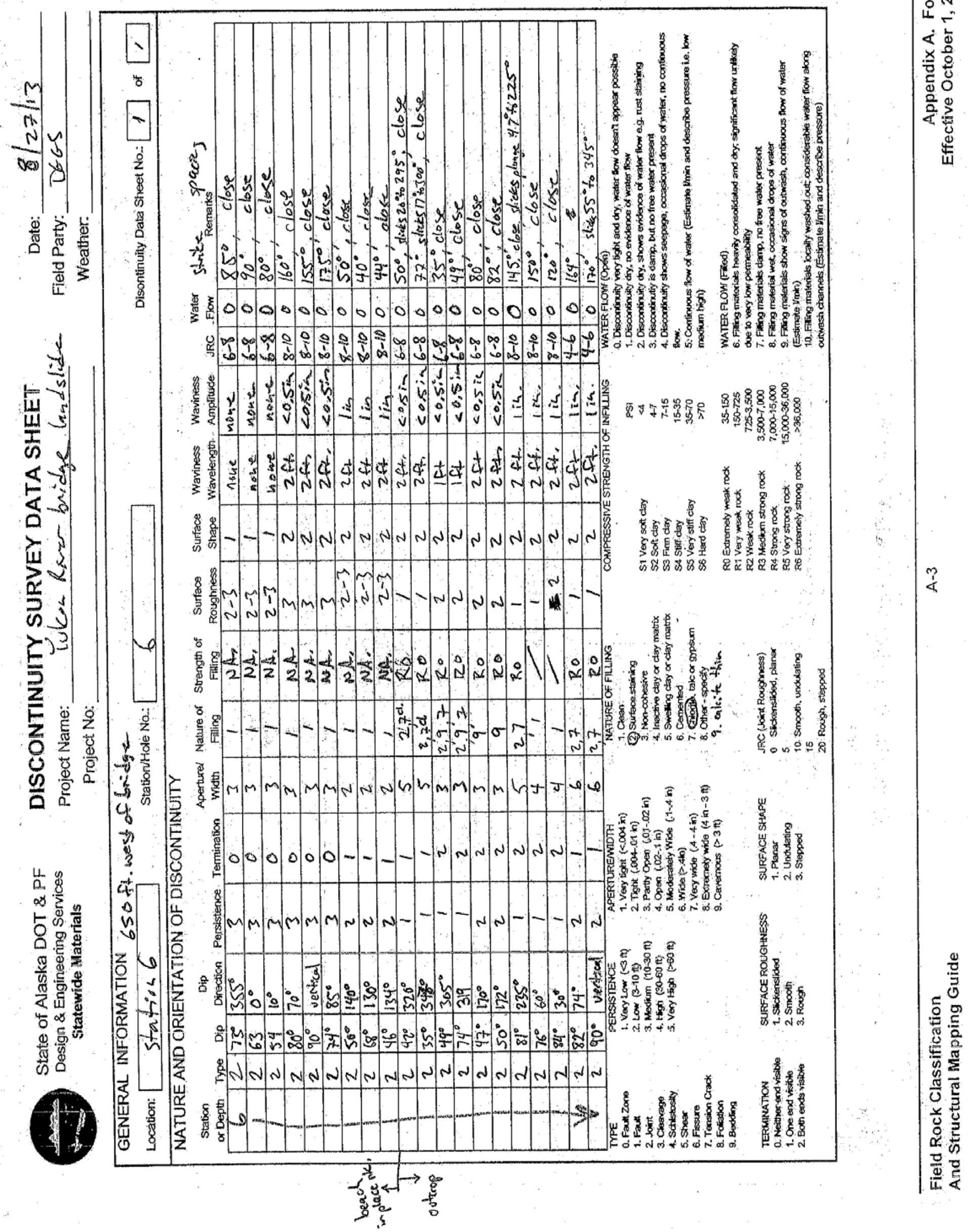




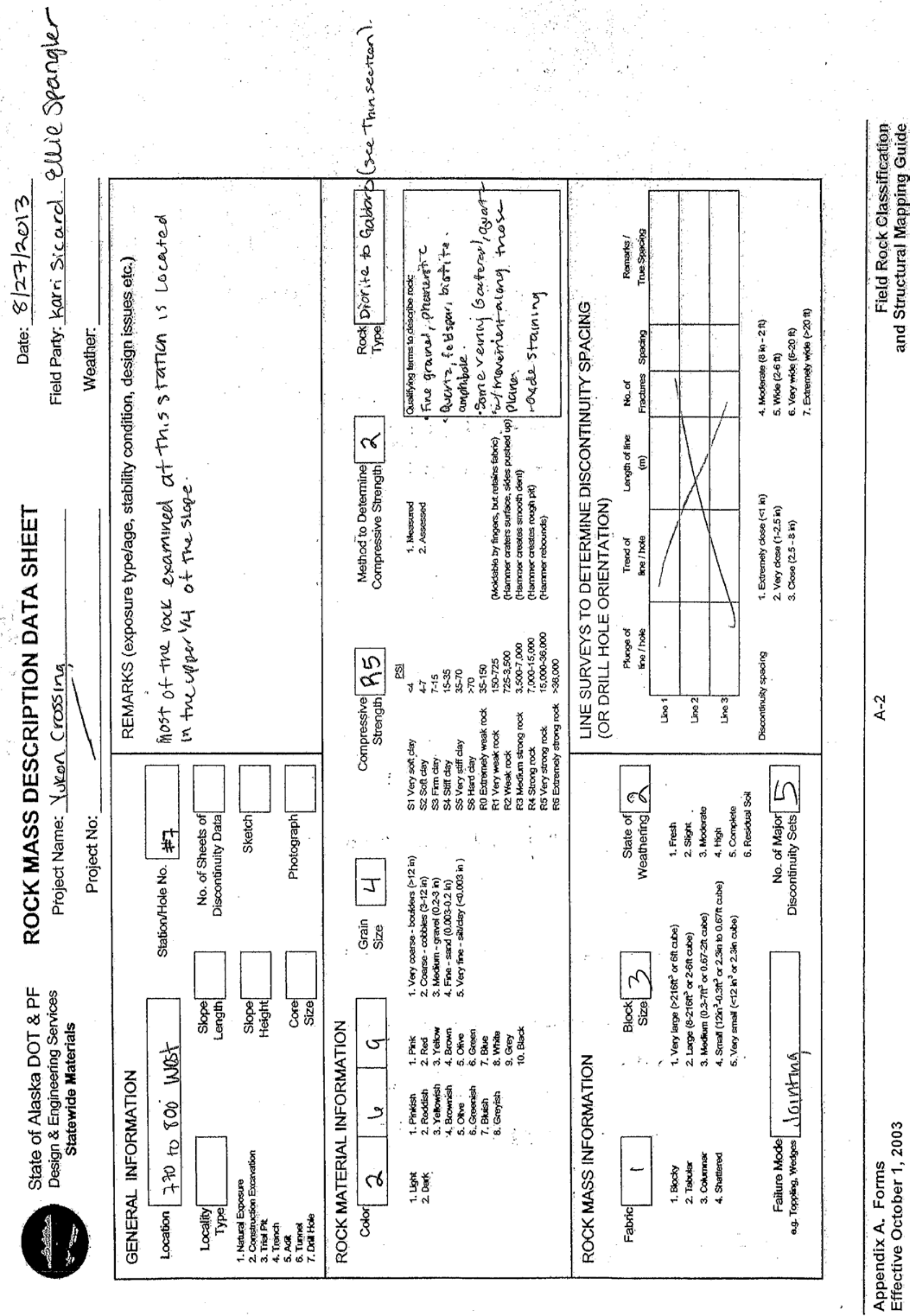




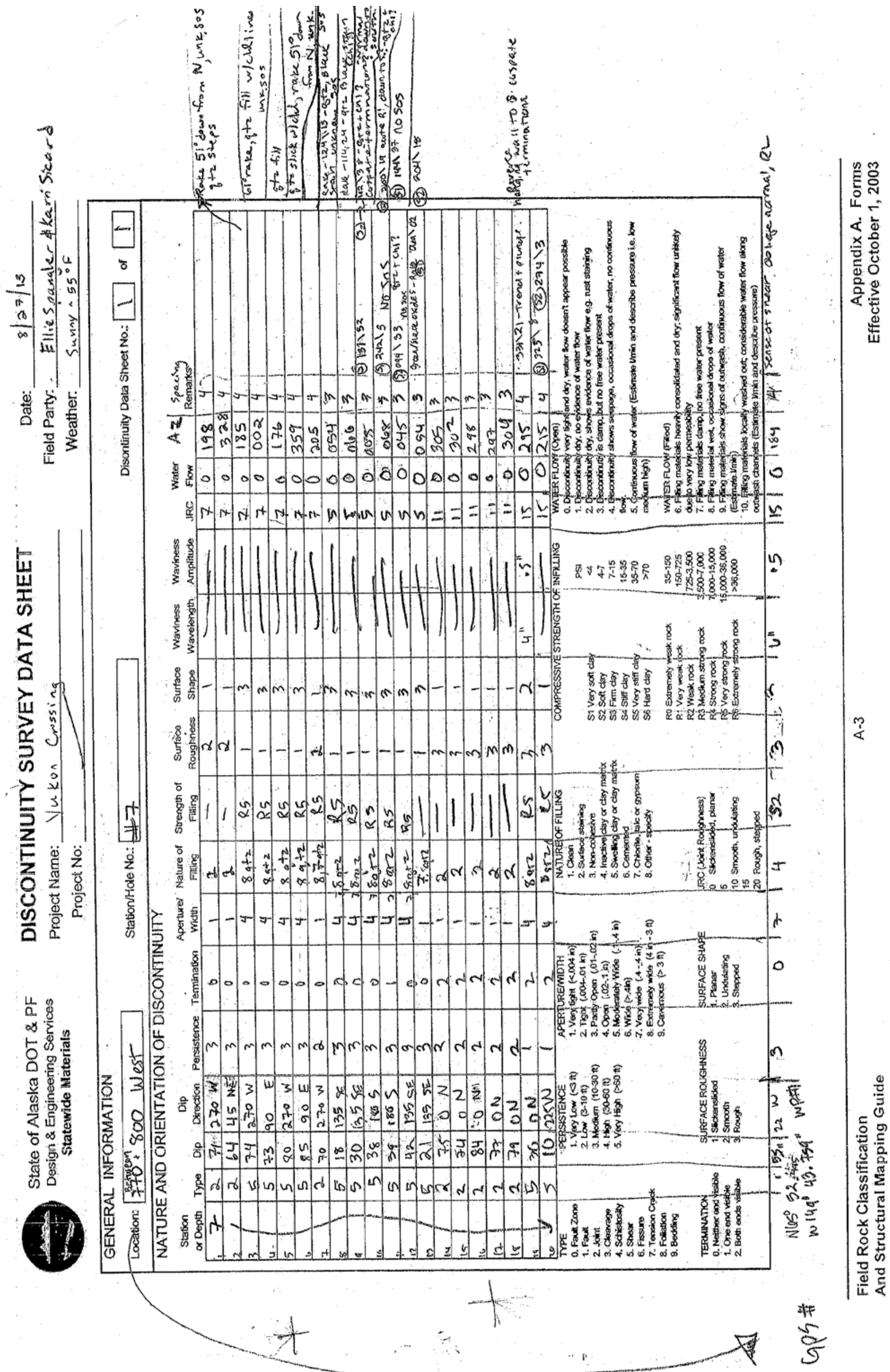




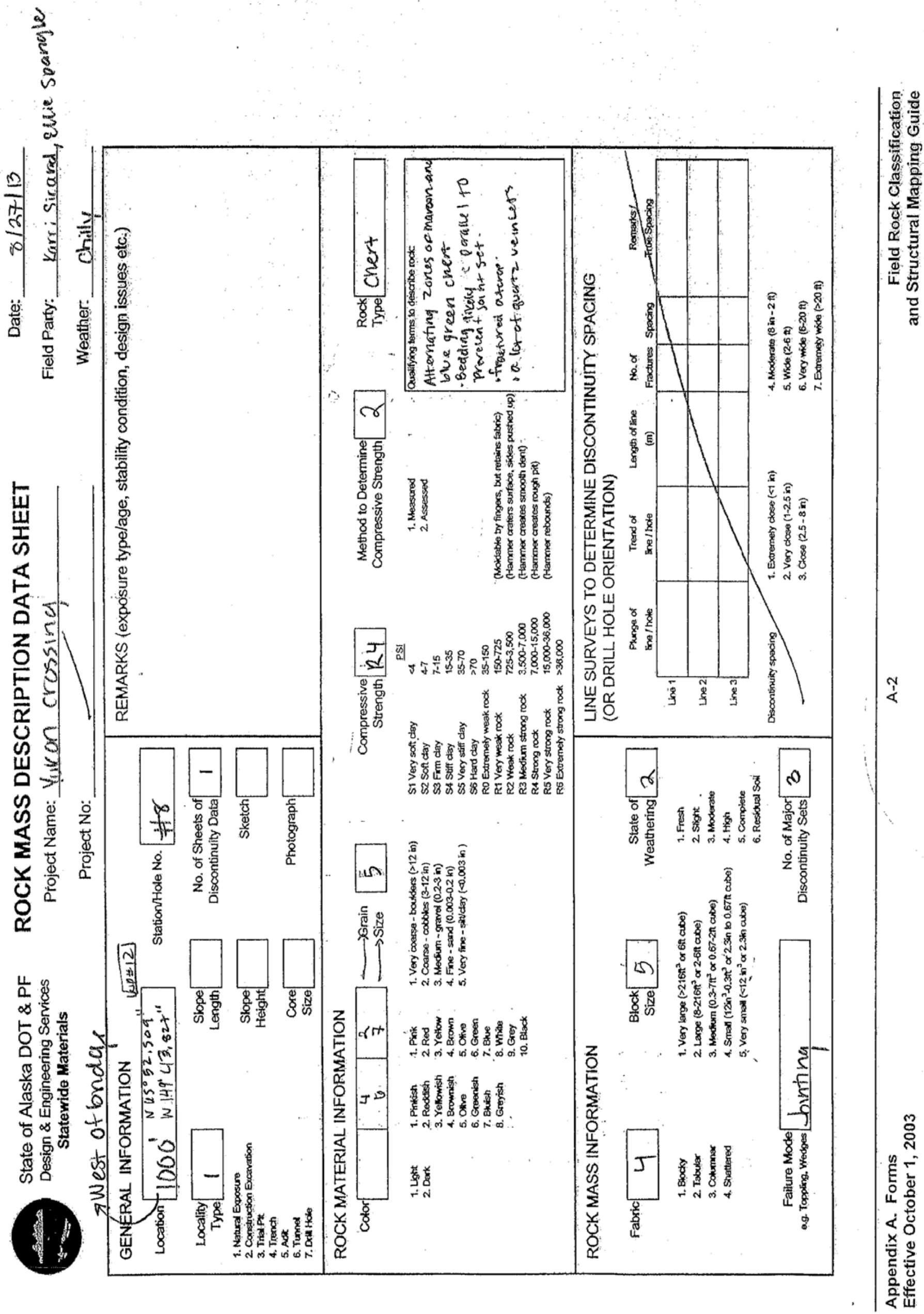




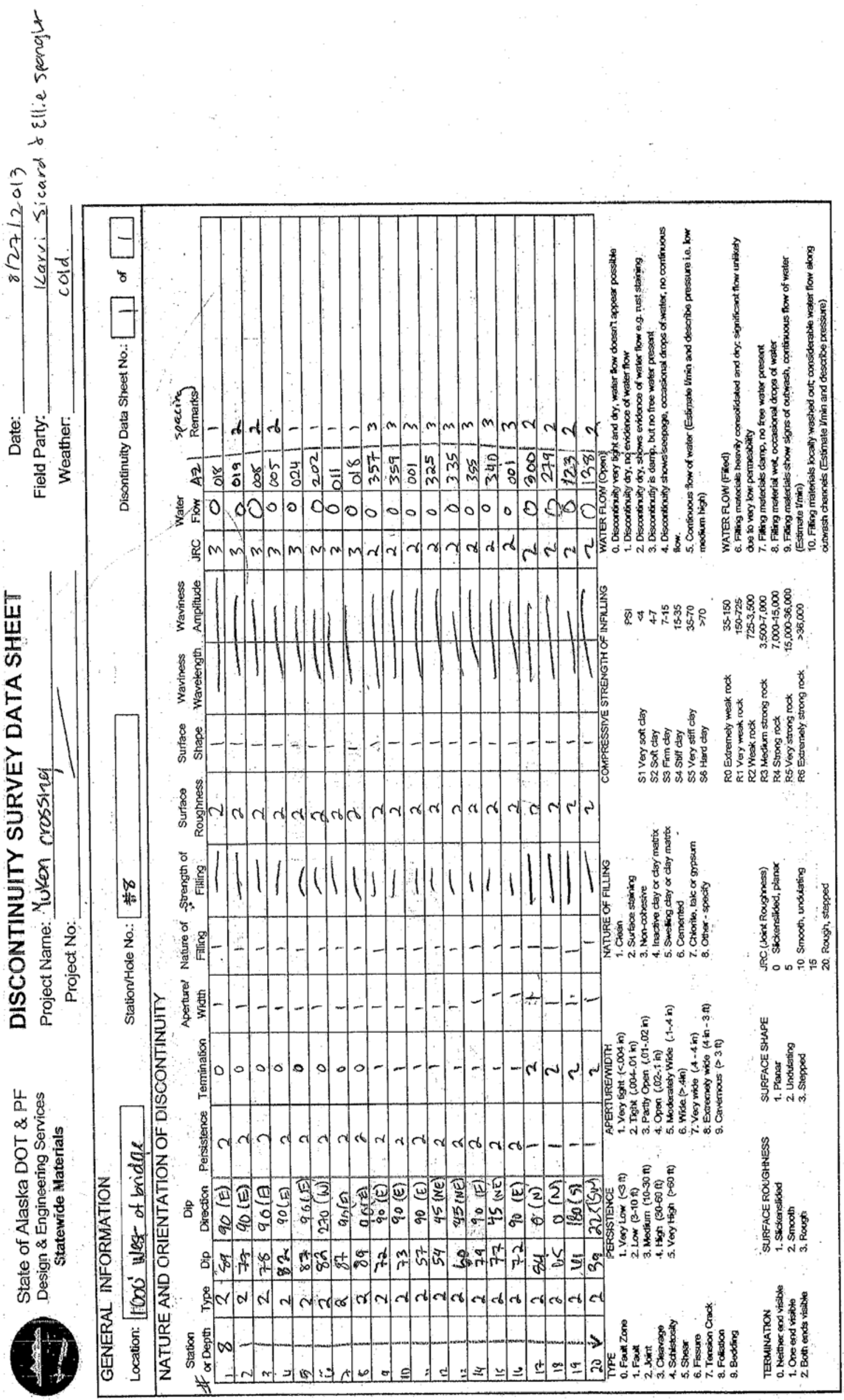




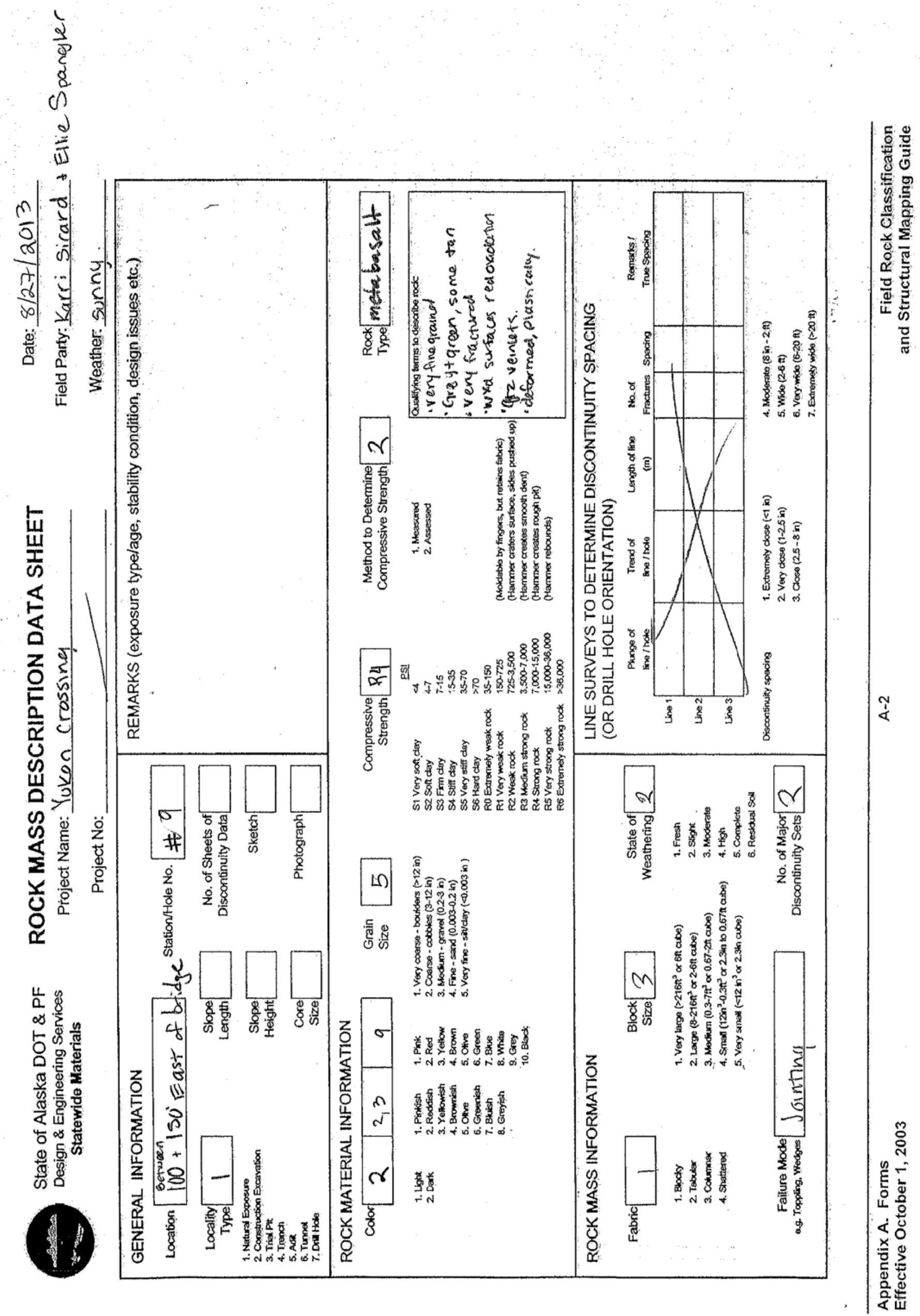


$\frac{5}{5}$

.

$\xi$
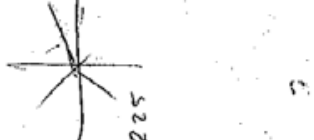

8

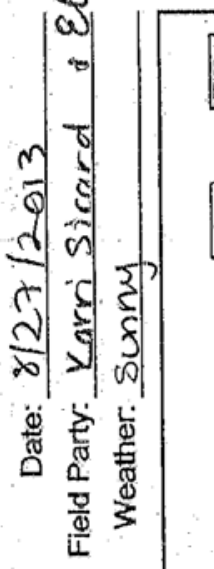

.

.

mo

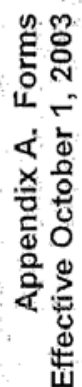

:

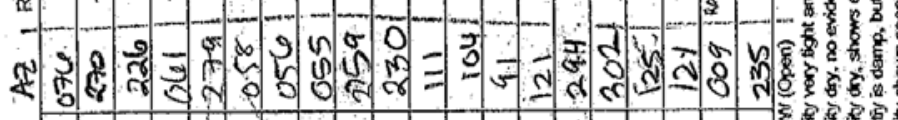

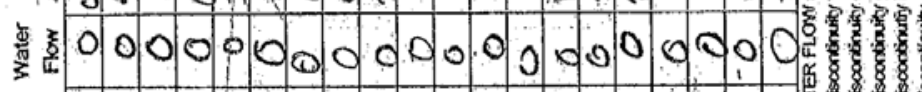

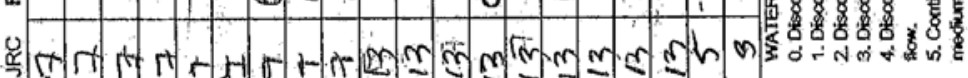

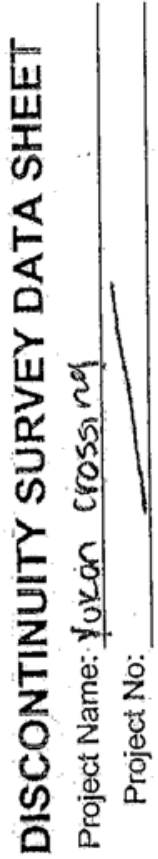

案

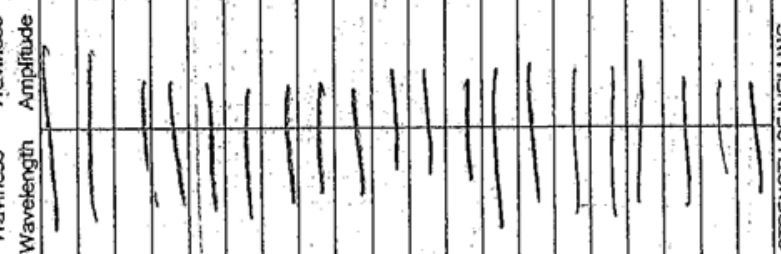

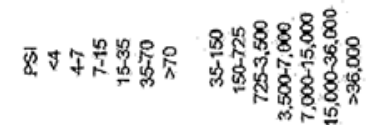

$\frac{8}{2}-$

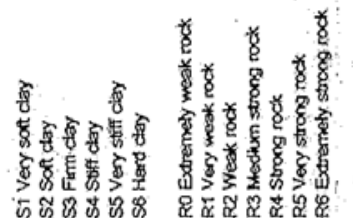

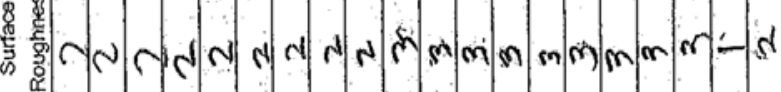

$\stackrel{?}{4}$ "

留

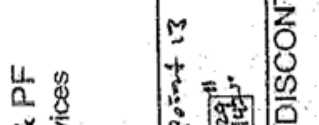

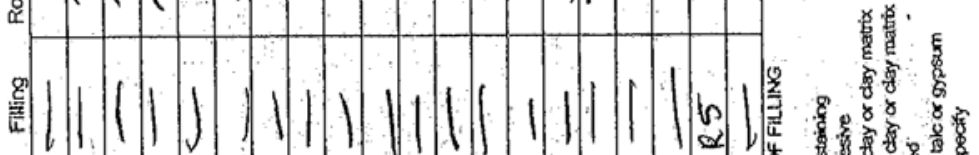

.

$-1-$

$\triangle 1$

2.

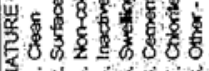

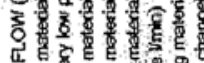

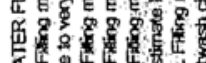

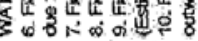

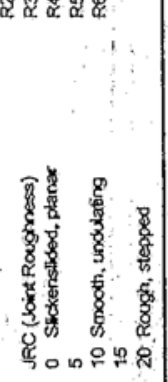

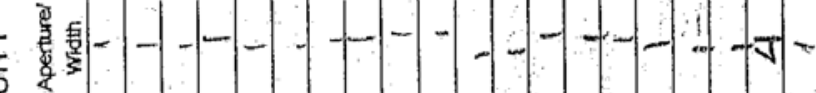

का मैं क्ष

द $\overline{\mathrm{s}}$

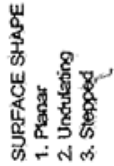

$\infty$ 己

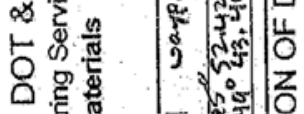

Q

定它

○。

0 点

要需

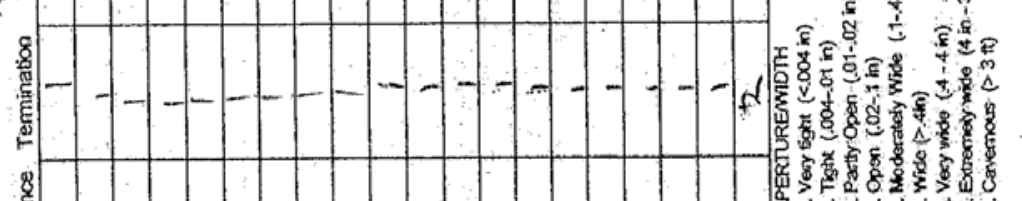

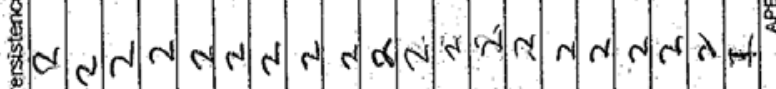

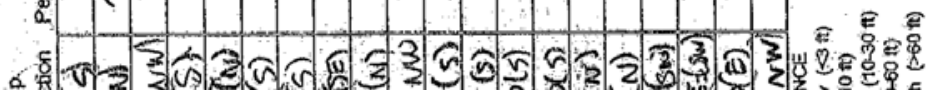

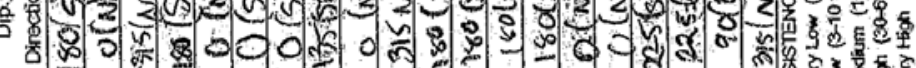

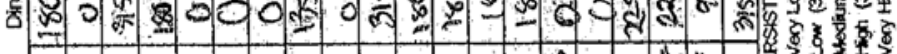

ㅇำ

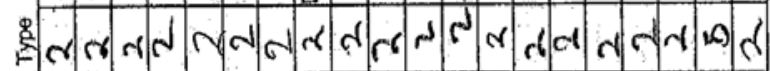

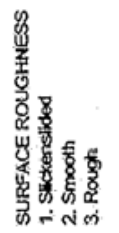




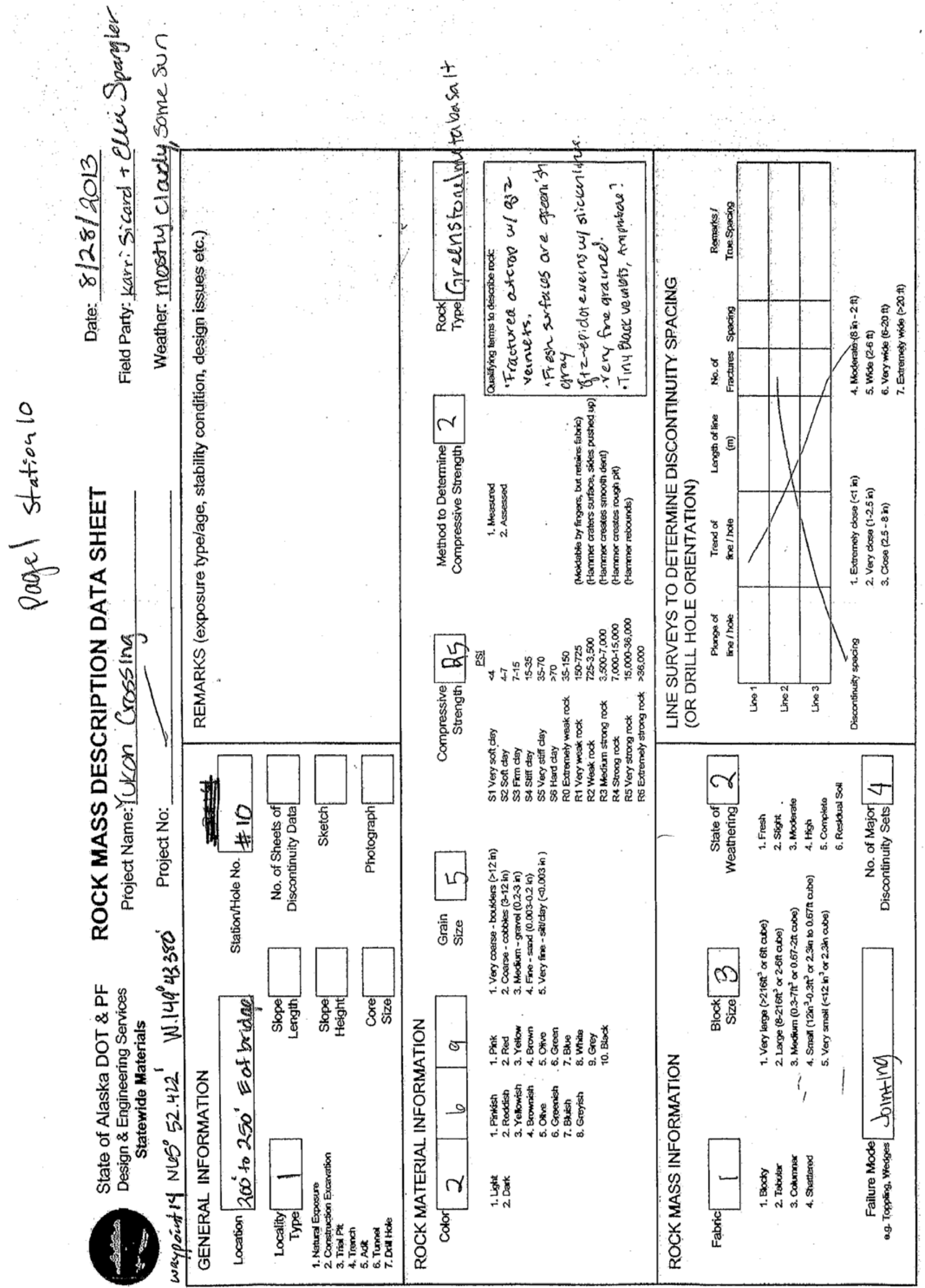




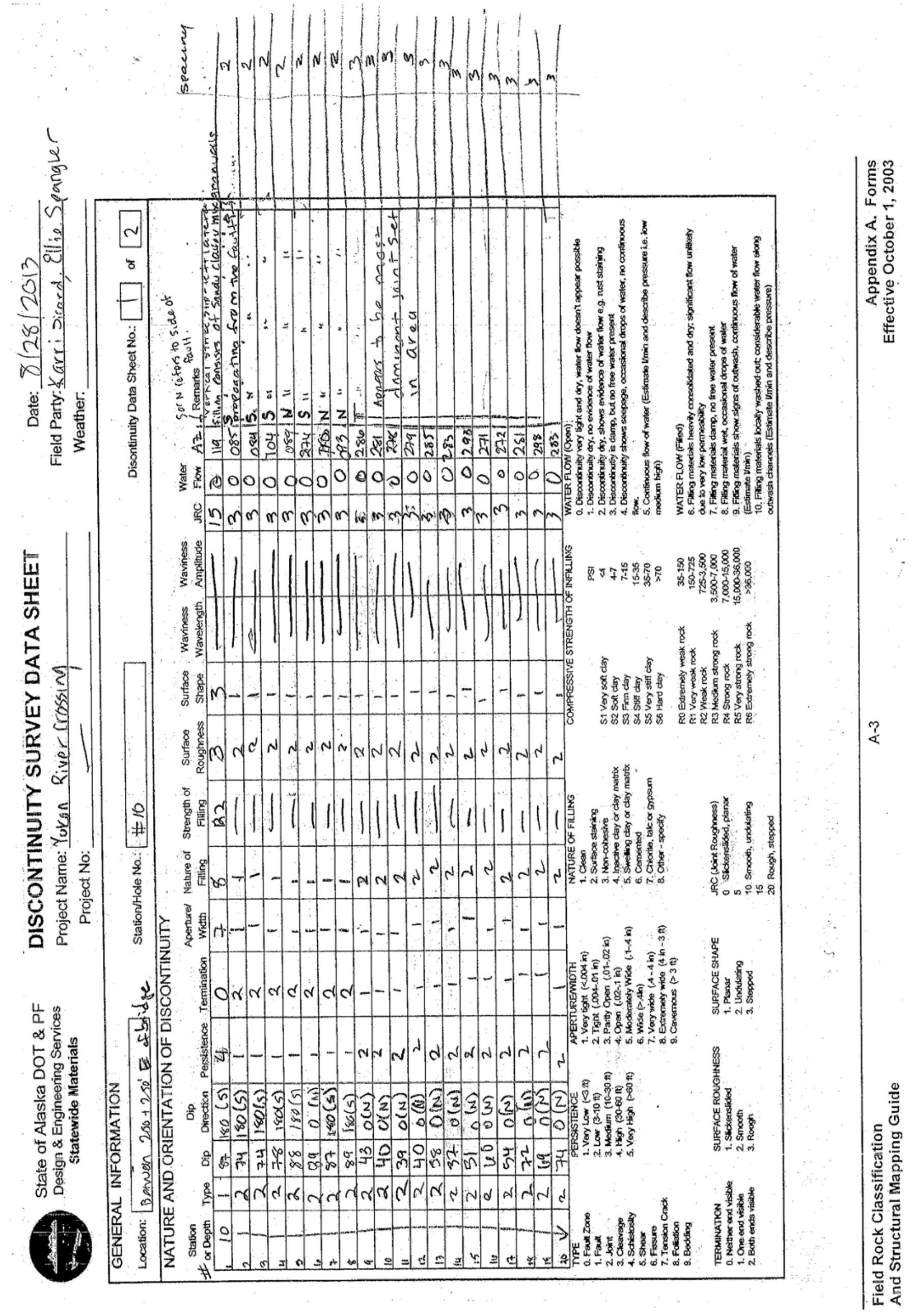




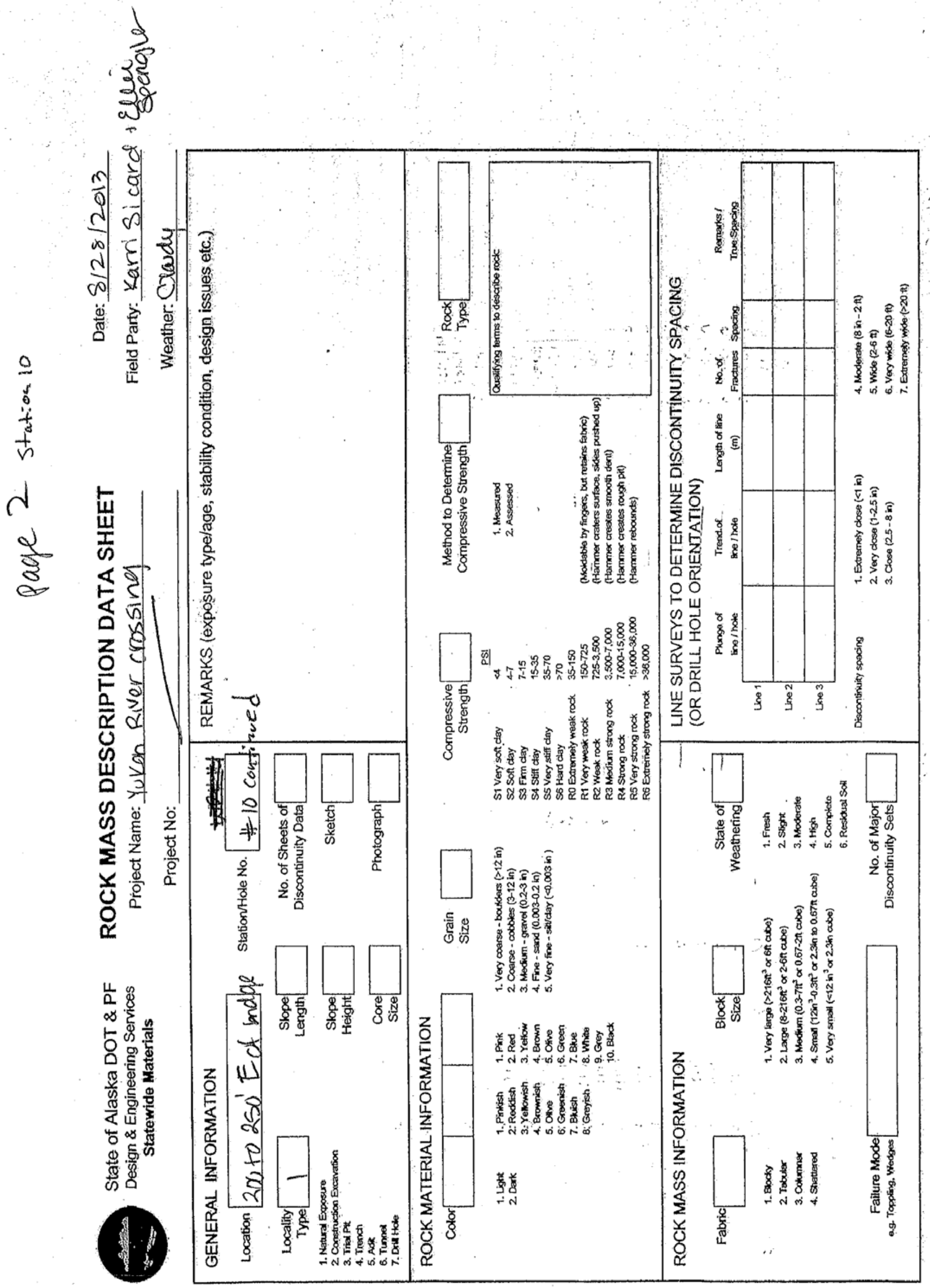








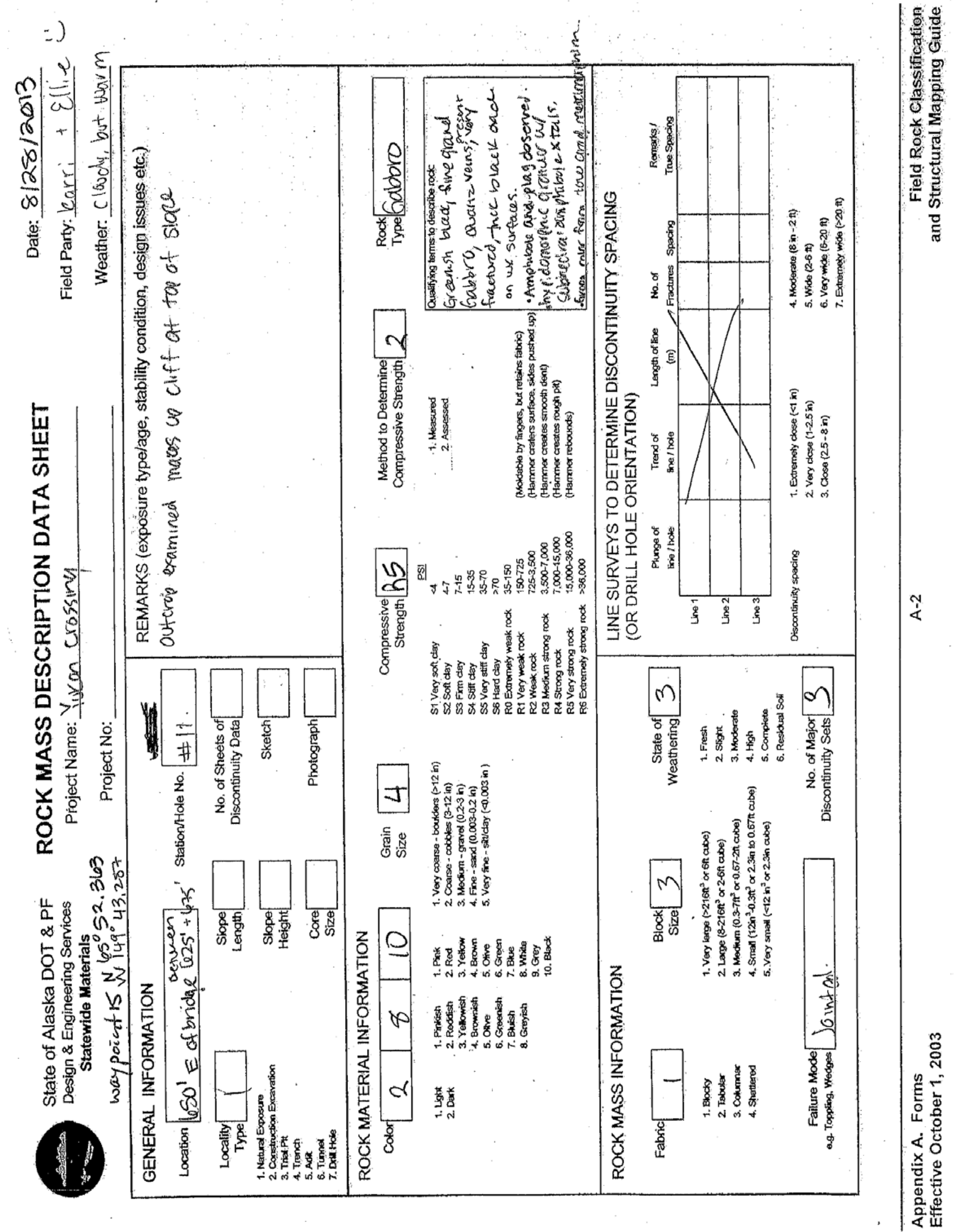

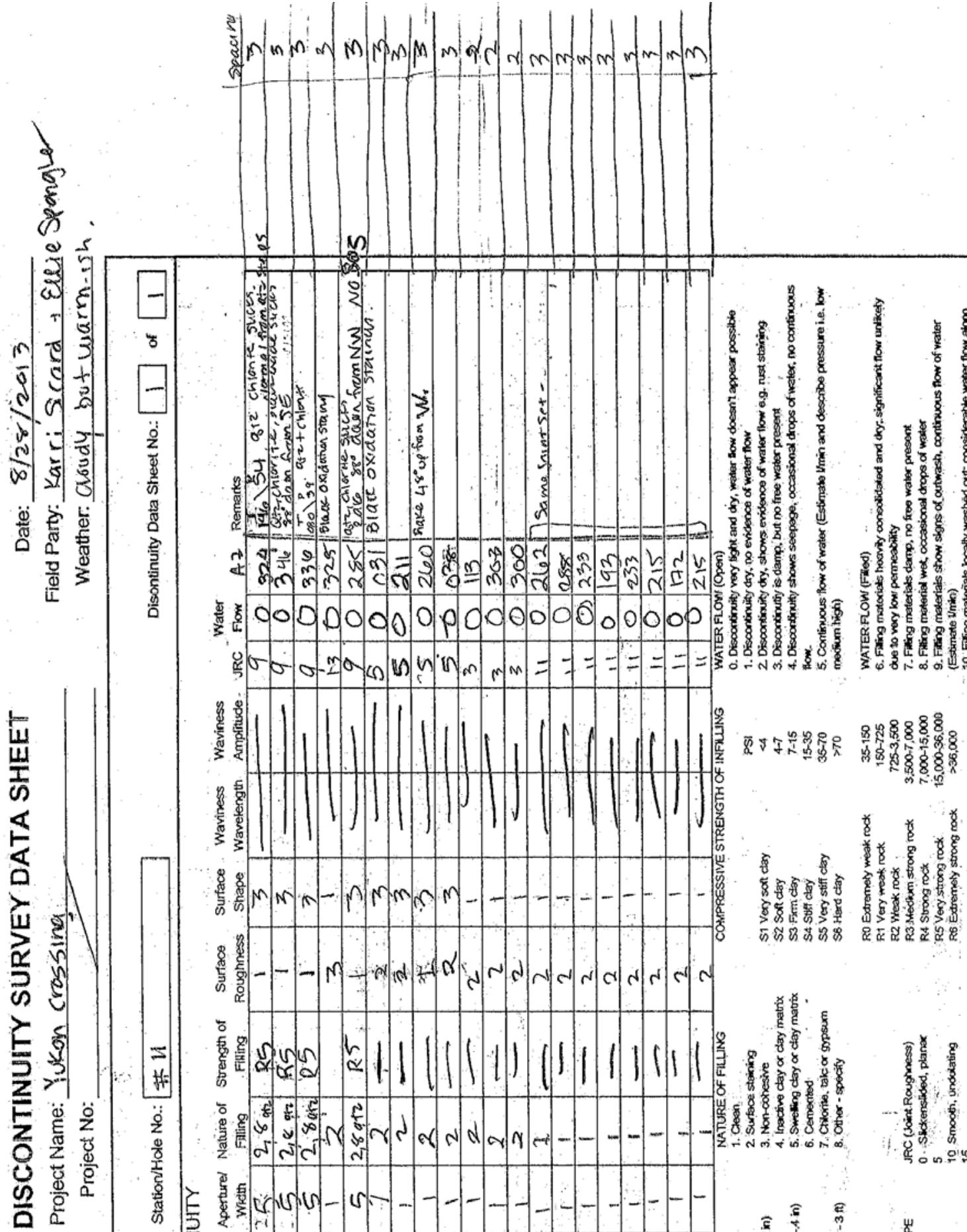

i

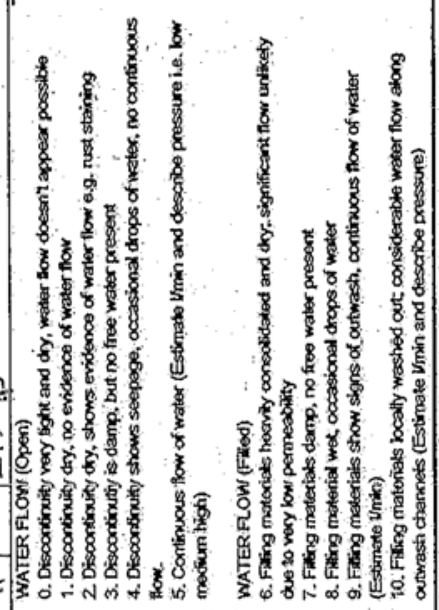

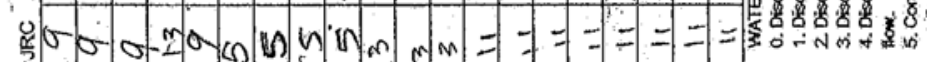

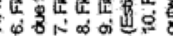

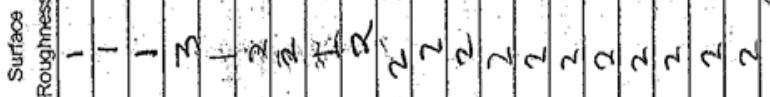

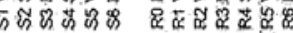

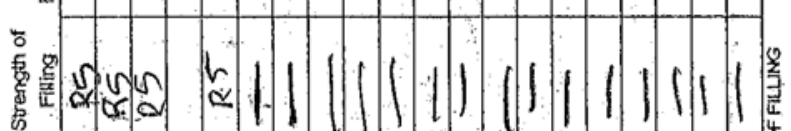

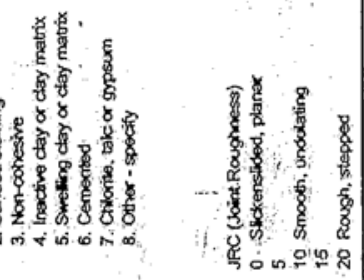

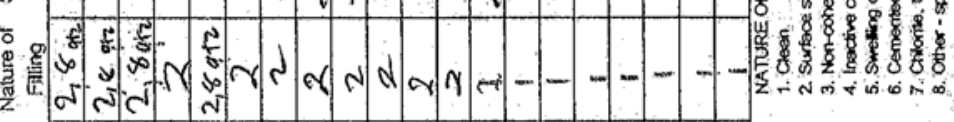

E

窟

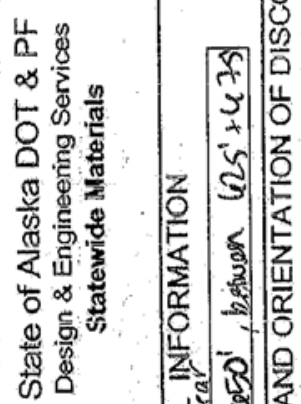

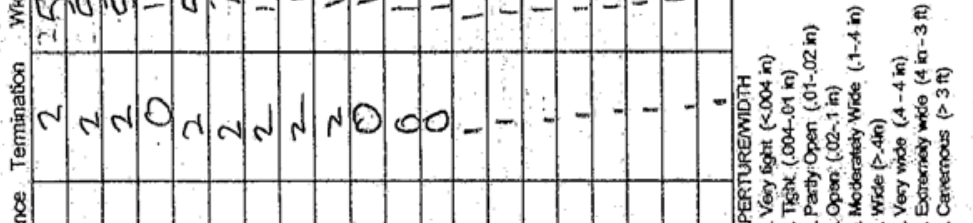

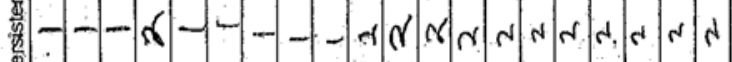

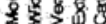

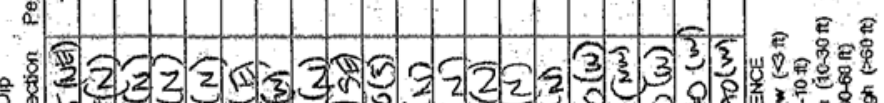

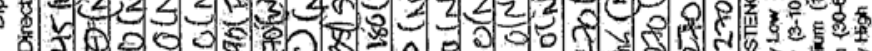

-

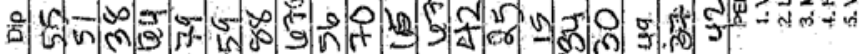

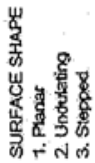



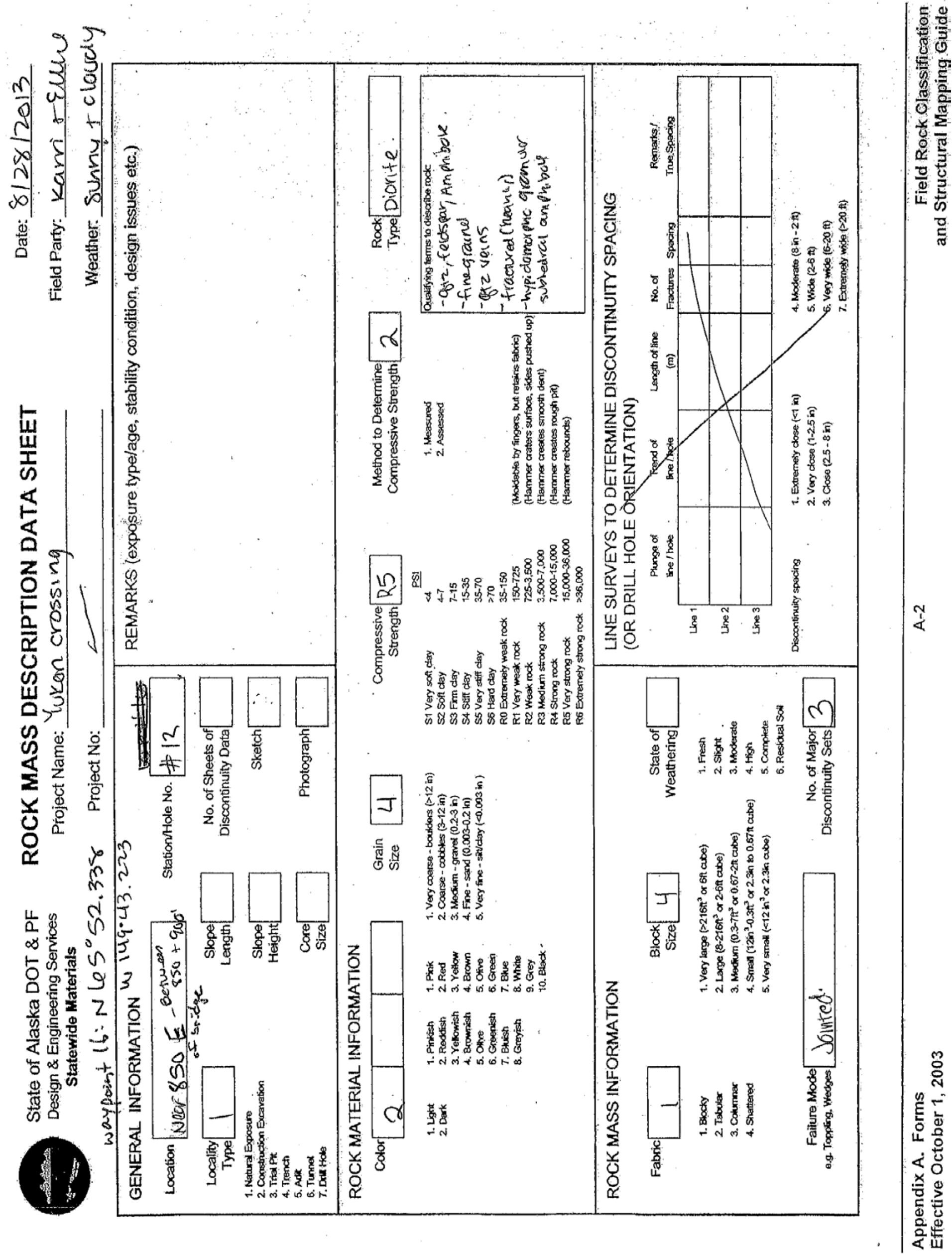

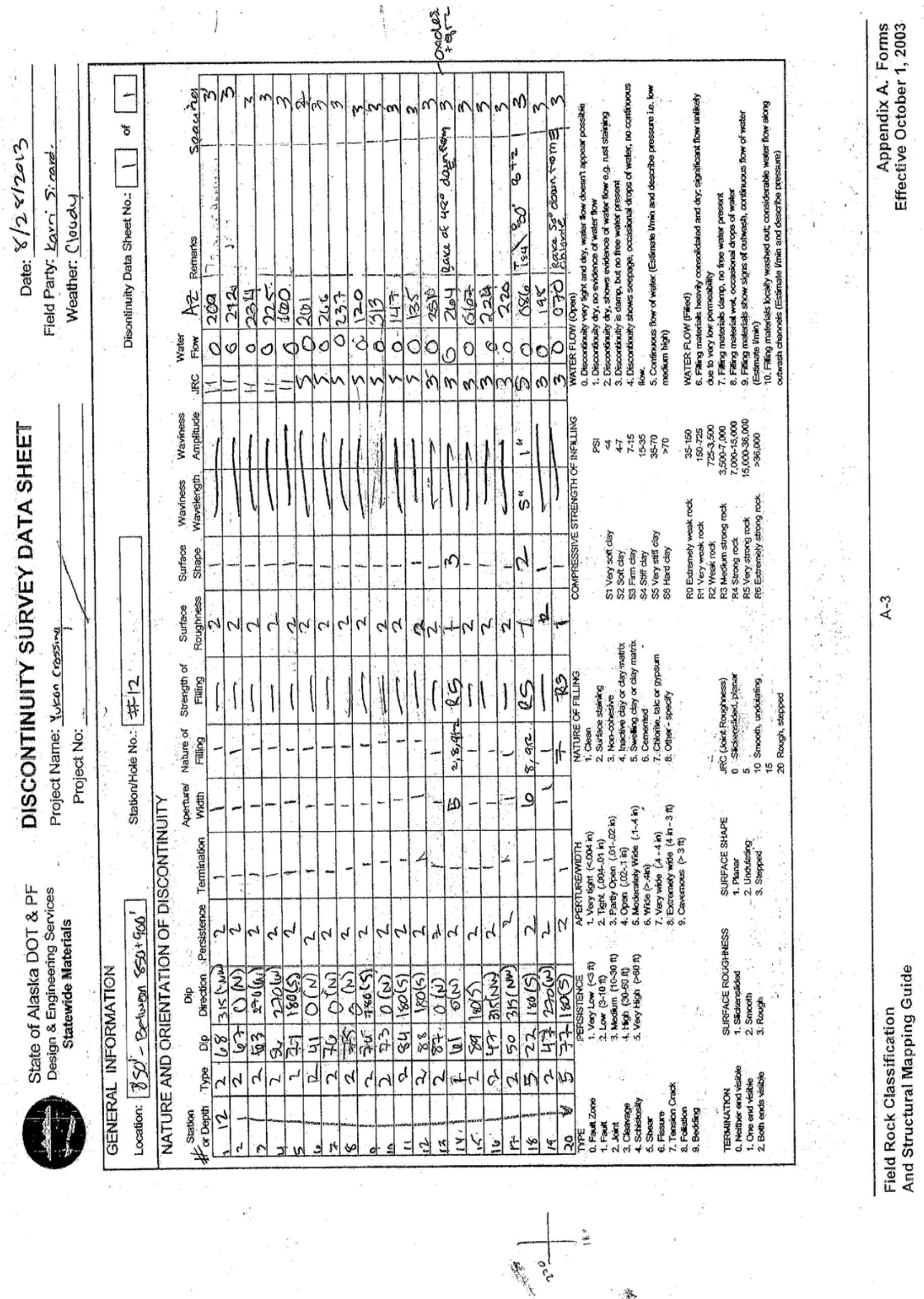


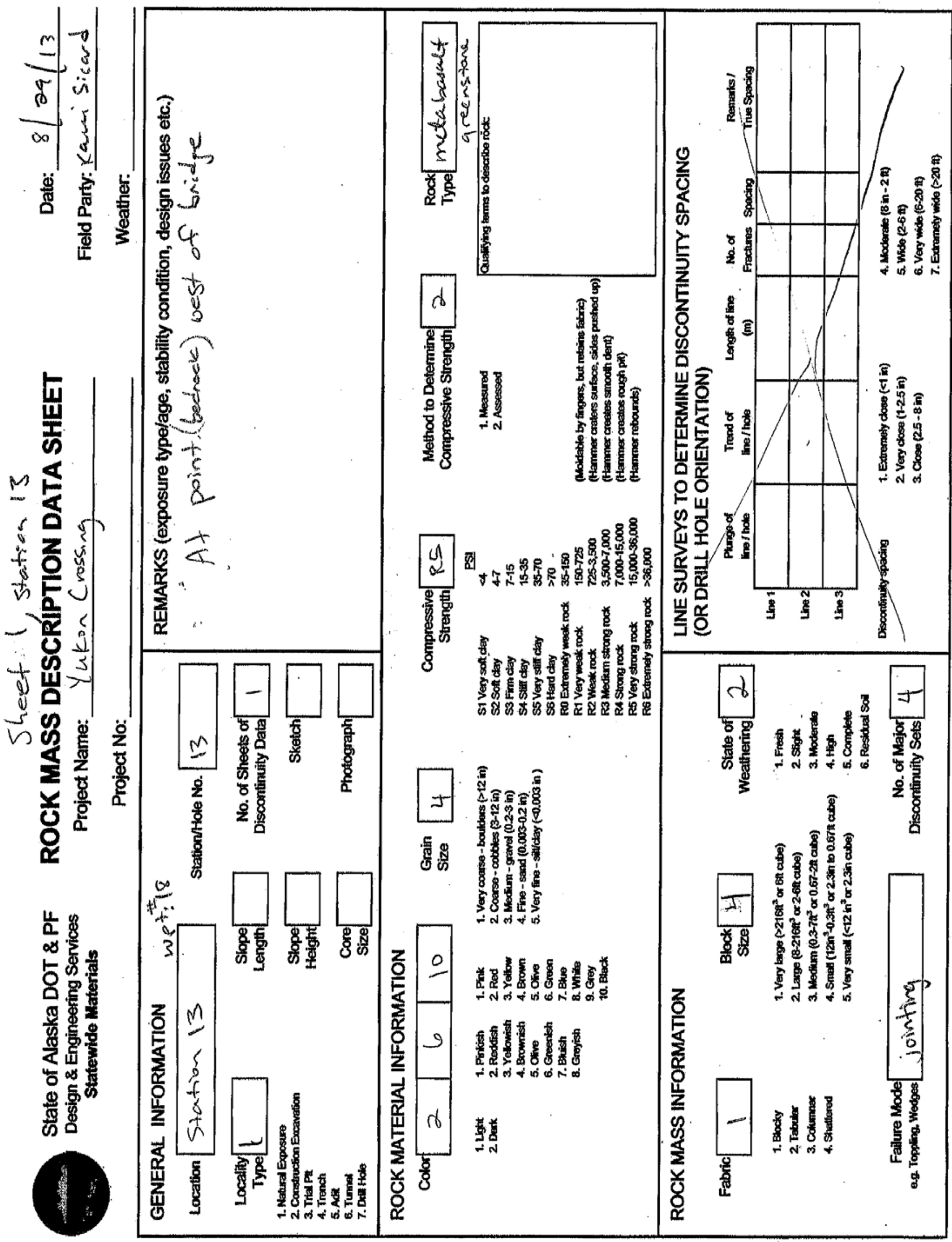




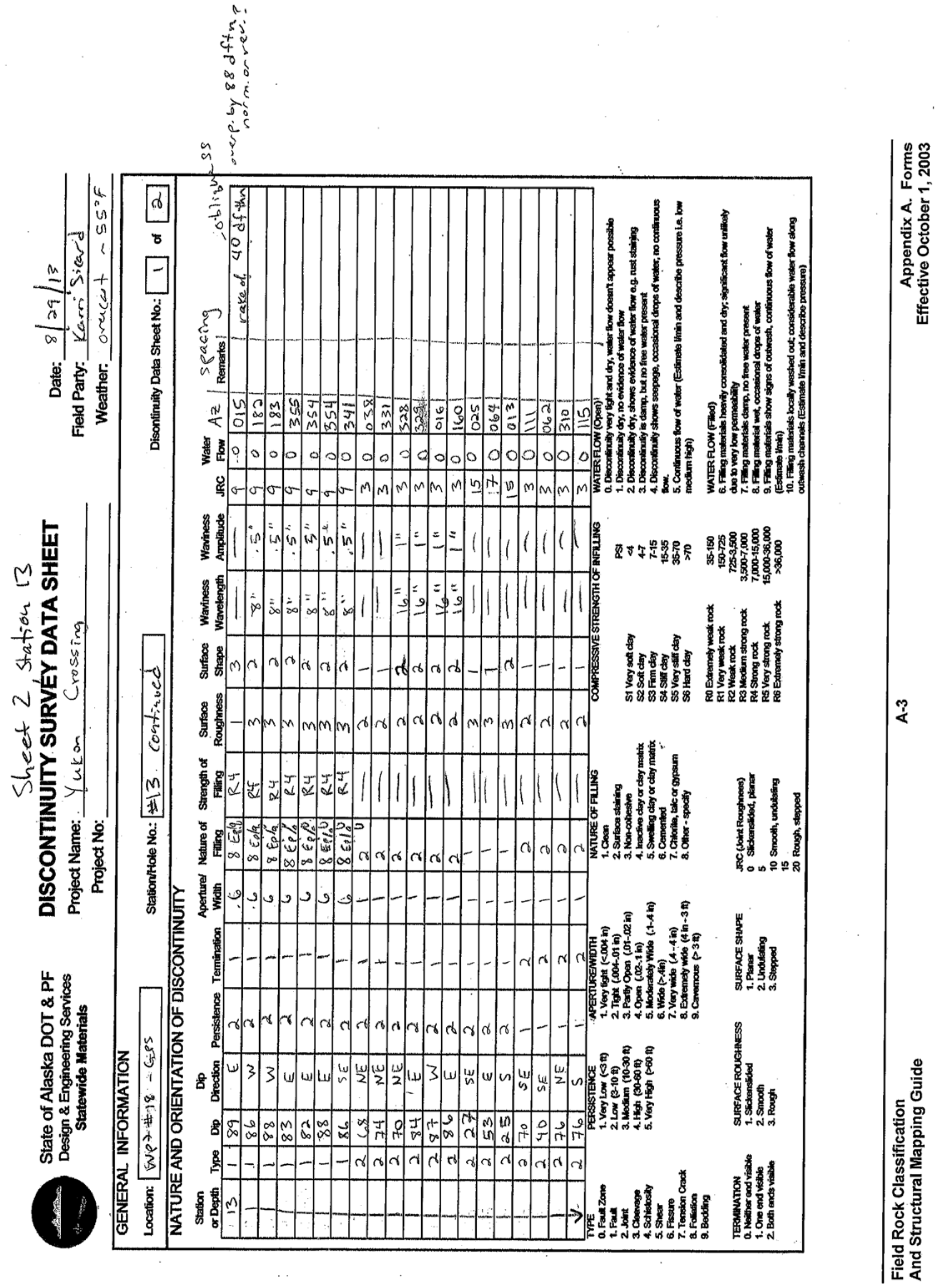



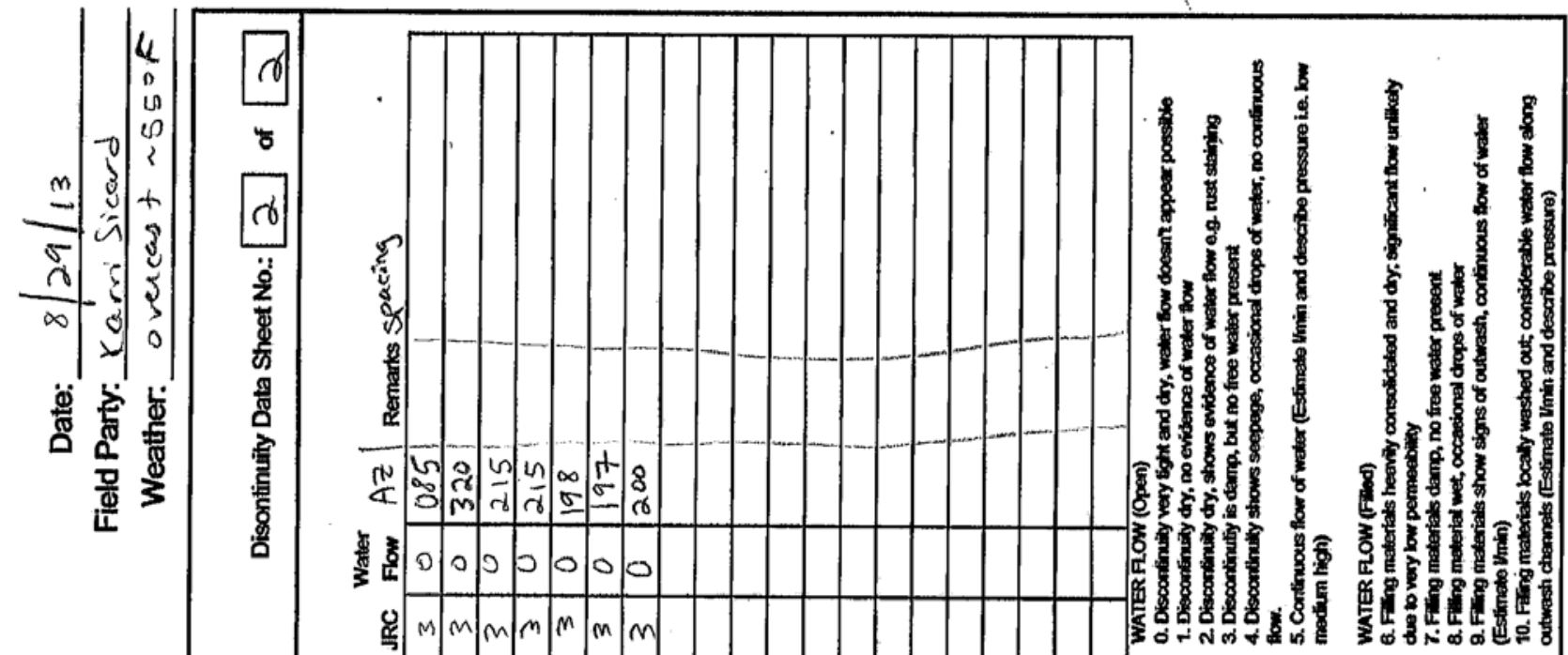

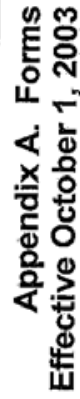
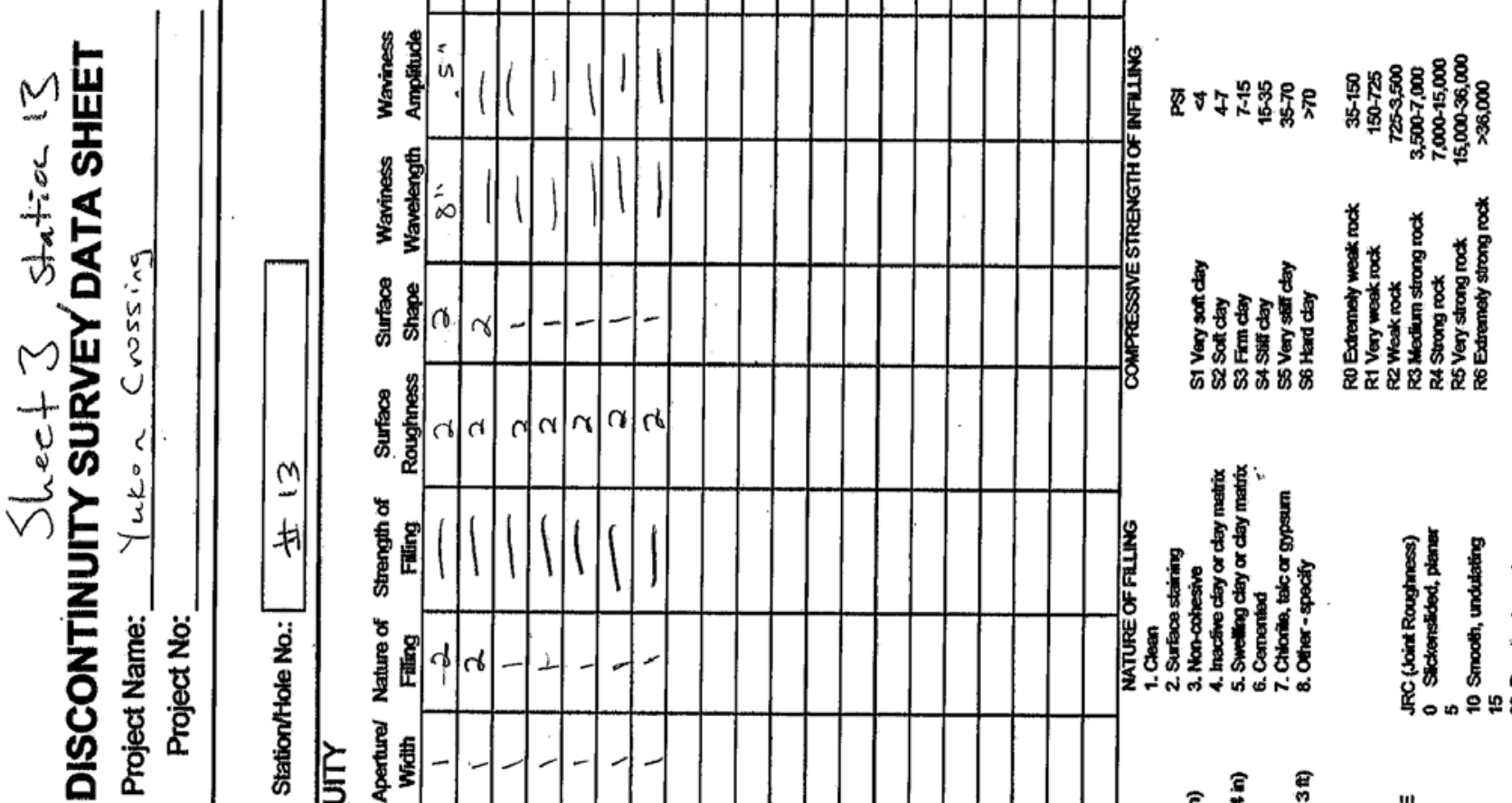

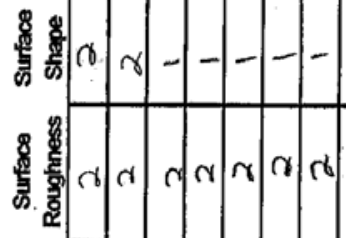

$\stackrel{m}{4}$

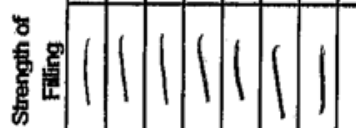

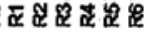

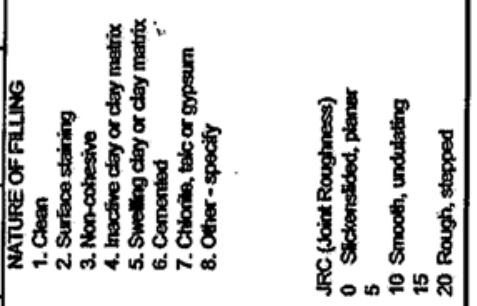

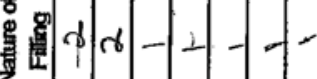

$\frac{2}{5}-1-1-1-$

ลำ

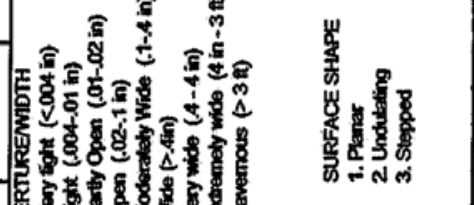

岇 量

占密

号罾

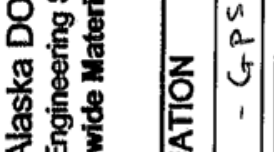

४

点然

营安

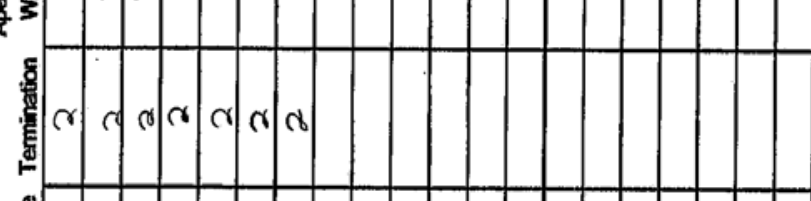

.

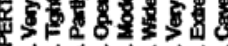

焉

:-1- - -

उ

$\begin{array}{llllll}0 & 0 \\ 0\end{array}$

س

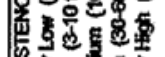

$8 \infty \ln (\infty) \infty$

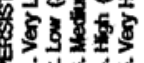

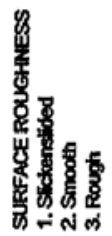

